\title{
WestVirginiaUniversity
}

THE RESEARCH REPOSITORY @ WVU

Graduate Theses, Dissertations, and Problem Reports

2014

\section{Factors that influence clinical placements for teacher candidates}

Kristi M. James

West Virginia University

Follow this and additional works at: https://researchrepository.wvu.edu/etd

\section{Recommended Citation}

James, Kristi M., "Factors that influence clinical placements for teacher candidates" (2014). Graduate Theses, Dissertations, and Problem Reports. 249.

https://researchrepository.wvu.edu/etd/249

This Dissertation is protected by copyright and/or related rights. It has been brought to you by the The Research Repository @ WVU with permission from the rights-holder(s). You are free to use this Dissertation in any way that is permitted by the copyright and related rights legislation that applies to your use. For other uses you must obtain permission from the rights-holder(s) directly, unless additional rights are indicated by a Creative Commons license in the record and/ or on the work itself. This Dissertation has been accepted for inclusion in WVU Graduate Theses, Dissertations, and Problem Reports collection by an authorized administrator of The Research Repository @ WVU.

For more information, please contact researchrepository@mail.wvu.edu. 


\title{
Factors that influence clinical placements for teacher candidates
}

\author{
Kristi M. James
}

Dissertation submitted to the College of Education and Human Services

At West Virginia University

In partial fulfillment of the requirements for the Degree of

Doctor of Education

In

Educational Leadership Studies, Higher Education Administration

\author{
Dr. Joy Faini Saab, Chair \\ Dr. Elizabeth Dooley \\ Dr. Michael Cunningham \\ Dr. Samuel Stack \\ Dr. Nathan Sorber \\ Department of Curriculum \& Instruction/ Literacy Studies \\ Morgantown, WV \\ 2014 \\ Keywords: Clinical experience, cooperating teachers, teacher candidates
}

Copyright 2014 - Kristi M. James 


\section{ABSTRACT \\ Factors that influence clinical placements for teacher candidates}

\section{Kristi M. James}

In 2010, President Barack Obama's administration committed to reevaluate funding streams for No Child Left Behind (NCLB). This effort supported state and local initiatives designed to strengthen teacher quality. While a number of studies have examined preparation programs, candidate efficacy, and even candidate induction and attrition; few studies have sufficiently documented the factors that influence cooperating teachers' decision to mentor teacher candidates. This descriptive study identified in-service teachers' perceptions of the challenges and benefits to mentoring teacher candidates, investigated these perceptions across specific demographic aspects, and school designation (PDS or NON-PDS). Using the Teacher Perceptions questionnaire, the researcher collected data from in-service teachers. In addition to exploring the challenges and benefits of mentoring teacher candidates from the perspective of inservice teachers, this study also examined the effect of limited clinical placements on teacher preparation programs. Findings from this study indicated that even though the majority of teachers surveyed believe that mentoring teacher candidates is a professional obligation. Even though doing so adds to the already heavy load of classroom teaching. There was no significant relationship between gender, size of institution, level of education, and years of teaching experience. This study provided a snapshot of teacher perceptions in the eastern Mid-Atlantic region of the United States, adds to the available information on teacher candidate placements and clinical experiences, and provides insights for future research. 


\section{DEDICATION}

I dedicate my dissertation work to my Lord and Savior Jesus Christ, my family and my friends. With an unfathomable feeling of gratitude to my loving and adoring mother, JoAnn D. James, her supportive words of encouragement and tenacity kept the fire burning in my heart. She nurtured my inquisitive nature, always stimulated my thirst for learning, and reminded of Philippians 4:13 often. Although they are no longer here, Zachary and Larine Washington, Reverend David Jasper, and Franklin Dreakford never left my side through this process and hold a very special place in my heart. To my friends and church family who have supported me throughout the process, I thank you. I give special thanks to my dearest friends and family members Dr. Kathy Seelinger, Dr. Monica Brooks, LaShara Hoskins, Kirsty Orih, Dr. Angela Oglesby, Leon and Phyllis Pilewski, William and Brenda Jackson, James and Joyce Griffin and my wonderful cousin Shelia Washington for being there for me throughout the entire doctoral process. I appreciate all of your cheerleading, talking me off the edge, and listening to my grumbles, and I thank you for not allowing me to wallow in dark places and always pointing my eyes upward. 


\section{ACKNOWLEDGEMENTS}

I thank my committee members who were more than generous with their expertise and precious time. A special thanks to Dr. Joy Faini Saab and Dr. Michael Cunningham. Dr. Saab you took on the responsibility of becoming my chair after considerable difficulty, and restored

my faith in this process. As my committee chairperson you spent hours of reflecting, reading, encouraging, and I thank you most of all for your patience and support throughout the process. Dr. Cunningham, thank you for your time and help. I appreciate your support and encouragement even before you committed to committee work, thank you. Thank you, Dr. Samuel Stack, Dr. Nathan Sorber, and Dr. Elizabeth Dooley for serving on my committee. I acknowledge and thank the College of Education and Professional Development for allowing me to conduct my research and providing any assistance requested. Finally, I would like to thank the teachers and administrators in our school districts that participated in this project. Their excitement and willingness to provide feedback made the completion of this research an enjoyable experience. 


\section{TABLE OF CONTENTS}

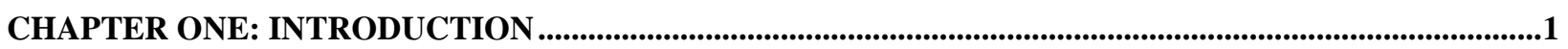

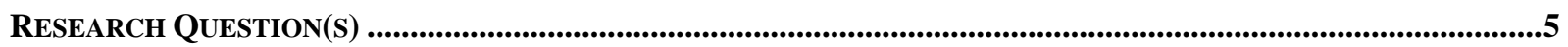

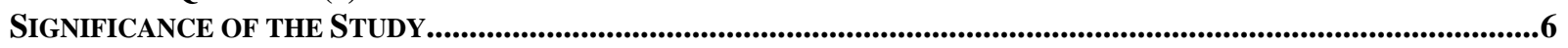

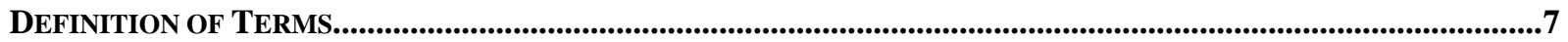

CHAPTER TWO: REVIEW OF LITERATURE ......................................................................................................9

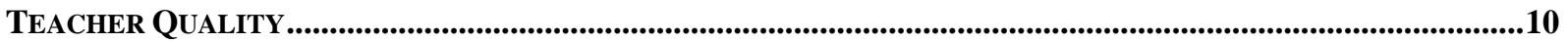

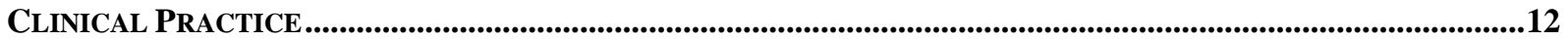

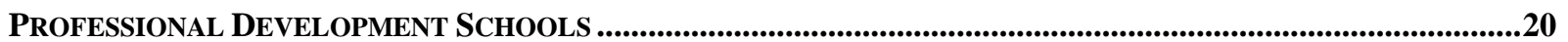

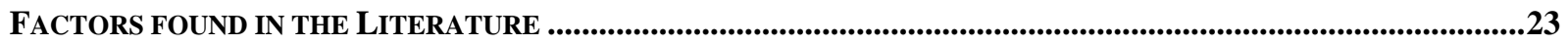

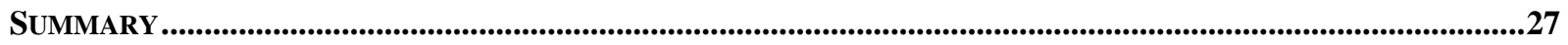

CHAPTER THREE: RESEARCH METHODS .............................................................................................................29

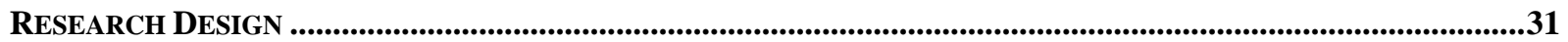

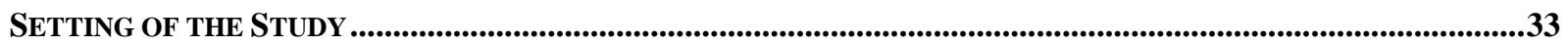

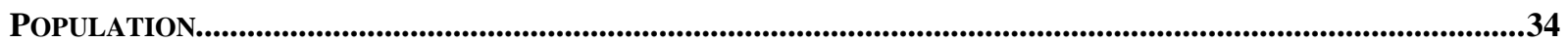

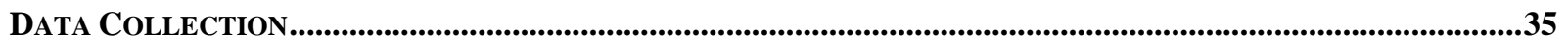

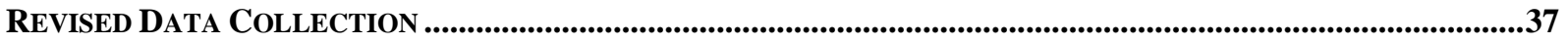

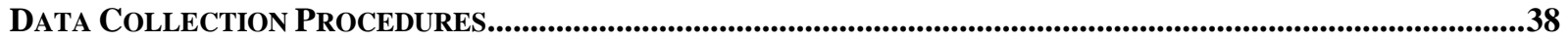

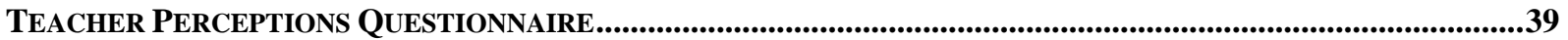

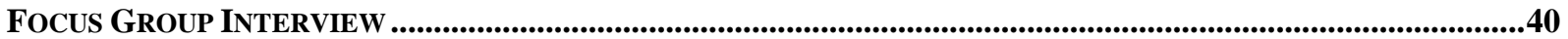

INSTRUMENTATION

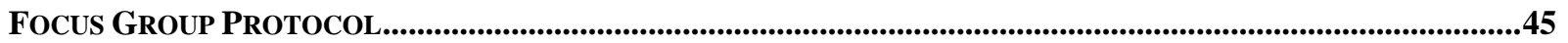

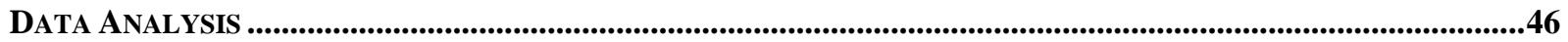

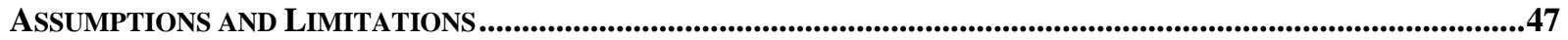

RELIABILITY AND VALIDITY ..................................................................................................................48

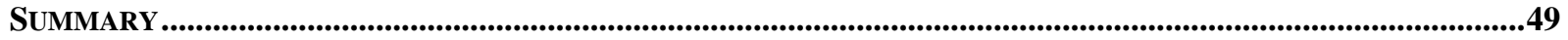

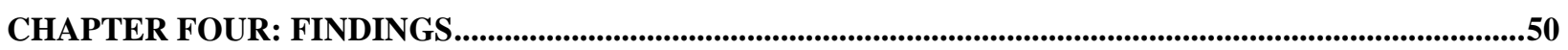

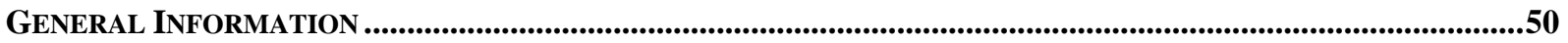

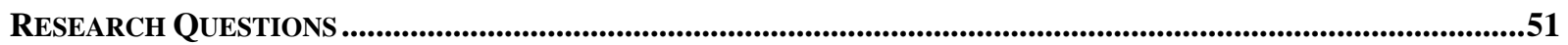

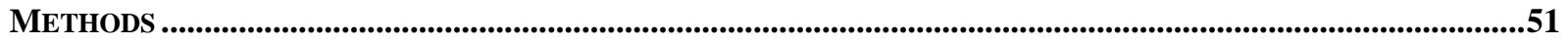

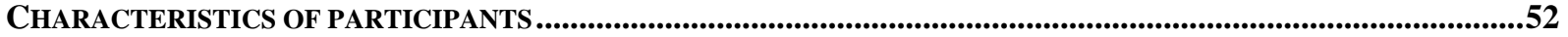

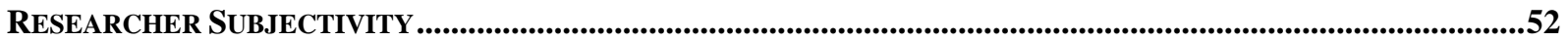

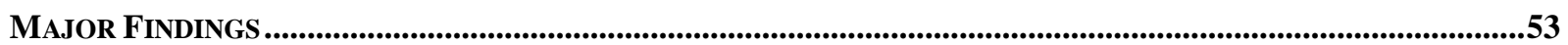

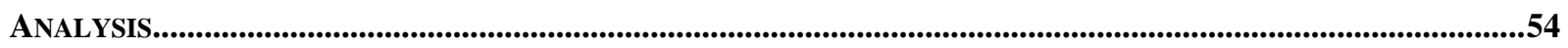

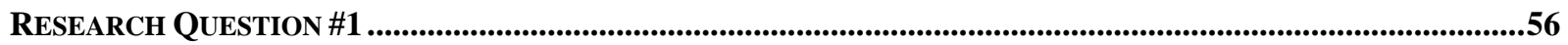

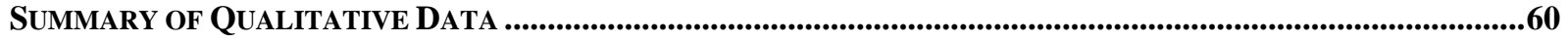

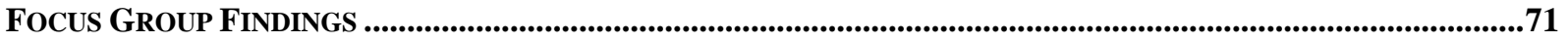

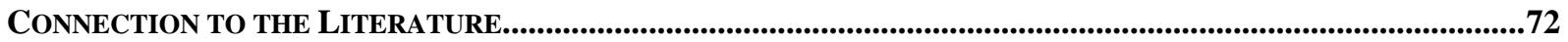

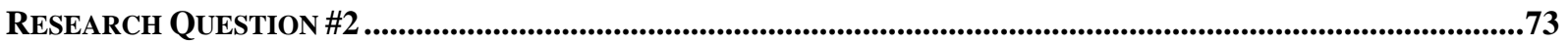

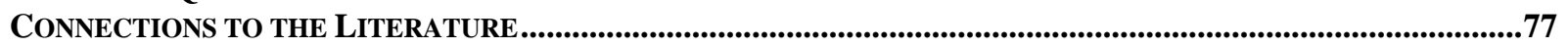

CHAPTER FIVE: SUMMARY, DISCUSSION, AND RECOMMENDATIONS ..............................................79

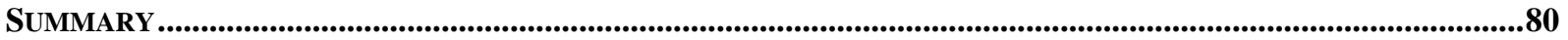

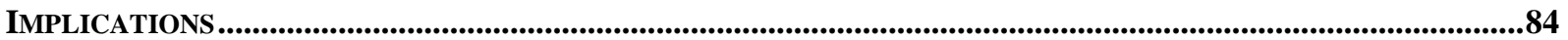

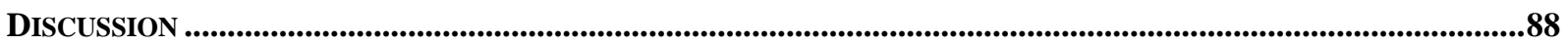

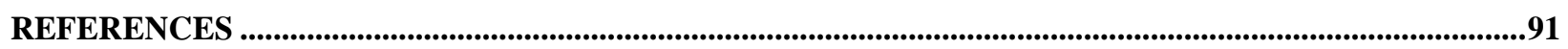

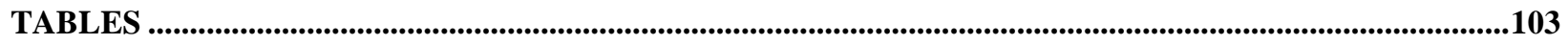

TABLE 1 DEMOGRAPHICS OF POPULATION ..........................................................................................103

TABLE 2: RANKED INFLUENTIAL FACTORS ..............................................................................................105

TABLE 3 INFLUENTIAL FACTORS AS RANKED BY TEACHERS FROM PDSS ...............................................105 


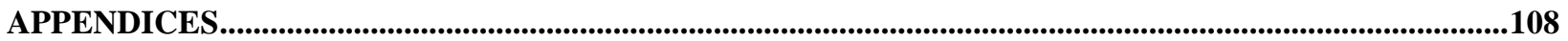

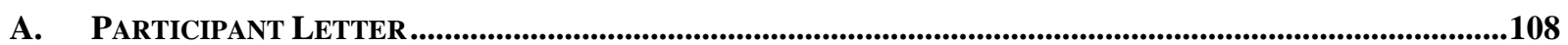

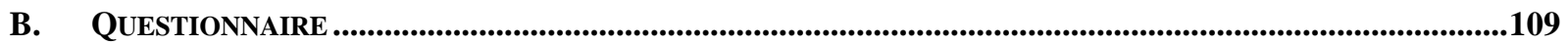

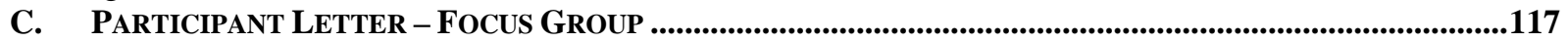

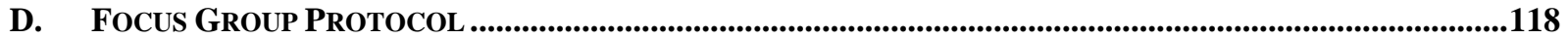

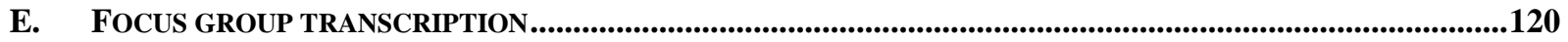

F. NARRATIVE ANSWERS TO OPEN-ENDED QUESTION \#21-33 (ENTIRE POPULATION)..............................126 


\section{CHAPTER ONE: INTRODUCTION}

With increasing pressure from national teacher accreditation associations, the U.S. Department of Education, and state and local governments, the onus is on university teacher preparation programs to recruit, retain, and graduate highly capable teacher candidates. Upon graduation, these newly minted teachers must be able to meet the demands of the $21^{\text {st }}$ century classrooms and students. To address these demands, teacher education programs must ensure that their candidates have access to a variety of learning experiences. Arguably, the most important of these experiences are the clinical experiences where teacher candidates actually practice their craft before licensure as professional educators (Act, 2012; Zionts, Shellady, \& Zionts, 2006). While there may be field/clinical experiences at various points throughout the teacher preparation program, generally the most meaningful and longest in duration is the last requirement for a prospective teacher clinical practice. At a minimum, the teacher candidate experience requires students to spend their last semester gaining real-world experience teaching in a school with established teachers serving as mentors.

In 2011, the National Council on Teacher Quality (NCTQ) reported several findings. NCTQ cites:

* there were not enough qualified teachers willing to mentor teacher candidates;

many teacher preparation programs did not spend enough time placing candidates with effective mentors;

Moreover, institutions depend too much on school districts to help place teacher candidates (National Council on Teacher, 2011; Sawchuk, 2011a; 2011b U.S. News Launch Teacher Education Review).

This report implies that teacher preparation programs are failing to fulfill their responsibilities when it comes to clinical placements, new challenges appear to be emerging making it 
increasingly difficult to negotiate placements for clinical practice (Newton, Jolly, Ockerby, \& Cross, 2012; O'Keefe, Burgess, McAllister, \& Stupans, 2012). Although not totally understood, the range there has been a shift for placement compared the amount of placements needed. Therefore an examination of the role of cooperating teachers in the final mentoring process is imperative (Rajuan, Beijaard, \& Verloop, 2007, 2010; Rozelle \& Wilson, 2012).

Effective teaching has been at the center of highly charged public debate about education reform resulting in heavy scrutiny for both the schools that serve our children and the university programs that prepare our teachers (Hall, Draper, Smith, \& Bullough, 2008; Ronfeldt, 2012; Ronfeldt \& Reininger, 2012). These reform efforts often call for a new approach for teacher preparation programs, and clinical practice is at the forefront of these new expectations. In response to the demand for improved teacher efficacy, teacher preparation programs are strengthening clinical experiences by incorporating more real-world experiences for teacher candidates - observations, internships, and student teaching placements that are longer, more intense, and more frequent (Hall et al., 2008; Huisman, 2007; Ronfeldt, 2012; Ronfeldt \& Reininger, 2012).

Though few would dispute the value of clinical practice programs for teachers, the actual management of providing apprenticeships for approximately 200,000 teacher candidates in the United States each year in real classrooms is a massive and complex undertaking (National Council on Teacher, 2011). About 1,400 higher education institutions work with thousands of school districts across the United States to place, mentor, and supervise teacher candidates (Sawchuk, 2011a). Unfortunately, the dilemma lies in the dichotomy between the need for more clinical placements and the challenges faced by clinical faculty negotiating those placements. With the expectation of rigor, relevance, and relationship along with the pressure of high-stakes testing, classroom teachers and school administrators are cautious about providing clinical and 
field-based experiences for teacher candidates (Ediger, 2009; T. Kim \& Danforth, 2012; Sherman, 2001; Sim, 2011). Often times, this uneasiness creates barriers which manifests difficulty in negotiating opportunities for teacher candidates to practice teaching in a K-12 setting.

Even though school professionals reap benefits from mentoring teacher candidates, there are pressures from administrators and the state department of education that affect their decision to mentor clinical students. Reportedly, classroom teachers accept and refuse mentorship opportunities for a variety of reasons (Cochran-Smith et al., 2012; Rieg, Paquette, \& Chen, 2007; Smith, 2008). Issues such as: teacher candidates interrupt the flow of the classroom and the learning environment; the expectations placed on classroom teachers from universities add to the already inundated stack of paperwork and places a higher level of commitment on an already stretched professional; and the teacher candidates lack professional and content knowledge (M. Kim \& Schallert, 2011; Rozelle \& Wilson, 2012). Most colleges of education require the cooperating-teacher to collect observation data, complete mid-term and final evaluations, contribute to the acquisition of professional development opportunities, and lastly, model positive teaching practices for very little or no additional compensation (Cuenca, 2011; C. Evans, Williams, King, \& Metcalf, 2010; G. T. Henry, Kershaw, Zulli, \& Smith, 2012; Kirkpatrick, Lincoln, \& Morrow, 2006)

Although there are several reasons that teachers choose not to mentor teacher candidates, there are also reasons that cooperating teachers do choose to mentor teacher candidates. In 1982 Stout, surveyed secondary teachers to determine why teachers welcomed teacher candidates to practice in their classroom. This study was foundational to the several studies that took place in the 1990s and 2000s (Maltas \& McCarty-Clair, 2006; McCann, 2012; Rajuan et al., 2007). Throughout several studies, the cooperating teachers listed their reasons for mentorship. Those 
reasons span over several categories including professional obligation, having a new face in the classroom, and some assume the role of cooperating-teacher as professional commitment. Conversely, they embrace the mentorship role because of the professional growth they experience (Maltas \& McCarty-Clair, 2006; McCann, 2012; Rajuan et al., 2007, 2010). Others reported that they derived professional development, thought the classroom experience was an essential event in teacher preparation, and participated in the clinical process to help the aspiring teacher (Larson, 2005; McCann, 2012; Melody \& Jared, 2011; "Turning Into Teachers: Influences of Authentic Context Learning Experiences on Occupational Identity Development of Preservice Music Teachers," 2011). This situation often leaves over-extended school personnel reluctant to provide the clinical experiences that are required to prepare upcoming generations of teachers (Hogan, 2011). Thus, it is understandable that classroom teachers may hesitate when considering adding more stress and responsibilities to an already stressful situation. New and competent teachers, the very thing school districts need, often cause tension before they can offer relief.

Teacher candidates need to have multiple experiences in the classroom in order to evaluate their effectiveness and put into practice the theories they have learned during their teacher education program coursework. Researchers emphasize that teacher candidates need to be able to practice the methods and strategies they have learned during their teacher education training (Cochran-Smith \& Power, 2010; Darling-Hammond, 2011b; Floden, 2012; G. T. Henry et al., 2012). I constructed this study to determine factors that influence teachers when they are deciding to mentor teacher candidates. The research supports putting clinical and field-based experiences at the highest priority for teacher candidates and preparation program design, but the research also reports a dearth of meaningful clinical experiences (Cochran-Smith et al., 2012; Cochran-Smith \& Power, 2010; Darling-Hammond, 1996a, 1996b, 2012a, 2012b, 2012c; 
"Transforming Teacher Education Through Clinical Practice: A National Strategy to Prepare Effective Teachers," 2011). Clinical and field experiences not only offer the opportunity to see what the reality of schools is, but it offers teacher candidates opportunities to sharpen skills, gain practical experiences, and grow professionally. However, this can only occur if teachers are willing to mentor teacher candidates.

Purpose of the Study

The purpose of the study was to identify practicing PK-12 teacher perceptions about clinical and field placements for teacher candidates that affect their decision to accept or reject opportunities to mentor teacher candidates in student teaching experiences. The teachers participating in the study were affiliated with, Moutaskis University, a teacher preparation program in the eastern mid-Atlantic region of the United States. Examined widely among policy makers, teacher educators, and educational administrators are the characteristics of teacher candidates, however; few studies have detailed the reasons that cooperating teachers may be eager or reluctant to mentor teacher candidates. Anecdotal evidence and logic suggest that the teachers who work with teacher candidates can add a new voice to the literature (Hogan, 2011). Research Question(s)

This study examined the factors associated with the decisions by practicing teachers to accept or reject opportunities for participating in mentoring teacher candidates in student teaching experiences.

1. What are the factors that affect the decision by practicing PK-12 teachers to accept placement of teacher candidates in clinical experiences?

2. Are the factors that affect the decision by practicing PK-12 teachers to accept placement of teacher candidates in clinical experiences significantly different based on the teacher's working at a school identified as a professional development school or non- PDS? 
3. Are the factors that affect the decision by practicing PK-12 teachers to accept placement of teacher candidates in clinical experiences significantly different based on selected teacher demographic?

Significance of the Study

This study is important to teacher educators who design and implement guidelines for teacher education programming, teacher candidate evaluation, field experiences, clinical practice, and professional development. Having a better understanding of the barriers to placement will provide teacher preparation programs, K-12 administrators, and education policy makers with a set of tools to address the barriers and to improve on the perceived incentives. These data will allow educational stakeholders understanding why placing candidates have become increasingly difficult in this particular area. With these data, education faculty, school administrators and other educational partners can begin to determine programmatic changes necessary to meet the needs of both teacher candidates and teachers as well as develop better opportunities for placement of teacher candidates. 


\section{Definition of Terms}

In order to frame the parameters of this study, the definition of certain terms is important. The following definitions are specific to the state used in this study. Although, defining these terms allow application of the study's findings beyond local boundaries by accounting for those variations.

Cooperating teacher is a teacher designated to mentor, guide, and monitor a teacher candidate during practicum experiences and/or clinical practice ("Transforming Teacher Education Through Clinical Practice: A National Strategy to Prepare Effective Teachers," 2011).

Clinical practice is student teaching or internships that provide candidates with an intensive and extensive culminating activity. Characterized by full immersion into the learning community and provided opportunities to develop and demonstrate competence in the professional roles for which they are preparing. It is distinguished from field experiences, defined as a variety of early and ongoing field-based opportunities in which candidates may observe, assist, tutor, instruct, and/or conduct research ("Transforming Teacher Education Through Clinical Practice: A National Strategy to Prepare Effective Teachers," 2011).

Field experiences are a variety of early and ongoing field-based opportunities in which candidates may observe, assist, tutor, instruct, and/or conduct research. Field experiences may occur in off-campus settings such as schools, community centers, or homeless shelters ("Transforming Teacher Education Through Clinical Practice: A National Strategy to Prepare Effective Teachers," 2011). In the state under study, field experiences are school settings only.

Professional development schools (PDSs) are innovative institutions formed through partnerships between professional education programs and $\mathrm{P}-12$ schools. PDS partnerships have a four-fold mission:

- the preparation of new teachers, 
- faculty development,

- inquiry directed at the improvement of practice, and enhanced student achievement ("Transforming Teacher Education Through Clinical Practice: A National Strategy to Prepare Effective Teachers," 2011)Teacher candidate - Individuals that are admitted to, or enrolled in, programs for the initial or advanced preparation of teachers, teachers continuing their professional development, or other school professionals. Candidates are distinguished from students in P-12 schools ("Transforming Teacher Education Through Clinical Practice: A National Strategy to Prepare Effective Teachers," 2011).

University supervisor - The university faculty member or adjunct designated to provide overall supervision for teacher candidates (Weimer, 2011).

\section{Organization of the Document}

Divided into five chapters, this document contains an introduction, a literature review, a methods section, a findings section and, discussion of the research, a reference list, and appendices. Chapter Two is a review of the relevant literature related to the factors that affect PK-12 teachers' decision to accept or reject the opportunity to mentor teacher candidates during their student teaching. Chapter Three is the research methods for this study, including a discussion of the data collection instrument and analysis. Chapter 4 will discuss findings; chapter 5 will describe the summary, conclusions, and recommendations for practice and further research. 


\section{CHAPTER TWO: REVIEW OF LITERATURE}

Approximately 200,000 students graduate from teacher preparation programs each year, joining the 3.6 million public school teachers in 90,000 elementary and secondary schools (Sawchuk, 2011a, 2011b). Teachers enter the profession through traditional or alternative programs, and the program characteristics within these designations vary significantly. To improve teacher quality, policymakers need to address the preparation of teacher candidates. Yet the research base in this area is quite weak, offering no particular formula for an effective teacher-training program. There is much support for additional clinical experiences strategically placed throughout the preparation program (S. I. Kent, 2001; Moehle, 2011). In taking steps to evaluate and improve teacher preparation, state education leaders need to consider a number of factors in building effective teacher training programs. When describing current efforts in teacher preparation, it is imperative that the discussion must include the challenges facing preparation programs and the teaching profession. Current research, particularly the Holmes initiative surrounding professional development schools, suggests several actions education policymakers can take to foster improvement in teacher training programs:

- raise admissions requirements to attract high-quality candidates

- require programs to be aligned with expectations for student learning

- require meaningful field experiences for prospective teachers

- create an evaluation and accountability system to inform continuous program improvement (Holmes, Polhemus, \& Jennings, 2005; Leonard, Lovelace-Taylor, Sanford-Deshields, \& Spearman, 2004)

Because teacher training is a large industry characterized by great variation, the purpose of this study will focus on a traditional teacher preparation programs and clinical experiences. 


\section{Teacher Quality}

Teacher quality is the single most influential school-based factor in improving student learning, and is the primary factor that drives teacher preparation programs (Cochran-Smith et al., 2012; Floden, 2012; G. T. Henry et al., 2012). The Hunt Institute (2012) reports that, the most effective teachers produce, on average, one-and-a-half grade levels of growth each year, a level sufficient to close the achievement gap for low-income students. Given this influence, it is essential for state education leaders to ensure the recruitment, training, and retention of teachers in a manner that gives all students access to the most effective teachers possible. Although this study will examine the factors associated with the decision by practicing teachers to accept or reject opportunities for participating in the mentoring of teacher candidates, the need for highquality training for teachers is at the crux of the study. Effective training empowers teachers to develop and deliver instruction effectively, and real-life clinical experiences give students the opportunity to sharpen the craft of teaching (Darling-Hammond, 2006c; Lu, 2007).

In January 2014, The National Council on Teacher Quality released its seventh annual State Teacher Policy Yearbook, which includes a 360-degree analysis of every state law, rule, and regulation that shapes the effectiveness of the teaching profession each state. The state that this research study was conducted in received an overall grade of $\mathrm{C}-$, an improvement over its grade of D+ in 2011, the last year the state's full portfolio of teacher policies was graded (Greenberg, McKee, Walsh, \& National Council on Teacher, 2013). This year, the average grade across all 50 states and the District of Columbia is C-. Even though the grades seem abysmal, many states have made gains and the 2013 State Teacher Policy Yearbook proves that it is both possible and practical for states to drive teacher effectiveness policy. Many states are raising the bar for teacher preparation, licensing, and evaluation and are connecting personnel decisions on quality not on tenure (Greenberg et al., 2013). 
NCTQ cites the areas of concern continue to center around teacher effectiveness. Unfortunately in many states, teacher evaluation is not tied to student achievement/academic growth (Greenberg et al., 2013). While annual evaluations are required of all teachers, and teacher evaluations are required to include some objective evidence of student learning, the state is one of only 16 that does not requires student achievement/growth to be an important criterion in evaluating teacher effectiveness. Other issues that NCTQ cited were the rare dismissal of ineffective teachers, and tied to tenure years of experience not performance. Twenty-nine states, including the state where this study took place, articulate that classroom ineffectiveness is grounds for a teacher's dismissal, however, teacher tenure decisions are made virtually automatically after three years, with no consideration of classroom effectiveness (Greenberg et al., 2013). Lastly, the state studied still operates under the "last in, first out" policies. In light of the findings, there have been changes made at the state level to remedy some of these findings.

NCTQ (2013) reports that progress in setting higher standards for teacher preparation, and there is room for improvement. Keeping in mind that teacher preparation is an iterative process much like the field of Medicine, best practices and standards are constantly evolving. Improvements made to Elementary teacher preparation:

Elementary school licensure requires separate passing scores for each subject, which helps to ensure teachers, know core content they will teach (Greenberg et al., 2013). * Elementary licensure requires a rigorous test of scientifically based reading knowledge for elementary and early childhood teachers.

Conversely, NCTQ found significant loopholes in our secondary teacher licensing requirements, and it was recommended that all secondary teachers pass a content test in every subject they are licensed or have an endorsement to teach (Greenberg et al., 2013). On a high note, NCTQ commended special education licensing criteria. No longer is there a K-12 special education 
license, a license that wrongly presumes special education teachers do not need to master grade and subject specific content knowledge. Finally, NCTQ recommends that institutions of higher education raise admission requirements for teacher preparation programs. NCTQ and CAEP agree that it is necessary to strengthen teacher preparation by raising admission requirements to ensure that teacher preparation programs admit candidates with strong academic records, and requiring a minimum GPA of 3.0 is one way to begin this process (Denzin \& Lincoln, 2013; Greenberg et al., 2013; H. A. Johnson, 2013).

\section{Clinical Practice}

To frame how the perception of clinical practice has changed over the years, this section begins with a history of clinical practice. The concept of practical experience in teacher preparation goes back at least to the 19th century, when the normal school movement produced four core categories of study for teachers, one of which was practice teaching. For the next 150 years, expectations of what teachers should know and be able to do changed very little, although preparation typically included a component labeled observation and practice, in-school practicum, field experience, or, more commonly, student teaching (Hoxie, 2010; Petrilli, Finn, \& Thomas, 2011; Riggsbee, Malone, \& Straus, 2012). Outlining the model for academic programs is as follows; teacher candidates completed course work on psychological principles, subject matter, and teaching methods before beginning student teaching-for about 8 weeks at the end of the program-with few connections to course content. Unfortunately, more often than not, space and acceptance trumps quality. Placements were idiosyncratic, with experiences ranging from primarily clerical work (copying papers, grading papers, assisting the teacher, but not teaching) to solo teaching without assistance (Riggsbee et al., 2012). Because, university- and schoolbased faculty did little joint planning or teaching, candidates learned theory in isolation from practice and had just a quick encounter with classroom practice divorced from theory. New 
teachers trained in this way, when entering their own classrooms, thus reverted largely to what they knew best- the way they themselves had been taught (Riggsbee et al., 2012).

Twenty-first century teacher preparation is changing. When interviewed by U.S. World News, Thomas James, the provost and dean of the college at Columbia University's Teachers College, stated, "We see student teaching as the centerpiece of learning to be a teacher. Everything else is built around the clinical experience. Field experiences are built into the curriculum from the beginning, with observational and collaborative work. When it comes time to do their student teaching, they've already spent a lot of time in the classroom (Sawchuk, 2011a)." This statement is different from our past views of clinical practice of the past. Clinical practice has moved to the forefront of the educational experience for prospective educators. The 21 st century has become a watershed in recognizing the importance of high-quality clinical programs in teacher preparation. Teachers for a New Era (TNE), a large-scale, multiyear grant program of the Carnegie Corporation of New York launched in 2001, supported innovation in teacher education programs at selected colleges and universities (Voltz \& Fore, 2006). Based on the premise that excellent teaching is a clinical skill and that exemplary teacher education provides for clinical education in a clinical setting. One of TNE premises was that "education should be understood as an academically taught 'clinical practice profession,' requiring close cooperation between colleges of education and actual practicing schools; master teachers as clinical faculty in the college of education; and residencies for beginning teachers during a twoyear period of induction." This was a different from traditional notions of student teaching. This work laid the foundation for other research such as the Blue Ribbon Panel on Clinical Preparation and Partnerships for Improved Student Learning of 2011, and Transforming Teacher Education through Clinical Practice: A National Strategy to Prepare Effective Teachers in 2011. 
In recent years, foundations and the federal government have sponsored initiatives promoting innovation in the clinical experience component of teacher preparation programs (Moehle, 2011). Clinical practice may include laboratory experiences and coursework that provide, for example, demonstration videos, analysis of case studies, and peer teaching, in addition to more traditional classroom observation and student teaching ("Transforming Teacher Education Through Clinical Practice: A National Strategy to Prepare Effective Teachers," 2011). Researchers agree that high-quality practical experience is important in learning to teach. As defined by the NEA, high quality practical experiences are strategically planned, pointed, experiences that are guided by masterful professionals in the PK-12 setting ("Transforming Teacher Education Through Clinical Practice: A National Strategy to Prepare Effective Teachers," 2011). When done well, these experiences ensure teacher candidates are given the opportunity to apply the theory and methods that they have acquired in the classroom (DarlingHammond, 2006a; S. I. Kent, 2001; "Transforming Teacher Education Through Clinical Practice: A National Strategy to Prepare Effective Teachers," 2011). Like other parts of teacher preparation, the scope and duration of clinical and field experiences vary, but the literature supports more early experiences, and placements that are more meaningful. Some programs place candidates in the classroom at the beginning of the program, while others require candidates to complete a capstone or a final project in the field.

Although important to the development of new teachers, clinical practice is always a source of concern. Not only is it difficult finding enough placements for teacher candidates, it is also plausible that some of the placements negotiated are toxic environments to prospective teachers. Over the past few years, NCTQ has studied both teacher preparation programs and clinical experiences. Even though this research project is not about the effectiveness of teacher candidate placements directly, it is important to understand that clinical practice is plagued with 
problems that influence candidate preparation. In 2012, NCTQ released a study reporting that many of the nearly 200,000 new teaching candidates had ineffective mentors during their candidacy. NCTQ defines ineffective mentors in several ways, but the two most commonly used descriptors were mentors that were inexperienced and /or unaware of their roles and responsibilities. Typically, teacher candidacy the last requirement for a prospective teacher and most schools require students to spend their last semester gaining real-world experience teaching in a school with an established teacher who serves as a teacher candidate mentor (Sawchuk, 2011a). Among the report's findings: There were not enough qualified teachers willing to mentor teacher candidates; many teachers' colleges did not spend enough time placing teacher candidates with effective mentors; and institutions depend too much on school districts to help place teacher candidates. Unfortunately, the barriers that face teacher candidate placements could negatively influence prospective teachers or teach bad habits to vulnerable candidates. Another study by NCTQ completed in July 2011 rated 134 student-teaching programs nationwide — about one-tenth of existing programs — based on the organization's own criteria for high-quality student teaching programs (Sawchuk, 2011a, 2011b). The state where this study took place was not a part of this study, but the information it provides is foundational to this study. The resulting report found that only seven percent of the programs were model programs, and seventy-five percent were weak. The weak criteria were as follows:

$>$ duration of teacher placement;

role of the teacher preparation program in teacher placement;

teaching experience of those serving as mentors;

mentor's demonstrated capacity to have a positive impact on student learning; and the capacity of the mentor to provide meaningful feedback (Sawchuk, 2011b). 
Critics of the study question the NCTQ's rubrics and methodology. Though definitive guidance regarding the format and timing of clinical experiences is not available, it is clear that this component of teacher preparation must include opportunities to apply knowledge, test new skills, and receive feedback.

The National Research Consortium's Preparing Teachers: Building Evidence for Sound Policy (2010) reported that most teacher educators and students view clinical experiences as a valuable part of teacher training. According to the report, early research studies do not directly support the relationships between field experiences and teacher effectiveness. However, the report went on to say that, recent studies, such as Boyd et al. (2008), indicate that when teachers participate in field experiences that are related to future teaching positions and have professional oversight, the experience is of great benefit. The second report reveals considerable promise and comes from the Blue Ribbon Panel (2011). Commissioned by National Council for Accreditation of Teacher Education (NCATE) to study how to prepare effective teachers, a diverse group of educational stakeholders including teachers, union representatives, and leaders in higher education, state officials, and outspoken critics of the current education system comprised this panel. The panel released its recommendations in a publication titled, Transforming Teacher Education through Clinical Practice: A National Strategy to Prepare Effective Teachers.

The Blue Ribbon Panel report discussed the gap between what schools need and how teachers are trained, after examining the status of components in current teacher preparation programs("Transforming Teacher Education Through Clinical Practice: A National Strategy to Prepare Effective Teachers," 2011). They found that clinical practice does not have a coherent definition nationwide. Many states require student teaching; however, most do not have a guide for the experience, nor are there any accountability measures for these clinical experiences. 
Most importantly to this study, the panel reported that mentors are often used, but few states require training and support for a teacher to become a mentor. Based on the best available research, the panel felt that clinical preparation and mentor programs would be more effective if proven methods were the foundation of those experiences.

Moehle (2001) states, that the purpose of clinical practice is to provide a structured experience for learning and refining the skills necessary to become an effective teacher of students with diverse abilities and backgrounds. When teacher candidates are expected to exhibit the abilities to organize, plan, communicate, and evaluate learning experiences, they gain the real world experiences needed to be successful in today's classroom (Pellett \& Pellett, 2009; "Transforming Teacher Education Through Clinical Practice: A National Strategy to Prepare Effective Teachers," 2011). Additionally teacher candidates, who participate in all activities expected of their cooperating teachers, gradually assume responsibility, and leave the experience better prepared. Although teaching in the clinical setting is difficult and time consuming, the most significant reason that the literature supports clinical experiences is that it places students in real life learning situations (Moehle, 2011). Although teaching in the clinical setting is difficult and time consuming, the most significant reason that the literature supports clinical experiences is that it places students in real life learning situations (Moehle, 2011). This model helps students generalize experiences and it changes information processing the acquisition of knowledge. This transition links theory to practice, and makes it easier to recall when a similar situation is encountered (Darling-Hammond, 2011a). Secondly, it prepares students for the sort of work they will have to face as practitioners. Finally, in a perfect world, it shows students how a master teacher operates. Ideally, teacher candidates have the opportunity to shadow, co-teach, and have the support of a master teacher during their field and clinical experiences. Because field and clinical experiences occur in protected environments, teachers can show candidates 
how and when to use strategies, how to address learning problems, how to positively support behavioral issues, how to interact with parents, and many more real-life issues that face teachers daily (Darling-Hammond, Dozer, Johnston, \& Rogers, 2006; Lu, 2007; Moehle, 2011). Teacher candidates observe day-to-day school activities, and get to see and experience the rapidity of teaching. In addition, teacher candidates get to observe professional behavior and attitudes and at the same time analyze and discuss professional dispositions. Clinical experiences position cooperating teachers in a role-modeling situation. Role modeling takes place covertly and overtly, and in the clinical setting cooperating teachers have the responsibility of acting as a positive role model (Darling-Hammond \& Berry, 2006; Moehle, 2011).

For teacher preparation programs, new standards from the Council for the Accreditation of Educator Preparation (CAEP new consolidation of NCATE and TEAC) will raise the bar for accreditation, focusing on outcome data and responsiveness to $\mathrm{P}-12$ needs. Recognized as an academically taught clinical practice profession, such as clinical psychology and medicine, teacher candidates exhibit a complex set of knowledge, skill, and judgments to pass clinical practice. No longer, does the term student teaching simply mean a short practice period at the end of academic course work-is fast becoming obsolete. Substantive partnerships with local schools will help universities meet these requirements by creating opportunities for ongoing input from P-12 colleagues on refining teacher preparation ("Mentoring pre-service teachers: A case study," 2010; Pellett \& Pellett, 2009; Preparing Teachers: Building Evidence for Sound Policy, 2010; Zionts et al., 2006). Most traditional teacher preparation programs believe in the importance of clinical experiences, the profession pushes for more experiences that begin earlier in teacher candidates' academic program. Clinical faculty have the responsibility to make sure that the fieldwork is meaningful, by pairing teacher candidates with master teachers. Focusing on the quality of the placements, clinical faculty are charged with evaluating placements 
including classrooms and school environments (Walkington, 2007). During the typical semesterlong experience, teacher candidates must synthesize everything they have learned about planning instruction: collecting or developing instructional materials, teaching lessons, guiding small group activities, and establishing and maintaining order. Passing or failing student teaching determines whether an individual recommendation for certification as a licensed teacher.

Because few dispute the tremendous value of student teaching, even alternate pathways to the profession try to provide their teacher candidates with some kind of fieldwork, however abbreviated (Boyd, Goldhaber, Lankford, \& Wyckoff, 2007; Carter, Amrein-Beardsley, \& Hansen, 2011; C. Evans et al., 2010; "THE COOPERATING TEACHER AND HUMAN RELATIONS," 1971; Veltri, 2012). Research that surveyed new teachers suggested that they believed that student teaching is the most important part of their teaching training (Bird, 2012; Chambers, Hobson, \& Tracey, 2010; Haskins \& Loeb, 2007; "THE COOPERATING TEACHER AND HUMAN RELATIONS," 1971). While there is consensus that practical experience is essential to teacher preparation, there is disagreement over the best way to acquire experience (J. J. Henry, Tryjankowski, DeCamillo, \& Bailey, 2010; "Turning Into Teachers: Influences of Authentic Context Learning Experiences on Occupational Identity Development of Preservice Music Teachers," 2011). Educational policymakers continue to search for methods to produce competent and prepared teachers. This search has yielded both a call for more meaningful clinical experiences and P-12 partnerships (Crowe \& Center for American, 2010; Moehle, 2011). This also holds for the questions about five-year programs and professional development schools. High-quality field experiences also appear to share several characteristics that lead to teacher effectiveness, but two emerged in the literature (Cochran-Smith \& Power, 2010; Darling-Hammond, 2006a; Stronge \& Hyndman, 2003). Among the most common characteristics identified are (1) strong supervision by well-trained teachers and university 
faculty, and (2) prospective teachers' solid grasp of subject matter and basic understanding of pedagogy prior to student teaching (Cochran-Smith \& Power, 2010). While clinical experience differ among programs, clinical practice seems to be a non-negotiable hurdle in teacher preparation. These questions are particularly pressing during a time when counties and districts must recruit qualified teachers, and when colleges and universities are accountable for sound curriculum and evaluation practices.

\section{Professional Development Schools}

Professional development schools (PDS), have a rich history of enrichment when teacher preparation and teacher quality is concerned. Goodlad and Holmes advocated for the creation of school-university partnerships. They believed that PDS would be a strong vehicle for educational change and a new model for teacher education and professional development for all educators (Goodlad, 1990; Holmes, 1986; Holmes, 1990; Levine, 1992). Darling-Hammond (1998) described Professional Development Schools (PDS) as spaces where prospective teacher and mentor teacher learning becomes 1) experimental, 2) grounded in teacher questions, 3) collaborative, 4) connected to and derived from teachers' work with their students, and 5) sustained, intensive, and connected to other aspects of school change. Today, many universities and school districts have joined to participate in K-12 education reform through the establishment of PDS partnerships (Castle, Fox, \& Souder, 2006). The mission of PDS states that PDS are committed to developing exemplary practices to maximize student outcomes, provide optimum sites for teacher preparation, offer research-based teacher professional development, and implement reflective inquiry to enhance learning for all (Cheng \& So, 2012; Latham \& Vogt, 2007; Pellett \& Pellett, 2009). In addition to these purposes, PDS serve as vehicles for simultaneous renewal of schooling and teacher preparation (Doolittle, Sudeck, \& Rattigan, 2008; Pratschler, 2009). In order to accomplish this educational agenda, PDS need 
ongoing opportunities to examine partnership goals and purpose (Leonard et al., 2004;

Pratschler, 2009).

In support of clinical and field experiences, NCATE encourages the addition of more experiences, especially those experiences that take place in professional development schools. Research from the National Association of Professional Development Schools (NAPDS), NCATE, and the American Association of Colleges for Teacher Education (AACTE), states that PDS improve both the quality of teaching and student learning, and by immersing candidates into classrooms with masterful teachers, and supporting the professional needs of both the candidate and the cooperating teachers. PDS are often compared to teaching hospitals, which are also hybrid institutions created in the early twentieth century (Castle et al., 2006; Cheng \& So, 2012; Darling-Hammond, 2005b; Darling-Hammond \& Berry, 2006; Darling-Hammond et al., 2006; Pellett \& Pellett, 2009; "Transforming Teacher Education through Clinical Practice: A National Strategy to Prepare Effective Teachers," 2011; Zionts et al., 2006). NCATE compares teaching and medicine because both are practicing professions and both require a sound academic program and intense clinical preparation ("Another Debate--the Quality of Teacher Preparation Programs," 2007; Darling-Hammond, 1999a, 1999b; "Engaging our fears: student learning at the center of our practice," 2007; "Transforming Teacher Education Through Clinical Practice: A National Strategy to Prepare Effective Teachers," 2011). Designed to provide clinical preparation for medical students and interns, the teaching hospital is much like PDS. PDSs serve the same function for teacher candidates and in-service faculty. Both settings provide support for professional learning in a real-world setting in which practice takes place (Brucklacher, 1998; Vaughn, 2012).

Schools need continual learning opportunities that address specific goals or challenges for their teachers. In an economic climate of cuts to state and local education budgets - with 
professional development and support for new teacher induction often among the first cuts when budgets are reduced - schools are in need of low-cost professional development (J. J. Henry et al., 2010; Hobbs \& Bullough Jr, 1998; Koehnecke, 2001; Leonard et al., 2004). PDS programming can offer low cost professional development. Local schools in strong partnerships can tap into university faculty members' expertise for professional development sessions perhaps in areas like data-driven decision-making, instructional technology, or differentiated instruction - at low or no cost. Conversely, practitioners can offer expertise in current practices to methods faculty. The collaboration is continuous, and all stakeholders have value (Castle et al., 2006; Corte, Brok, Kamp, \& Bergen, 2013; Leonard et al., 2004; Walkington, 2007). Collaborating with teacher preparation programs gives teachers and school leaders a role in building their future workforce. By becoming more involved in teacher preparation, local schools can share their needs with university partners and help design the programs that will prepare teachers who can address those needs. Schools can increase their chances of hiring novice teachers prepared for the realities of teaching in their classrooms (Bird, 2012; Rozelle \& Wilson, 2012; Scherer, 2012).

Universities need effective teachers from partner schools who are willing to accept teacher candidates in clinical placements and help with teacher preparation through mentorship. Strong cooperating teachers can enhance the effectiveness of teacher candidates, who will ultimately benefit schools, as they become more effective novice teachers (Hogan, 2011 612; McCann, 2012 367; Nilssen, 2010 539; Rozelle \& Wilson, 2012 372). Working with local schools also gives university faculty members a better understanding of the environments in which their teacher candidates will go through clinical practice and eventually teach. This dynamic prepares new teachers better for real-world classroom practice (L. Evans, 2010; Weimer, 2011; Woods \& Weasmer, 2003). 
Partnerships between schools and university require hard work and investments by school and university personnel. Successful partnerships demonstrate mutual benefits, by offering educational and professional renewal, professional development, and incubators for ideas, strategies and learning. Collaborating can help schools and universities meet the requirements of new learning standards and program accreditation models (Cheng \& So, 2012; "Transforming Teacher Education Through Clinical Practice: A National Strategy to Prepare Effective Teachers," 2011).

The University under study is young in the world of professional development schools. The PDS program began in 2003, and has had several iterations since its inception. In the early stages of PDS, there were few requirements for schools to become a part of the PDS program. Currently, school selection is determined on desire. If a principal and staff express an interest in becoming a PDS, they complete an application. Based on funding, the applications to-date have a $100 \%$ acceptance rate.

\section{Factors found in the Literature}

There have not been many studies conducted that specifically focused on the factors influencing teacher decisions about providing meaningful placements, however; the literature suggests that the role cooperating teachers play is not only important, but it is the conduit for success in teacher education programs. Upon further investigation, the researcher uncovered several teacher concerns. In 1984, Whaley and Wolfe concluded that - cooperating teachers, as a group, could make serious efforts to improve their profession. The assumption is often made that experienced teachers would naturally be motivated to mentor a teacher candidate, but this is not always the case (Anderson, 2007; T. Kim \& Danforth, 2012; McCann, 2012; "Turning Into Teachers: Influences of Authentic Context Learning Experiences on Occupational Identity Development of Preservice Music Teachers," 2011). Even though cooperating teachers have the 
ability to influence teacher education by providing teacher candidates with meaningful clinical experiences, studies show that cooperating teachers who are willing to accept teacher candidates are not always the best placement teacher candidates (Anderson, 2007; Larson, 2005; McCann, 2012; Rajuan et al., 2010; Sherman, 2001; Sim, 2011). Several changes took place during the two decades between these two studies, professional development schools and partnership agreements between universities began to develop, and conversations about teacher candidate evaluation began to emerge and a new level of accountability became the expectation. Researchers began to focus on the student teaching as a whole. Out of the newly defined partnerships, some research exists focusing on (a) why the cooperating-teacher would help or not help a teacher candidate, (b) the concerns cooperating teachers report about assisting teacher candidates, and (c) the theories cooperating teachers practice in the classroom. Researchers pursuing these three themes have built a significant body of knowledge. This knowledge base has significantly shaped NCATE and TEAC requirements, state level legislation, and federal policy.

Although there were not several studies conducted that focused on the voice of cooperating teachers, one illuminating study came from China. In the findings, teachers cited the following concerns:

more concerned about their own professional growth rather than spending time assisting and guiding teacher candidates,

concerned that teacher education programs did not prepare the teacher candidates adequately, concerned that university faculty did not acknowledge the cooperating teachers' insights while constructing placements for teacher candidates, and 
concerned that mentoring teacher candidates added unnecessary anxiety to teachers' daily routines (Sinclair, Dowson, \& Thistleton-Martin, 2006).

Interestingly enough even though the educational systems may differ, similar studies conducted across the United States echo similar results (Chaliès, Ria, Bertone, Trohel, \& Durand, 2004; Enz \& Cook, 1992; Hall et al., 2008; Le Cornu \& Ewing, 2008).

In 1986, Applegate and Lasley reported six problems associated with teacher candidate placements. Cooperating teachers reported that teacher candidates exhibited (a) poor preparation in earlier coursework and field experiences, (b) poor understanding about school professionalism, (c) little commitment to teaching, (d) little passion for the content, (e) poor lesson planning and general management skills (Applegate \& Lasley, 1986). Teachers also reported a lack of communication or involvement from the university faculty. Lastly, several studies discussed the absence of the cooperating teachers' influence in teacher candidate placement. University faculty typically made decisions about the placements, the duration of student teaching, the requirement of planning and written work, and final grading (Koster, Korthagen, \& Wubbels, 1998; Nguyen, 2009; Rozelle \& Wilson, 2012; Sherman, 2001; Sim, 2011).

Although there are several reasons that cooperating teachers choose not to mentor teacher candidates, there are also reasons that cooperating teachers choose to mentor teacher candidates. In 1982 Stout, surveyed secondary teachers to determine why teachers welcomed teacher candidates to practice in their classroom. This study was foundational to the several studies that took place in the 1990s and 2000s (Maltas \& McCarty-Clair, 2006; McCann, 2012; Rajuan et al., 2007). Throughout several studies, the cooperating teachers listed their reasons for mentorship such as: professional obligation, having a new face in the classroom, and some assume the role 
of cooperating-teacher as professional commitment, and; later, they continue to embrace the role because of the professional growth they experience (Maltas \& McCarty-Clair, 2006; McCann, 2012; Rajuan et al., 2007, 2010). Others reported that they derived no professional development associated with being a cooperating-teacher but thought the classroom experience was an essential event in teacher preparation, and participated in the clinical process to help the aspiring teacher (Larson, 2005; McCann, 2012; Russell \& Russell, 2011).

Many studies seem to focus on the failures of the teacher candidates, but Cathy Siebert's (2006) study seemed to cast a wide net to cover several of the issues concerning the mentoring relationship between cooperating teachers and teacher candidates. These relationship issues are barriers because cooperating teachers admittedly internalized the performance of the teacher candidates. Indirectly in Seibert's study, cooperating teacher perceptions begin to emerge. Siebert's descriptive study discussed cooperating teachers' concerns about struggling teacher candidates. She depicts the context of teacher preparation as a complex activity, and this statement rightly implies that the circumstances of clinical practice are more rigorous and stressful than years before. According to Siebert, the clinical practice, or any experience where a teacher candidate is practicing in a classroom setting, is not only demanding for the teacher candidate but also demanding for the cooperating-teacher. When a teacher candidate fails to meet the expectations of the cooperating-teacher and the university field supervisor, the cooperating teachers expressed feelings of misery and responsibility (Siebert, Clark, Kilbridge, \& Peterson, 2006). A large majority of cooperating teachers seem to internalize the performance of the teacher candidate placed in their care. Quintessentially, the cooperating teachers felt the same responsibility for the teacher candidate as they did for their own students (Siebert, 2006); they felt the need to create success for the teacher candidate. The cooperating teachers also expressed thoughts as to why the teacher candidate did not meet expectations-including the 
teacher candidates' lack of enthusiasm for content, weakness in content area, unprofessional disposition, and unwillingness to know the students (Siebert et al., 2006).

The literature also reveals that the relationship between the theories covered in textbooks and university courses are not always current. Attributed to the reported lack of communication between the university faculty and cooperating teachers, practitioners report a disconnect between current practices and methods taught. Several studies reported a difference between the theories taught in the university setting and the theories used in practice (Copeland, Keefe, Calhoon, Tanner, \& Park, 2011; Larson, 2005; Montecinos et al., 2011; Scheeler, 2008; Siebert et al., 2006; Trautwein \& Ammerman, 2010; Washburn, Matesha Joshi, \& Binks Cantrell, 2011). Cooperating teachers reported that they spent more time teaching the teacher candidates current practices (Copeland et al., 2011; Larson, 2005; Montecinos et al., 2011; Scheeler, 2008; Siebert et al., 2006; Trautwein \& Ammerman, 2010; Washburn et al., 2011). This gulf between theoretical and practical realms could be why classroom teachers and university professors are often at odds with regard to what represents a good teacher (Zionts et al., 2006). Holmes and Goodlad state philosophically, PDS should close this gap between theoretical and practical application (Goodlad, 1990, 1993). Zionts et al offer another point of contention; practitioners are rarely involved in the process of creating teaching standards presuming that the practicing teachers do not desire to participate in such a process.

\section{Summary}

As this review of the literature broadly demonstrates, placing teacher candidates create various challenges and benefits to cooperating teachers. These challenges and benefits can cause tensions and create barriers when clinical faculty try to negotiate meaningful clinical placements. Teacher education programs must be aware of the current issues surrounding the placement, especially with accrediting entities pushing for more experiences that are clinical. There appears 
CLINICAL PLACEMENT FACTORS 28

to be growing concern regarding the placement of teacher candidates in today's classroom, and this study will explore those concerns. 


\section{CHAPTER THREE: RESEARCH METHODS}

The purpose of this mixed methods study was to identify practicing PK-12 teacher perceptions about clinical and field placements for teacher candidates that affect their decision to accept or reject opportunities to mentor teacher candidates in student teaching experiences. This study informs stakeholders in education (teacher education faculty, school administrators, schoolteachers, and licensure officers) about how cooperating teachers decide to mentor teacher candidates. This study listened to the voice of the cooperating teacher. As policy changes are made and teacher quality indicators redefined, it is important to know how PK-12 teachers view clinical experiences. The data derived from this study will assist stakeholders in determining necessary changes in teacher education programs particularly clinical experiences. This study will provide evidence as to why it is becoming increasingly difficult to place teacher candidates, and this evidence can help construct a dialog between universities and school communities directed at improving the outcome of teacher education programming. Armed with this information, teacher education programs can become pro-active.

The teachers participating in the study teach within a six county radius of Moutaskis University a teacher preparation program in the eastern mid-Atlantic region of the United States. Examined widely among policy makers, teacher educators, and educational administrators are the characteristics of teacher candidates, however; few studies have detailed the reasons that cooperating teachers may be eager or reluctant to mentor teacher candidates. Anecdotal evidence and logic suggest that the teachers who work with teacher candidates can add a new voice to the literature (Hogan, 2011).

This study will examine the factors associated with the decision by practicing teachers to accept or reject opportunities for participating in mentoring teacher candidates in student teaching experiences. The research questions introduced earlier are as follows: 
1. What are the factors that affect the decision by practicing PK-12 teachers to accept placement of teacher candidates in clinical experiences?

2. Are the factors that affect the decision by practicing PK-12 teachers to accept placement of teacher candidates in clinical experiences significantly different based on the teacher's working at a school identified as a professional development school?

3. Are the factors that affect the decision by practicing PK-12 teachers to accept placement of teacher candidates in clinical experiences significantly different based on selected teacher demographic?

In 2011, the institution under study, found increasing barriers to negotiating placements for teacher candidates. To keep the institutions identity confidential the researcher used a pseudonym, Moutaskis University. Carnegie classifies Moutaskis University as a medium sized balanced arts \& sciences/professions, high graduate coexistence institution and is located in the eastern mid-Atlantic region of the United States. Typically, Moutaskis University graduates 100-120 teacher candidates per semester. After communicating with school administrators, practicing teachers, and cooperating teachers involved with other teacher education programs, researchers found a growing reluctance to place teacher candidates into field-based and clinical experiences (Hess \& Darling Hammond, 2011; A. M. Kent, 2005; Ledoux \& McHenry, 2008). However, the literature reports that university supervisors and teacher candidates believe that the reluctance comes from the classroom teachers (Cuenca, 2011; Cuenca, Schmeichel, Butler, Dinkelman, \& Nichols, 2011; Nguyen, 2009; Scheeler, 2008; Talvitie, Peltokallio, \& Mannisto, 2000). This left several questions unanswered: Is this placement barrier occurring because experienced teachers feel that teacher candidates are not prepared to practice teaching? Alternatively, are the threatened consequences of poor scores in standardized testing turning experienced teachers away from mentoring teacher candidates? Alternatively, do experienced 
teachers feel that the presence of teacher candidates challenges their sense of control or autonomy in their classrooms?

The purpose of the study is to identify practicing PK-12 teacher perceptions about clinical and field placements for teacher candidates that affect their decision to accept or reject opportunities to mentor teacher candidates in student teaching experiences. This study will inform teacher education faculty and school administrators about how cooperating teachers perceive clinical placements. When redefining teacher quality indicators, it is important to know how cooperating teachers perceive teacher candidates during clinical experiences. The data derived from this study will assist stakeholders in determining why it is becoming increasingly difficult to place teacher candidates in field and clinical experiences. The evidence can help construct a dialog between universities and school communities directed at improving the outcome of teacher education programming. Armed with this information, teacher education programs can become collaborative and pro-active. This study can also encourage stronger communication between teacher education faculty and community partners.

\section{Research Design}

In 2010, President Barack Obama's administration committed to reevaluate funding streams for NCLB. This effort supported state and local initiatives designed to ensure graduate preparedness for college and the workplace. While a number of teacher preparation studies have examined the issues that surround clinical practice, few have sufficiently documented a vital perception: that of the cooperating classroom teacher. This exploratory study will identify the factors that influence cooperating teachers' decision to mentor teacher candidates.

This mixed methods study incorporating a web-based survey and participant interviews to examine factors that influence PK-12 teachers' decisions to mentor or not to mentor teacher candidates. By using a web-based survey, the researcher investigated teacher perceptions 
concerning teacher candidate mentorship. According to (Sikes, Nixon, Carr, \& ebrary, 2003), non- experimental research is systematic empirical inquiry in which the scientist does not have direct control of independent variables because their manifestations have already occurred or because they are inherently not prejudiced. Because there is little know about this topic, the researcher chose to use exploratory statistics. The goal is to describe phenomena, and the survey is designed gather information from both cooperating and non-cooperating teachers $(\mathrm{H}$. A. Johnson, 2013; P. J. Johnson, 2011). The primary purpose of this descriptive study is to provide an accurate description of the factors that influence cooperating teachers' decision to mentor teacher candidates in the final stage of teacher preparation, student teaching. In addition to the quantifiable questions, the researcher used open-ended questions to collect descriptive data. The researcher felt that additional clarification of the open-ended questions was necessary to understand the data. The researcher conducted a focus group. The focus group was representative of the population involved in the study.

Although, the focus of the study is about the factors that influence teachers' decision to mentor clinical students, it is important to collect data from both cooperating and noncooperating teachers. Collecting data from both cooperating and non-cooperating teachers, will inform clinical faculty and school administrators about the perceived challenges and benefits that influence their decision-making. The data collected will help inform education stakeholders of challenges and strengths of the teacher candidates. All voices are important to this work, because it show the whole picture of mentorship. Additionally, the use of descriptive statistics will give stakeholders hard data to inform their decision-making and program evaluation. This study was designed to utilize quantitative methods with qualitative elements to add an additional layer of understand. Designed to give a voice to the numbers and explain teacher perceptions of the factors that influence their decision to mentor teacher candidates, this 
questionnaire housed open-ended questions. The research approach was selected because of the method's ability to evoke from its subjects a substantive critique regarding the issues (Sikes et al., 2003). Though this approach precludes collection of data from a broadly representative sample, many valid observations can be generalized to apply to circumstances similar to those represented from this study (Sikes et al., 2003).

\section{Setting of the Study}

Moutaskis University requires teacher candidates to complete a 16-week placement in a PK-12 setting. Placing teacher candidates into clinical practice begins by assessing the candidate's needs based on academic records and early field experience placements and evaluations. Students cannot request specific clinical placements, however; students may request general areas or specific counties. Upon receipt of the teacher candidate applications, the Director of Clinical Experiences checks each application to ensure eligibility. Each building coordinator or administrator in the surrounding counties attends a placement meeting. The placement meetings assist both the Director of Clinical Experiences and districts with placements and, give teachers the opportunity to participate in the placement process. Every candidate is required to create a brochure to help all parties involved understand their teacher training experiences and their biographical information and some of their interests. At the placement meetings, candidates provide school districts with brochures and the groups of cooperating teachers determine a match.

Elementary candidates traditionally stay in the same school, but have two placements within that setting, primary and intermediate. Secondary (5-12 licensures) candidates PK-12 candidates collaborate with at least two cooperating teachers, each at different grade levels. Depending on the candidate's licensure area, either they will have an experience at the middle 
school level and at the high school level, or the experience will be at the secondary level (middle school or high school) and at the elementary level.

Upon placement, the candidates are encouraged to contact the cooperating teacher to initiate a conversation about the upcoming experience. This conversation might involve scheduling pre-planning sessions, exchanging information, touring the school grounds, and locating district resources. After this initial contact, the university supervisor visits with the cooperating teacher and the candidate to discuss the outcomes of clinical experience, the teacher education conceptual framework, the university schedule, and any clarifications needed. Sometimes the school administrator chooses to have an orientation or welcome session before the candidates begin the experience. It is necessary to create a harmonious situation for the candidate, the cooperating teacher, the university, the school district, and the children in the classroom.

\section{Population}

Defined as the pool of teachers who could mentor teacher candidates in a public school k12 setting, the population refers to teacher who could potentially serve as cooperating teachers. The population only included potential cooperating teachers. The cooperating-teacher population is 150,82 elementary, 49 secondary, 19 related arts. The non-cooperating teacher population is approximately 1500 and is scattered throughout Moutaskis University's serving area. Even though this population is not considered small, (Lowing, 2011) has suggested that there is little point in sampling in descriptive and exploratory studies. Even though the population is slightly over 1500 , researchers suggest that it is prudent to use responses from the entire population ("Educational research; quantitative, qualitative, and mixed approaches, 4th ed," 2011 4th ed, 2011; Lowing, 2011). Therefore, the researcher used the entire population. 


\section{Data Collection}

The study took place at Moutaskis University, a medium sized balanced arts \& sciences/professions, high graduate coexistence institution in the eastern mid-Atlantic region of the United States. This institution annually graduates approximately 200 education majors. The College of Education within Moutaskis University houses 17 initial certification programs and the largest program is elementary education. Within the undergraduate unit, the office of clinical experiences uses 25 university supervisors and 150 cooperating teachers in an academic year. Ninety percent of the university supervisors are retired schoolteachers, and $10 \%$ are retired principals. Even though the focus of this study is not on university supervisors, it is important to note that retiree may not be as connected to current trend as faculty (Edwin, 2002; Fantozzi, 2012; Hunt, 2011). Recommended by either their building coordinator or school administrator cooperating teachers are categorized as instructional specialists. All of which have a minimum of 3 years classroom experience.

The Teacher Perceptions questionnaire was disseminated via email through Qualtrics. The teachers received the questionnaire at the end of the student teaching semester, and were analyzed using quantitative analysis techniques. The purpose of this analysis is to gain an understanding about the factors that influence teachers' decision to mentor teacher candidates. Demographic data and school designation was collected in this quantitative analysis with openended questions to give teachers the opportunity to share more information about their perception of the factors.

At the end of this semester, the cooperating teachers received a survey link via email. The Director of clinical Experiences reviewed the survey information. Respondents' identities remained anonymous; the participants will be following normal procedural protocol. To get a more accurate picture of the factors that influence teachers' decisions to mentor teacher 
candidates, all eligible teachers received the questionnaires. An e-mail was sent to teachers, through a survey website called Qualtrics, inviting them to complete the survey. I took every precaution to ensure the confidentiality of all respondents who responded to the e-mail invitation to participate in the study. Qualtrics is an approved web-based program from the United States Department of Commerce, and is considered the safest survey site for confidentiality. The participation in the Qualtrics generated questionnaire was voluntary, as the teachers had the opportunity to opt-out of the survey by clicking on the appropriate link. Once they did so, Qualtrics will delete their information. If the respondent chose to take the survey, an anonymous online survey consent form explained the study to the respondent. Each participant received informed consent when the respondent clicks on the survey. Furthermore, if at any time, the respondent chose not to complete the survey, they could opt out. Qualtrics deleted the email information immediately. However, if the respondent did not opt out, but did not complete the survey they were added into the total number, and this is why not all of the questions have the same number of participants reported.

The surveys administered through Qualtrics each have a unique number or identifier added to each questionnaire, so that there is a heightened level of confidentiality. The first email launched during the fourth week of the eight-week placement allowing the respondents plenty of time to complete the survey. If the respondent did not opt-out, but did not complete the questionnaire a reminder notified the teacher two weeks later. A third and final reminder email went two weeks after the second e-mail. The third reminder was the final reminder, because the placement ends in eight weeks. If the respondent did not complete the questionnaire within two weeks of the final remainder their information was deleted from Qualtrics. There are no risks to the respondents through their participation in this study. In addition to the choice to opt-out, 
respondents had the option to share more information about their perceived influential factors through open-ended questions. After participation, the respondents were not debriefed.

\section{Revised Data Collection}

This study was designed with the intent to disseminate a questionnaire via Qualtrics, and to evaluate the data collect from the open-ended questions; however, the information gleaned from the survey lacked depth. The researcher decided that conducting a focus group would be helpful in gaining insight to the unanswered questions. The researcher's background and own assumptions about the placement of teacher candidates might have filtered aspects of this study.

To diminish biases the qualitative researcher fences in biases to diminish the influence of any bias, yet it is difficult for a qualitative researcher to eliminate all biases(Creswell, 2014). Since the researcher worked with the Office of Clinical Experience at Moutaskis University prior to the study, perceptions about the population did exist. Carefully acknowledged to avoid research contamination, the researcher documented all biases before starting the data analysis.

In an attempt to obtain a global point of view, the researcher used both survey and focus groups. Surveys assume that people can quantify how they feel, but sometimes they need to process the information verbally. Therefore, in order to obtain more information in a small and safe group setting to help form thoughts and opinions. Focus groups were conducted. The focus groups revealed a wealth of detailed information and deep insight to the information provided by the survey. Surveys are good for collecting information about people's attributes and attitudes, but because the researcher needed to understand the nuances of each factor at a deeper level a focus group was the solution employed. 
As surmised in Focus groups as qualitative research, the main purpose of focus group research is to draw upon respondents' attitudes, feelings, beliefs, experiences and reactions in a way in which would not be feasible using other methods, for example observation, one-to-one interviewing, or questionnaire surveys. These attitudes, feelings, and beliefs may be partially independent of a group or its social setting, but are more likely to be revealed via the social gathering and the interaction which being in a focus group entails (Morgan, 1993). Compared to individual interviews, which aim to obtain individual attitudes, beliefs and feelings, focus groups elicit a multiplicity of views and emotional processes within a group context. The individual interview is easier for the researcher to control than a focus group in which participants may take the initiative. Compared to observation, a focus group enables the researcher to gain a larger amount of information in a shorter period. Observational methods tend to depend on waiting for things to happen, whereas the researcher follows an interview guide in a focus group. In this sense, focus groups are not natural but organized events. Focus groups are particularly useful when there are power differences between the participants and decision-makers or professionals, when the everyday use of language and culture of particular groups is of interest, and when one wants to explore the degree of consensus on a given topic (Morgan \& Kreuger 1993).

\section{Data Collection Procedures}

From the questionnaire, the researcher collected quantitative and qualitative data, and the focus group interview gave life to the numbers. Cooperating teachers participated in both the questionnaire and the focus group interview. The researcher conducted the focus group interview with cooperating teachers that participate in the survey. 


\section{Teacher Perceptions Questionnaire}

Administered via email through Qualtrics, the researcher disseminated the questionnaire at the end of the student teaching semester, and was analyzed using quantitative analysis techniques. The purpose of this analysis is to gain an understanding about the factors that influence teachers' decision to mentor teacher candidates. Demographic data as well as school designation was collected in this quantitative analysis with open-ended questions to give teachers the opportunity to share more information about their perception of the factors.

At the end of this semester, the cooperating teachers were sent a survey link via email. The Director of Clinical Experiences reviewed the survey information. Although, the data for this study cannot be collected in a way that ensures that respondents' identities are kept anonymous, the participants followed normal procedural protocol. To get a more accurate picture of the factors that influence teachers' decisions to mentor teacher candidates, the surveys were sent to all teachers that teach in schools that host teacher candidates. An e-mail was sent to the teachers, through a survey website called Qualtrics, inviting them to complete the survey. I took every precaution to ensure the confidentiality of all respondents who responded to the email invitation to participate in the study. I used Qualtrics because it is an approved web-based survey program from the United States Department of Commerce, and is considered the safest survey site for confidentiality. The participation in the Qualtrics generated questionnaire was voluntary, as the teachers were given the opportunity to opt-out of the survey by clicking on the appropriate link. Once they did so, Qualtrics will delete their information. If the respondent chose to take the survey, he or she was provided with an anonymous online survey consent form that explains to the respondent what the study is about and how their information will be kept confidential. Informed consent will be given when the respondent clicks on the survey. 
Furthermore, if at any time, the respondent chose not to complete the survey, they could have opted-out, and their e-mail information was deleted from Qualtrics at that time.

The surveys administered through Qualtrics each have a unique number or identifier added to each questionnaire, so that there is a heightened level of confidentiality. The first email was sent out during the fourth week of the eight-week placement allowing the respondents plenty of time to complete the survey. If the respondent did not opt-out, but did not complete the questionnaire, a second e-mail will be sent out two weeks later to remind the respondents to complete the survey. A third and final e-mail was sent out two weeks after the second e-mail to remind respondents to complete any uncompleted survey. The third reminder was the final reminder, because the placement ends in eight weeks, and the respondent's information was deleted from Qualtrics. There are no risks to the respondents through their participation in this study. In addition to the choice to opt-out, respondents had the option to share more information about their perceived influential factors through open-ended questions.

\section{Focus Group Interview}

Conducted during the first 45 minutes of an Instructional Support Enrichment Day (ISE), a second set of data collected included a focus group interview. State Code provides instructional support and enhancement days to facilitate school improvement for educational programs throughout Public Schools. The Office of Institutional Education Programs will provide the same opportunity to ensure the quality of standards for its educational facilities. The participants invited to participate in the focus group were teachers that expressed a desire to share more information through the Qualtrics survey. Eighteen teachers were invited and 14 participated. 
The focus group questions followed a template of pre-determined questions. The interview was initiated to address concerns about school designation, why teachers chose to accept teacher candidates or not, and any information that the teachers felt would be pertinent to the study. These questions were designed to discuss the influences found in the literature review and to offer an opportunity understand the participants' background and perceptions. This approach helped uncover additional findings about all research questions, enriching the content available for analysis. See Appendices $C$ through D to view the interview template.

The researcher and an outside transcriptionist transcribed the focus group interview. Using the recording, both the transcriptionist and the researcher listened to each question and transcribed each participant's response, including all discussion. After the initial transcriptions were completed, the researcher compared both transcribed documents looking for discrepancies, and highlighted them for review. Next, the researcher compared the compiled document with the recording again listening with the intention to make additions or corrections as needed. Finally, the researcher listened to the recording to ensure the attitudes and emotions were included in the final notes. After the transcription of the focus group interview was completed, the researcher followed the procedure below to analyze the data collected (Denzin \& Lincoln, 2013):

1. Read all the answers to a question, looking for patterns and similarities.

2. Entered the comments into an excel spreadsheet separating the comments thematically.

3. Grouped the answers into key points, and then sorted with the Excel sort function.

4. Arranged the categories from largest number of entries to those with the smallest.

5. Summarized the overall response to that question.

6. Selected a few quotes from the transcript that illustrated and provided insights for the summary. 


\section{Instrumentation}

This descriptive study was designed to collect data from PK-12 teachers (appendix B). These data sources established a practical data collection for this study. These data answered the three research questions by a questionnaire, The Teacher Perceptions Survey, delivered through Qualtrics. The researcher disseminated the questionnaires via email 12 weeks into the student teaching placement. The questionnaire consists of demographic questions, open-ended questions, multiple-choice questions, and a Likert-scale. Gleaned from the perceived holes in the data gleaned from the questionnaire, the Focus group interview questions added a layer of understanding to the open-ended questions. The matrix breakdown below maps out each question and delineates the corresponding survey questions. 


\section{Teacher Perceptions Questionnaire Matrix}

\begin{tabular}{|c|c|c|c|c|c|}
\hline \multicolumn{2}{|c|}{ VARIABLE } & Survey item \# & Score Range & $\begin{array}{l}\text { Mathematical } \\
\text { Process }\end{array}$ & Scoring Information \\
\hline \multicolumn{6}{|c|}{ Factors affecting decision to serve as a mentor } \\
\hline RQ1 & $\begin{array}{l}\text { Feelings about teacher } \\
\text { preparation (Moutaskis } \\
\text { University) }\end{array}$ & 17 & $1-5$ & Raw Score & $\begin{array}{l}1=\text { Very Satisfied } \\
2=\text { Satisfied } \\
3=\text { Neutral } \\
4=\text { Dissatisfied } \\
5=\text { Very Dissatisfied }\end{array}$ \\
\hline RQ1 & $\begin{array}{l}\text { Feelings about Moutaskis } \\
\text { University }\end{array}$ & 18 & $1-5$ & Raw Score & $\begin{array}{l}1=\text { Very Satisfied } \\
2=\text { Satisfied } \\
3=\text { Neutral } \\
4=\text { Dissatisfied } \\
5=\text { Very Dissatisfied }\end{array}$ \\
\hline RQ1 & Professional Obligation & $\begin{array}{l}19(1) \\
20\end{array}$ & $\begin{array}{l}1-4 \\
\text { Open Ended }\end{array}$ & Raw Score & $\begin{array}{l}1=\text { No influence } \\
2=\text { Not very important influence } \\
3=\text { Somewhat Important Influence } \\
4=\text { Very important influence }\end{array}$ \\
\hline RQ1 & Time Commitment & $\begin{array}{l}19(2) \\
21\end{array}$ & $\begin{array}{l}1-4 \\
\text { Open Ended }\end{array}$ & Raw Score & $\begin{array}{l}1=\text { No influence } \\
2=\text { Not very important influence } \\
3=\text { Somewhat Important Influence } \\
4=\text { Very important influence }\end{array}$ \\
\hline RQ1 & Overall Preparation & $\begin{array}{l}19(3) \\
22\end{array}$ & $\begin{array}{l}1-4 \\
\text { Open Ended }\end{array}$ & Raw Score & $\begin{array}{l}1=\text { No influence } \\
2=\text { Not very important influence } \\
3=\text { Somewhat Important Influence } \\
4=\text { Very important influence }\end{array}$ \\
\hline RQ1 & Involvement in Preparation & $\begin{array}{l}19(4) \\
23\end{array}$ & $\begin{array}{l}1-4 \\
\text { Open Ended }\end{array}$ & Raw Score & $\begin{array}{l}1=\text { No influence } \\
2=\text { Not very important influence } \\
3=\text { Somewhat Important Influence } \\
4=\text { Very important influence }\end{array}$ \\
\hline RQ1 & Anxiety/Stress & $\begin{array}{l}19(5) \\
24\end{array}$ & $\begin{array}{l}1-4 \\
\text { Open Ended }\end{array}$ & Raw Score & $\begin{array}{l}1=\text { No influence } \\
2=\text { Not very important influence } \\
3=\text { Somewhat Important Influence } \\
4=\text { Very important influence }\end{array}$ \\
\hline RQ1 & $\begin{array}{l}\text { Committed to improving the } \\
\text { field }\end{array}$ & $\begin{array}{l}19(6) \\
25\end{array}$ & $\begin{array}{l}1-4 \\
\text { Open Ended }\end{array}$ & Raw Score & $\begin{array}{l}1=\text { No influence } \\
2=\text { Not very important influence } \\
3=\text { Somewhat Important Influence } \\
4=\text { Very important influence }\end{array}$ \\
\hline RQ1 & Candidate Preparedness & $\begin{array}{l}19(7) \\
26\end{array}$ & $\begin{array}{l}1-4 \\
\text { Open Ended }\end{array}$ & Raw Score & $\begin{array}{l}1=\text { No influence } \\
2=\text { Not very important influence } \\
3=\text { Somewhat Important Influence } \\
4=\text { Very important influence }\end{array}$ \\
\hline RQ1 & Candidate Professionalism & $\begin{array}{l}19(8) \\
27\end{array}$ & $\begin{array}{l}1-4 \\
\text { Open Ended }\end{array}$ & Raw Score & $\begin{array}{l}1=\text { No influence } \\
2=\text { Not very important influence } \\
3=\text { Somewhat Important Influence } \\
4=\text { Very important influence }\end{array}$ \\
\hline
\end{tabular}


CLINICAL PLACEMENT FACTORS

\begin{tabular}{|c|c|c|c|c|c|}
\hline RQ1 & $\begin{array}{l}\text { Candidate's ability to plan } \\
\text { and deliver lesson }\end{array}$ & $\begin{array}{l}19(9) \\
28\end{array}$ & $\begin{array}{l}1-4 \\
\text { Open Ended }\end{array}$ & Raw Score & $\begin{array}{l}1=\text { No influence } \\
2=\text { Not very important influence } \\
3=\text { Somewhat Important Influence } \\
4=\text { Very important influence }\end{array}$ \\
\hline RQ1 & $\begin{array}{l}\text { Opportunity for } \\
\text { professional development }\end{array}$ & $\begin{array}{l}19(10) \\
29\end{array}$ & $\begin{array}{l}1-4 \\
\text { Open Ended }\end{array}$ & Raw Score & $\begin{array}{l}1=\text { No influence } \\
2=\text { Not very important influence } \\
3=\text { Somewhat Important Influence } \\
4=\text { Very important influence }\end{array}$ \\
\hline RQ1 & $\begin{array}{l}\text { Amount of monetary } \\
\text { compensation }\end{array}$ & $\begin{array}{l}19(11) \\
30\end{array}$ & $\begin{array}{l}1-4 \\
\text { Open Ended }\end{array}$ & Raw Score & $\begin{array}{l}1=\text { No influence } \\
2=\text { Not very important influence } \\
3=\text { Somewhat Important Influence } \\
4=\text { Very important influence }\end{array}$ \\
\hline RQ1 & $\begin{array}{l}\text { Consideration of } \\
\text { Mentorship }\end{array}$ & $\begin{array}{l}31 \\
32\end{array}$ & $\begin{array}{l}1,2 \\
\text { Open ended }\end{array}$ & Raw Score & $1=$ No and $2=$ yes \\
\hline \multicolumn{6}{|c|}{ STATUS OF TEACHER'S SCHOOL AS A PD SCHOOL } \\
\hline RQ2 & School's designation & 15 & $1,2,3$ & Raw Score & $1=$ PDS, $2=$ Partner, $3=$ Non-PDS \\
\hline RQ 2 & $\begin{array}{l}\text { Professional Learning } \\
\text { Communities - PDS } \\
\text { Programming }\end{array}$ & 16 & 1,2 & Raw Score & $1=$ No and $2=$ Yes \\
\hline \multicolumn{6}{|c|}{ SELECTED DEMOGRAPHICS } \\
\hline RQ3 & Teacher's Gender & 2 & 1,2 & Raw Score & $1=$ Male $2=$ Female \\
\hline RQ3 & Teacher's Age & 3 & Multiple choice & Fixed & Age ranges \\
\hline RQ3 & Racial Identity & 4,5 & Multiple choice & Fixed & Race \\
\hline RQ3 & Ethnic Identity & 6,7 & $\begin{array}{l}\text { Multiple Choice } \\
\text { Open-Ended }\end{array}$ & Raw Score & $\begin{array}{l}\text { Ethnicity } \\
\text { description }\end{array}$ \\
\hline RQ3 & Degree Level & 8 & Multiple choice & Fixed & \\
\hline RQ3 & Degree Area & 9 & Multiple Choice & Not fixed & \\
\hline RQ3 & Certification area & 10 & Multiple Choice & Not-fixed & \\
\hline RQ3 & Currently Teaching & 11 & Multiple Choice & Fixed & \\
\hline RQ3 & School Size & 12 & Multiple Choice & Fixed & \\
\hline RQ3 & Years of Experience & 13 & Open Ended & & \\
\hline RQ3 & $\begin{array}{l}\text { Experience at Current } \\
\text { School }\end{array}$ & 14 & Open ended & & \\
\hline RQ3 & Mentorship for Moutaskis & 15 & 1,2 & Raw Score & $1=$ No and $2=$ Yes \\
\hline
\end{tabular}




\section{Focus Group Protocol}

The Evaluator: (Script)

Good morning/afternoon!

Thank you for taking the time to meet with us. We will honor your time by making sure that we wrap up in the next 90 minutes. Does anyone mind if we tape record this for our records? We will not share the tapes with the Clinical Experience Staff or your building administrators. I am a researcher, currently completing the requirements for an EdD, and my area of interest is teacher preparation. More specifically, I am researching the factors that influence the decisions of teachers to mentor or not to mentor teacher candidates. Our evaluation is quantitative and qualitative. This means that our primary point is to gather information that will help shape the placement of teacher candidates; and that the information we are collecting is by design is both descriptive and numeric. We have a system for quantifying qualitative information, but for now, we do not need to be concerned with counting thing. We just want your words and your impressions. All information we collect is confidential as to who provided it. For example, we will not disclose who actually participated in this focus group nor will our final report make any attributions for quotes. We hope this encourages you to speak freely. Our evaluation will result in a written report by November 1, 2013. This report will be delivered to my dissertation chair for review before defended to the entire dissertation committee.

Any questions before we start?

1. After reviewing the survey, I noticed that several teachers stated that they participated in Moutaskis University sponsored/facilitated PLC initiatives, but were unsure if they were in a PDS school. Can you speak to why teachers maybe unsure of the PDS/Non-PDS status?

2. After reviewing the data from the questionnaire, I noticed some conflicting answers. In the Likert scale, questions there were distinct delineation of what factors were influential for teachers' decision-making; however, it was difficult if the influences were positive or negative when compared to the open-ended questions. So could you please tell me: 
a. Why do enjoy mentoring teacher candidates?

b. Why don't you like mentoring teacher candidates?

3. Is there anything that I did not ask you that you would like to share with me for the good of the study?

\section{Data Analysis}

Data were analyzed to determine the following: (a) the factors that influence the decision by practicing PK-12 to mentor teacher candidates and (b) are these factors significantly different based on the teachers association with professional development schools and (c) are these factors significantly different based on demographic aspects. SPSS was used to analyze the data from the questionnaire, and yield analysis. First, a measure of central tendency (mean score) and a measure of variability (standard deviation) will be calculated for each standard. Measures of central tendency give a numerical value that is most typical of the values of a quantitative variable, and measures of variability provide information about how spread out or dispersed the data values are (Johnson \& Christenson, 2000). This information provides an overall picture of candidate readiness. The two types of measures of variability I plan to use in my study are the range and standard deviation. The range indicates the difference between the highest and lowest scores. The standard deviation was most appropriate for this study, as all data will be considered when determining the measure of variability. Standard deviation should reveal consistency among stakeholders or whether data correlations would rely on a particular demographic, such as age or education level, that would link the stakeholders. The consistency and reliability determined for data using standard deviations was crucial in proving a correlative relationship.

The measure of the relationship between the influencing factors, demographics, PDS, and Non-PDS affiliation among stakeholders can be determined by using standard deviations, central 
tendencies, and The Pearson product-moment correlation. The Pearson product-moment correlation measure was used to determine whether a relationship exists and to answer the research questions stated.

The open-ended questions and focus group interviews provided additional data to extrapolate either the central tendency of the quantitative data or the outlier data points. The answers to these questions also helped to define interview protocols for the focus group. When the survey was created, the researcher determined that it was impossible to determine how many participants would complete the open-ended questions, the exact nature of analysis was emergent. The smaller data set served as examples of larger points, but will not lend them to supporting specific findings so a focus group interview was employed to dig deeper into the perceptions of teachers.

\section{Assumptions and Limitations}

Designed to gather information about teacher candidate placements from the cooperatingteacher's point of view, this study uncovered a perspective not well represented in the field of teacher education research. There has been a plethora of research conducted about teacher preparation, teacher quality, and teacher induction programs, it is possible the evidence gathered in this study will simply confirm the findings of past studies (Darling-Hammond, 2006a, 2006b; Darling-Hammond, Amrein-Beardsley, Haertel, \& Rothstein, 2012; Darling-Hammond \& Berry, 2006). Nonetheless, because the findings will come from the perspective of cooperating teachers, the study will provide a source of new information. Giving the field a more inclusive view of how teacher effectiveness is perceived, evaluated, and constructed in educational communities. 
The scope of this study was limited to one university's teacher education program in the eastern mid-Atlantic region of the United States that is located in a tri-state area. The majority of the participants lived and worked is a four county radius. Other teacher education programs across the United States could produce different outcomes. Due to the size of the university's teacher education program, the data collection could yield as few as approximately 200 in the data set. With approximately 150 cooperating teachers and 1500 non-cooperating, the total group of teachers is approximately 1600-1650 who were eligible, but only 1245 had viable contact information. The low yield would be the result of a 10 percent return rate from teachers, which was expected given their potential lack of interest in the topic. As classified by Carnegie, the teacher education program used in the study is a part of a university that is classified as a balanced arts \& sciences/professions, high graduate coexistence institution of higher education. It is possible for a larger institution to have different findings; however, this study could prove useful in establishing a baseline for studies conducted in different contexts.

\section{Reliability and Validity}

Triangulation was used to attain reliability of this study. According to Merriam (2014) and Creswell (2014), different sources must be used to create triangulation. To employ triangulation, a researcher collects — multiple sources of data (Merriam-Webster, 2014), such as questionnaire with multiple choice questions, Likert scale, open-ended questions, and focus group interviews. Triangulation enables the researcher to integrate many resources. Using this process, a researcher looks for similar patterns. By checking to see if a pattern is repeatedly, the researcher is essentially determining if the research is reliable(Merriam-Webster, 2014). If several resources establish consistent patterns with the same information, then the researcher is also validating the study (Creswell, 2003; Gall et al., 2003; Merriam, 1998). 


\section{Summary}

This chapter explained both the quantitative and qualitative approaches that guided this study. With the use of different data resources, and the application of the comparative contrast method, this study yielded valid and reliable data. This research design assisted in restricting this study as the researcher attempted to explain the perceptions of teachers concerning teacher candidate mentorship. The following chapter analyzes and presents the results of this research study. Chapter Five details conclusions and suggestions for future research. 


\section{CHAPTER FOUR: FINDINGS}

Presented in this chapter are the findings of the study with the research questions addressed in the order that they were listed in chapter one. To provide an in-depth analysis of the research questions, tables and narrative discussion are included. The organization of this chapter features eight sections. The first section presents a description of the study and the research questions. Following the restatement of the research questions, the next section covers the data collection procedures for the survey and a discussion of the response rate, and a summary of the demographic characteristics of the respondents. This is followed by a discussion

of the findings as they relate to the research questions. Next is the discussion of findings the data revealed in the open-ended questions, and focus group interviews. The chapter concludes with a summary of the findings.

\section{General Information}

This study was designed to determine what factors influence teacher mentorship of teacher candidates, and if there is a relationship between the teachers' association with professional development schools. In addition, relationships were explored between the demographic data of the teachers involved in the study and both variables, in order to determine whether these variables differed according to categorical groupings of the population. There was a desire to understand how cooperating teachers view their role in teacher preparation, particularly in teacher candidate mentorship through clinical experiences. Using The Teacher Perceptions Survey, the researcher analyzed the data in order to measure teacher perceptions toward mentorship. The population consisted of all teachers that taught in Cornwall, Leetonia, Liston, Montrose, Maxwell, Minton, and Wilhelm Counties during the 2012-2013 school years. The findings presented in this chapter highlight the factors and their status as barriers/nonbarriers. 


\section{Research Questions}

The following research questions guided this study.

1. What are the factors that affect the decision by practicing PK-12 teachers to accept placement of teacher candidates in clinical experiences?

2. Are the factors that affect the decision by practicing PK-12 teachers to accept placement of teacher candidates in clinical experiences significantly different based on the teacher's working at a school identified as a professional development school or non- PDS?

3. Are the factors that affect the decision by practicing PK-12 teachers to accept placement of teacher candidates in clinical experiences significantly different based on selected teacher demographics?

\section{Methods}

In June of 2013, teachers in Moutaskis University's direct service area (Cornwall, Leetonia, Liston, Montrose, Maxwell, Minton, and Wilhelm Counties) were invited to participate in the study and to give their open and honest opinions. The contact information for the teachers was compiled from county directories. Some email addresses were unpublished, which left 1245 teachers $(\mathrm{N}=1245)$ who were asked to participate. Of the 1245, 280 teachers began the questionnaire, yielding $239(\mathrm{n}=239)$ useable questionnaires. The unusable questionnaires were either blank or incomplete with major portions of the questionnaire blank. Questionnaire with only demographic information completed or incomplete Likert Scales were unusable. With 239 questionnaires returned and useable surveys out of 1245 , the response rate was $19 \%$. The timing of the study most likely caused this relatively low return rate. The questionnaire was sent out the first week in June 2013, and most of the teachers in Moutaskis University's service area were finished with school by the May 31, 2013.

The survey was delivered via email with a link to the questionnaire. Each participant was asked to provide a name and contact information if the participant wanted to make themselves available for follow-up conversations. The instrument collected data related to demographic 
information of the respondents, the attitudes of the teachers towards mentorship, and school designation (PDS, partner school, or NON PDS).

Used to analyze the data, descriptive statistics and Pearson 2-tailed correlation analyses gave a voice to the numbers. Because the demographic data was binary in nature and did not lend itself to categorization in a meaningful way, the researcher employed the Pearson 2-tailed correlation. The preliminary analysis involved computing the descriptive data from questions 313. The demographic variables explored were gender, ethnicity and race, level of education, area of certification, years of experience, and years in current setting. The demographic data collected did not yield responses that showed a connection to teacher candidate mentorship was affected by gender, ethnicity, and race, level of education, area of certification, years of experience or current teaching setting.

\section{Characteristics of participants}

Obtained from the population, the demographic information painted a picture of the group in terms of gender, race and ethnicity, age range, level of education, grade level taught, and number of years of experience as a teacher. The majority of teachers in the sample were between the ages of 41 to $56+$, white, female, taught elementary school, have a Master's +45 , have been teaching between 7 and 20 years, have mentored teacher candidates from Moutaskis University, and participated in professional learning communities sponsored by professional development school programs (See Table 1 for detailed information).

\section{Researcher Subjectivity}

Because this study is a mixed study, it was imperative to give participants an opportunity to share their opinions and feelings about teacher candidate placements through more than one method. Qualitative research lends itself to observation, listening, and interpreting. The interaction that took place in the Focus Group was organic in nature, but it is important to note 
that the researcher was familiar with the teachers that participated in the interview. The researcher collaborated with the practicing teachers in professional development programming and the placements of teacher candidates. The researcher was intimately involved in the research process and in constructing the results. For these reasons, this study could be considered somewhat subjective, meaning that the results are researcher-dependent. To combat this notion, the researcher relied heavily on the quantitative data gleaned from the questionnaire. The focus group interview added another layer to the data, contributing a rich perspective from the practicing teachers as a way of enhancing the findings.

\section{Major Findings}

The major findings from this study were obtained from the research questions proposed in chapter one:

1. What are the factors that affect the decision by practicing PK-12 teachers to accept placement of teacher candidates in clinical experiences?

2. Are the factors that affect the decision by practicing PK-12 teachers to accept placement of teacher candidates in clinical experiences significantly different based on the teacher's working at a school identified as a professional development school or non- PDS?

3. Are the factors that affect the decision by practicing PK-12 teachers to accept placement of teacher candidates in clinical experiences significantly different based on selected teacher demographics?

Those questions examined the factors that influence teacher candidate placements and mentorship by exploring eleven dimensions that might influence teachers' decisions and association with professional development schools. The Teacher Perceptions survey measured the attitudes of teachers toward teacher candidate mentorship through a rating scale and corresponding open-ended questions. Although the standard deviation was not used in the data reporting, the researcher calculated central tendency for each response. Created with the literature in mind, the 11 influential statements, beginning with statement 20(a)-20(k), asked 
teachers to cite significant influences that affect their decision to mentor teacher candidates. To measure the degree of agreement with each statement, the questionnaire gave teachers the opportunity to rate their perceptions with a four-point variation ranging from very important influence to no influence.

\section{Analysis}

Analysis of the data collected from the survey consisted of descriptive statistics, correlations, and multiple-regression analysis. The purpose of the multiple-regression analysis was to determine if there was an interaction among the factors. There were no statistically significant relations discovered by this process. For a more meaningful understanding, the researcher used descriptive statistics to parse the demographic data. Although the demographic data do not directly answer a research question, the data were analyzed for the mean, median, and standard deviation to help understand the characteristics of the participating teachers. Although the mean was calculated, it was not meaningful because a large portion of the data was bivariate. To add understanding to the data collected, a focus group of teachers was convened. The focus group consisted of both teachers that are willing to and not willing to accept teacher candidates. The findings are displayed in TABLE 1. 
TABLE 1 Demographics of Population

Number

Gender

Female

195

Male

44

Race

American-Indian or Native

Alaskan

Asian 2

African American or Black 2

White

205

Ethnicity

Hispanic or Latino

Non-Hispanic or Latino

2

186

Age Range

25-30

30

31-35

31

$36-40$

24

41-45

24

37

35

27

46-50

51-55

$56+$

Level of Education

$\mathrm{BA} / \mathrm{BS}$

11

$\mathrm{BA} / \mathrm{BS}+15$

59

MA/MS

13

MA/MS +15

27

$\mathrm{MA} / \mathrm{MS}+30$

24

76

3

MA/MS +45

Ed.Ms.

Grade Level Taught

Pre-school

13

13

10

10

15

11

4 25

5

11

10

32

Percent

82

18

0.4

\section{1}

1

86

1

15

15

1

11 
$\begin{array}{lll}\text { Elementary School } & 93 & 47\end{array}$

Middle School $\quad 45$

61

High School

Years Teaching Experience

0

$1-3$

4-6

$7-10$

$11-15$

$16-20$

21-30

$30+$
23

31

15 7

13

18

11

10

17

9

\section{Research Question \#1}

\section{What are the factors that affect the decision by practicing PK-12 teachers to accept placement of teacher candidates in clinical experiences?}

The first research question was addressed via Likert scale. Respondents indicated very important influence, somewhat important influence, not a very important influence, or no influence for each statement. A ranking score was determined using a simple multiplication scheme: very important influence (4), somewhat important influence (3), not a very important influence (2), or no influence (1). The data were tabulated to determine the most influential factor. The second research question was addressed through the same ranking system, but the respondents were separated and analyzed according to their schools designation PDS or NonPDS. Each group self-identified, and the largest identifying group was the unsure category. The third and final research question was addressed through correlation statistics. The characteristics of the respondents were compared to the influential factors and significance was determined by using a Pearson 2-tailed correlation coefficient. 
Participants were asked to rate eleven factors identified in the literature as being factors that influence the decision making of teachers when they consider mentoring teacher candidates in the final stage of clinical experience commonly referred to as student teaching or internship. Using a Likert scale respondents indicated very important influence, somewhat important influence, not a very important influence, or no influence for each statement. A ranking score was determined using a simple multiplication scheme and an analysis of these scores revealed the factors ranked in order form most influential to least influential were;

Commitment to improving the field of education

Contribution to preparation of teacher candidates

Involvement in teacher candidate preparation

Teacher candidates exhibit professionalism

Professional obligation

Candidates prepared with content knowledge

Opportunity to sharpen my professional skills

Effective instructional delivery

Time commitment

Anxiety / stress

\section{Lack of monetary compensation}

From this ranking, it is clear that the most influential factors in teachers' decisions to accept placements were those factors that provided teachers with personal satisfaction or were intrinsically satisfying in nature. This data are displayed in Table 2 below. The first column lists the factors that the teachers ranked. The second column indicates the number of the participants 
CLINICAL PLACEMENT FACTORS 58

that responded to each question. Because the survey was not designed to force responses, not all of the respondents answered all of the questions. The third through sixth columns shows how the participants scored each factor. The seventh column gives each factor a weighted score, which was calculated by assigning a point value to each rating (very important - four, somewhat important - three, not very important - two, not influential - one.) Lastly, the final column shows the ranking for each factor. Table 2, is representative of the data collected for RQ1. 
TABLE 2: Ranked influential factors

Influential Factors

\begin{tabular}{|c|c|c|c|c|c|c|c|}
\hline & $\mathrm{N}$ & $\begin{array}{l}\text { Very } \\
\text { important }\end{array}$ & $\begin{array}{l}\text { Somewhat } \\
\text { important }\end{array}$ & $\begin{array}{l}\text { Not very } \\
\text { important }\end{array}$ & $\begin{array}{l}\text { Not } \\
\text { influential }\end{array}$ & $\begin{array}{l}\text { Weighted } \\
\text { Score }\end{array}$ & Rank \\
\hline \multirow{2}{*}{$\begin{array}{l}\text { Commitment to Improving the } \\
\text { Field of Education }\end{array}$} & \multirow[t]{2}{*}{173} & 125 & 39 & 6 & 3 & \multirow[t]{2}{*}{638} & \multirow[t]{2}{*}{1} \\
\hline & & 72.2 & 22.5 & 3.5 & 1.7 & & \\
\hline \multirow{2}{*}{$\begin{array}{l}\text { Contribution to teacher } \\
\text { preparation }\end{array}$} & \multirow[t]{2}{*}{173} & 110 & 55 & 8 & 0 & \multirow[t]{2}{*}{629} & \multirow[t]{2}{*}{2} \\
\hline & & 63.6 & 31.8 & 4.6 & 0.0 & & \\
\hline \multirow{2}{*}{$\begin{array}{l}\text { Involvement in teacher } \\
\text { candidate preparation }\end{array}$} & \multirow[t]{2}{*}{173} & 101 & 58 & 12 & 2 & \multirow[t]{2}{*}{616} & \multirow[t]{2}{*}{3} \\
\hline & & 58.3 & 33.5 & 6.9 & 1.1 & & \\
\hline \multirow{2}{*}{$\begin{array}{l}\text { Teacher Candidate exhibits } \\
\text { professionalism }\end{array}$} & \multirow[t]{2}{*}{173} & 97 & 68 & 7 & 1 & \multirow[t]{2}{*}{614} & \multirow[t]{2}{*}{4} \\
\hline & & 56.0 & 39.3 & 4.0 & 0.6 & & \\
\hline \multirow[t]{2}{*}{ Professional Obligation } & \multirow[t]{2}{*}{173} & 94 & 52 & 15 & 12 & \multirow[t]{2}{*}{589} & \multirow[t]{2}{*}{5} \\
\hline & & 54.3 & 30.0 & 8.6 & 6.9 & & \\
\hline \multirow{2}{*}{$\begin{array}{l}\text { Candidate prepared with } \\
\text { content knowledge }\end{array}$} & \multirow[t]{2}{*}{173} & 79 & 72 & 16 & 6 & \multirow[t]{2}{*}{586} & \multirow[t]{2}{*}{6} \\
\hline & & 45.7 & 41.6 & 9.2 & 3.5 & & \\
\hline \multirow{2}{*}{$\begin{array}{l}\text { Opportunity to sharpen } \\
\text { professional skills }\end{array}$} & \multirow[t]{2}{*}{173} & 85 & 61 & 18 & 9 & \multirow[t]{2}{*}{586} & \multirow[t]{2}{*}{7} \\
\hline & & 49.1 & 35.2 & 10.4 & 5.2 & & \\
\hline \multirow{2}{*}{$\begin{array}{l}\text { Candidate prepared to plan } \\
\text { and deliver lessons }\end{array}$} & \multirow[t]{2}{*}{171} & 72 & 83 & 14 & 2 & \multirow[t]{2}{*}{581} & \multirow[t]{2}{*}{8} \\
\hline & & 42.1 & 48.5 & 8.1 & 1.1 & & \\
\hline \multirow[t]{2}{*}{ Time Commitment } & \multirow[t]{2}{*}{172} & 54 & 61 & 41 & 16 & 538 & 9 \\
\hline & & 31.4 & 35.4 & 23.8 & 9.2 & & \\
\hline Anxiety/Stress & 173 & 23 & 59 & 60 & 31 & 480 & 10 \\
\hline & & 13.3 & 34.1 & 34.7 & 17.9 & & \\
\hline Monetary compensation & 173 & 17 & 37 & 50 & 69 & 389 & 11 \\
\hline & & 9.8 & 21.4 & 28.9 & 39.9 & & \\
\hline
\end{tabular}




\section{Summary of Qualitative Data}

Participants were asked to explain how the factors influenced their decision to mentor teacher candidates, and several of the participants gave narrative descriptions of their perceptions of teacher candidate mentorship. This section is comprised of a brief summarization of each open-ended question, and those descriptions are followed by a summary of the statements as a whole. Additionally, as the researcher unpacked the data collected there were some themes that emerged that spoke directly to the heart of teaching. Carol Gilligan shares that ethics and caring is a part of true teaching (Steinberg \& Harvard Univ, 1992). The themes that emerged echoed her focus on caring and empathy in the teacher's personality.

Statement 1: I consider it a professional obligation (Question 21). Of the teachers who participated in this survey, 146 out of 173 or $84 \%$ stated that professional obligation positively influenced their decision to mentor teacher candidates. The mean was calculated on a scale of 14, and was 1.68 with a standard deviation of .90 ; this indicates that the professional obligation influences teachers' decision to mentor. In the open-ended questions, teachers commented:

$>$ I consider it a professional obligation and expect no compensation.

It has been an overall positive experience in the past, and I feel the professional obligation to help teacher candidates become teachers, and I learn from the experience

$>$ As stated above, I consider it a professional obligation to support any new teachers. Teacher attrition rates are high and I would like to guard against losing good quality educators

Statement 2: It is a time commitment (Question 22). Of the teachers that participated in the survey, 115 out of 172 or $67 \%$ agreed that mentoring teacher candidates is a huge time commitment. Thirty-one percent expressed that the time commitment influenced their decision 
to mentor teacher candidates, but $58 \%$ felt that the time commitment was worth it especially if this commitment improved the field of education. The mean was calculated on a scale of 1-4, and was 2.11 with a standard deviation of .96; this indicates that time commitment influences teachers' decision to mentor. In the open-ended questions, teachers commented:

$>$ Time commitment is not a factor, your there to do a job and help others

$>$ Most of my teachers feel the time commitment for mentoring teacher candidates is not an issue.

$>$ The time commitment is not an issue as long as everyone is improving the lives of the students.

I do not mind the time commitment. I do, however, find it difficult to have a teacher candidate in the first half of the first semester of the first semester as it is the first school experience for many of my students and I need that time to establish routines.

$>$ The time commitment is not really a factor for me but I do prefer placements that are not in the first 9 weeks of the school year. The opening weeks are precious time for establishing routines, procedures, and rapport. Selfishly, I do not want to lose it.

I am not bothered by the time commitment when the candidates are sound

Major deterrent ... we play an integral role in mentoring these candidates and while a thank you is appreciated it truly doesn't compensate for the risks we take professionally especially as testing becomes more and more critical . . . also it is a HUGE time commitment outside of the school day for both candidate and mentor . . . time away from my family that they are more ok with if I receive compensation outside of a thank you that really doesn't register or mean anything to them . . . all my kids know is that Daddy's gone working with a teacher and not here with me

\section{Statement 3: I can contribute to the overall preparation of teacher candidates}

(Question 23). Of the teachers that participated in the survey, 165 out of 173 or $95 \%$ of the teachers mentor teacher candidates because they feel that they can contribute to the preparation or teachers. $62 \%$ of the teachers that participated in this survey felt that candidates were 
prepared for student teaching, and this was a plus when deciding to mentor teacher candidates. The mean was calculated on a scale of $1-4$, and was 1.41 with a standard deviation of .58 ; this indicates that teachers' respect the opportunity to contribute to teacher candidate preparation, which influences teachers' decision to mentor. In the open-ended questions, teacher commented:

It is beneficial for me to see how the preparation of candidates on the university side connects or disconnects with what is actually occurring in classrooms. I think there are still gaps. This is why I like working with PDS to ensure gaps are closed and candidates receive a streamlined route from university to classroom.

$>$ Candidates need to be preparing to work with students and have a deep understanding and usage of curriculum. They truly need to utilize basic skills to be able to teach elementary school. Some candidates have poor usage of grammar and do not have skills to communicate with students. I am able to teach candidates routines, procedures and classroom management strategies, but I should not have to teach them how to use correct English. Educators are models for children. We must produce quality student candidates.

Statement 4: I can be involved in teacher candidate preparation (Question 24). Of the teachers that participated in the survey, 159 out of 173 or $92 \%$ of the teachers mentor students because they believe that that have something to offer. Seventy-Three percent of the teachers that participated in this survey valued their involvement in teacher preparation and decided to mentor teacher candidates because of professional obligation, personal satisfaction and to sharpen their skills. The mean was calculated on a scale of $1-4$, and was 1.51 with a standard deviation of 0.68 ; this indicates that teachers' want to be involved in teacher candidate 
preparation, which positively influences teachers' decision to mentor. In the open-ended questions, teachers commented:

Being involved with teacher preparation is a wonderful way to help the candidates be ready for the classroom. I never want to let a candidate out of my classroom without being confident that they could teach or sub in their own classroom the next day.

$>$ I have had both good and very poor candidates in the past. Sadly, the latter (due mostly to lack of self-discipline, maturity, work ethic, et. al) has influenced my discontinuation.

$>$ I have only been teaching 9 years, so I still vividly remember how important the field experiences and student teaching time was to me. What a student learns in class and what they experience in a real classroom are two different things, so I hope to help my teacher candidates experience the "real" classroom planning experiences.

I believe that teacher candidates need to have classroom experience beginning the first year they are in school. To get the classroom experience as they prepare to graduate may be too late for them to decide they have no real passion for the classroom. Each semester should have a classroom experience.

\section{Statement 5: There is anxiety/stress associated with mentoring teacher candidates}

(Question 25). Of the teachers that participated in the survey, $47 \%$ of the teachers believe that stress is a factor that causes them to re-think mentorship, but $91 / 173$ or $53 \%$ of the teachers believe that stress is not a factor that influences mentorship. Sixty-five percent of the teachers that participated in this survey acknowledge that there is stress/anxiety associated with mentorship, but do not believe that the stress or anxiety influence their decision to mentor teacher candidates. The mean was calculated on a scale of $1-4$, and was 2.57 with a standard deviation of .93; this indicates that teachers' do not believe that stress or anxiety is an influential 
factor when they are deciding to mentor teacher candidates. In the open-ended questions, teachers commented:

Accepting a teacher candidate can lead to stress -- if the individual has subpar content knowledge, poor classroom management and lacks true commitment to the profession and the kids. This certainly weighs heavy on me before accepting a teacher candidate.

$>$ I only have anxiety if the teacher candidates are not ready to be in a classroom... thus far this has only happened once at our school.

$>$ Overall, it does not hinder this decision. This past year it felt as if the supervisor did not truly value my professional views to the point of questioning my procedures and routines. She also spent a great deal of time comparing the candidates, as well as myself to her daughter who is a teacher in the county. This did not help to create a calm working relationship.

I agreed to take on a teacher candidate this fall, but I have felt some anxiety over the decision. I don't know anything about the person that is walking into my classroom. I think these needs to be fixed. This was also an influence when I completed my own student teaching. I didn't know anything about my host teacher so I had no idea what to expect from him.

\section{Statement 6: I am committed to improving the field of education (Question 26). Of}

the teachers that participated in the survey, $95 \%$ of the participating teachers felt a deep commitment improving the field of education. Seventy-two of the teachers that completed this survey believed that personal commitment to improving the field of education was very important, and influenced them positively when deciding to mentor teacher candidates. The mean was calculated on a scale of $1-4$, and was 1.35 with a standard deviation of .63; this 
indicates that teachers' feel strongly about improving the field of education through teacher candidate mentorship. In the open-ended questions, teachers commented:

As stated previously, when I was involved in the re-evaluation of the MU studentteaching practices and expectations, I felt intrinsically motivated to participate in the teacher candidate program. Also, I feel that the field of education is very murky and muddled with contradictions, so I do feel that it benefits teacher candidates when they have a teacher mentor who can help navigate them through their first real experience as a classroom teacher.

$>$ I am very committed. As mentioned before, if I have a busy schedule and too many projects, I may not be a supervising teacher, but would still have them in seminar.

Any job is only as good as those who choose to do it. If we hope to see excellence, we must put forth that level of performance. Teaching a solid work ethic will help to insure a future of excellence.

\section{Statement 7: The teacher candidates come prepared with appropriate content}

knowledge (Question 27). Of the teachers that participated in the survey, $87 \%$ of the participating teachers felt that teacher candidate preparedness is a factor that influences their desire to mentor teacher candidates, but the open-ended questions show that teacher find the students to be appropriately prepared. Thirty-eight percent of the participants that answered the open-ended questions felt that lack of content knowledge made it harder for them to commit to mentorship especially when they are unsure of the candidate's content knowledge. Although $48 \%$ reported that lack of content knowledge is not an influential factor when deciding to mentor students, they still chose to mentor to help students become more prepared. The mean was calculated on a scale of $1-4$, and was 1.71 with a standard deviation of .78; this indicates that 
CLINICAL PLACEMENT FACTORS 66

content knowledge is a factor that could be a positive or negative influence depending mostly on the level and content area. In the open-ended questions, teachers commented:

At the secondary level, content knowledge is essential to student success. I have had some teacher candidates who had a poor knowledge of their subject matter, which has made me leery of accepting a teacher candidate. I also have found that teacher candidates only want to teach to their strengths. Unfortunately, CSOs dictate what subject matter is taught per grade level, not personal preference.

How can one teach another to do something well if the teacher is not knowledgeable or can't transfer the skill? Impossible. Therefore, the candidate must master the content.

If content knowledge is lacking, we cannot teach it during the teacher candidate experience. That should be addressed before students are placed.

Having a teacher candidate that has a sound understanding of content knowledge is always a plus. This makes the entire teacher candidate process smoother and gives the teacher a sense of being able to let go in the classroom.

Statement 8: Teacher candidates exhibit professionalism (Question 28). Of the teachers that participated in the survey, $95 \%$ of the participating teachers felt that professionalism is important and influences their decision to mentor teacher candidates. Fiftysix percent of the teacher that answered the open-ended questions believed that professionalism is influential to their decision making when considering inviting teacher candidates into their classrooms. The mean was calculated on a scale of $1-4$, and was 1.49 with a standard deviation of .61; this indicates that professionalism is a factor that could be a positive or negative influence. In the open-ended questions, teachers commented: 
Professionalism is important, but it is not an issue that I dwell on before accepting a teacher candidate. Plus, I feel that the perception of professionalism is extremely subjective, especially with such varying school cultures and environments.

I'm disappointed by the lack of professionalism...cell phones should be an absolute no and dress is too casual

Teacher candidates should have the demeanor to be in the classroom and interact with students; this means they should not be overly timid or overly aggressive.

Knowing that we can trust them around young students help ease our fears. Watch them interact with and instruct those shows us that they may become great teachers

\section{Statement 9: The teacher candidates come prepared with the ability to plan and}

deliver lessons effectively (Question 29). Of the teachers that participated in the survey, $91 \%$ of the participating teachers felt that the ability to plan and delivery is influential when deciding to mentor teacher candidates. Ninety-two percent of the teachers that participated in this survey and answered the open-ended questions believed that mentoring teacher candidates sharpened their skills, and kept them fresh. The mean was calculated on a scale of $1-4$, and was 1.68 with a standard deviation of 0.67 ; this indicates that planning and delivery is a factor that could be a positive or negative influence. Forty-six percent of the teachers that answered the open-ended questions believe that teacher candidates were not prepared to write lesson plans in a realistic fashion. The teachers' comments follow:

Again, this is a very important issue to consider before accepting a teacher candidate. I would like to say that this is the most important issue to consider since it directly impacts student learning, but rarely are sample lessons/unit plans submitted to me to preview before I accept a teacher candidate. After having a bad experience with a teacher 
candidate, who was lacking in her content knowledge, and consistently constructed poor lesson plans, I did not accept a teacher candidate the following school year. Therefore, poor lesson planning and instructional delivery can taint my perception of teacher candidates and impact my acceptance of another.

The key here is delivering. The best plans are worthless if the candidate cannot teach them. Thinking on their feet combined with an understanding of what the goals of the lesson contain is paramount.

$>$ A plan is very important as an outline as to where you are going and what and how you plan to achieve your goals. But more important is thinking on your feet and implementing your plan in a clear, fun, organized way. I want to help them to learn how to do that.

I feel that MU goes a bit overboard at times with lesson planning requirements but I understand that a teacher candidate must learn the process. Those extensive lesson plans I see teacher candidates writing, in my opinion, are unrealistic to the actual day-to-day classroom experience.

\section{Statement 10: It is an opportunity for me to sharpen my own professional skills}

(Question 30). Of the teachers that participated in the survey, $84 \%$ of the participating teachers agreed that mentorship sharpens their skills. Ninety-two percent of the teachers that participated in this survey believed that mentoring teacher candidates sharpened their skills, and kept them fresh. The mean was calculated on a scale of $1-4$, and was 1.72 with a standard deviation of 0.86; this indicates that the teachers believed that the opportunity to participate in programming associated with teacher candidate preparation and mentorship sharpens their skills. In the openended questions, teachers commented: 
I do not feel that accepting a teacher candidate has a huge impact on time, other than the loss of some personal and team prep time, which ends up being devoted to collaboration and reflection with the teacher candidate. Overall, I do not let the issue of time impact my decision to accept a teacher candidate.

For the period of time that the candidate works in my classroom, I have the additional consideration of another teacher, which takes time.

It does not influence my decision. Any time that I take planning with the teacher candidate is time that I would have spent planning anyway. Any time that I need to fill out evaluation forms is made up while the teacher candidate is teaching.

The time factor is a huge issue, considering the time constraints of our daily schedule. We have certain content area standards which must be met and with the least amount of interruption.

\section{$\underline{\text { Statement 11: I do not receive monetary compensation for mentoring teacher }}$}

candidates (Question 31). Of the teachers that participated in the survey, $68 \%$ of participants felt that monetary compensation does not influence the decision to mentor teacher candidates. $67 \%$ of the teachers that participated in this survey felt that the lack of monetary compensation was not an influential factor when they were deciding to mentor students, and that the benefits of partnering with Moutaskis University was a plus. The mean on a scale of $1-4$, was 2.99 with a standard deviation of 1.00; this indicates that the teachers believed that the lack of monetary compensation does not influence their decision to mentor teacher candidates. Additionally, the open-ended questions revealed that teacher feel that Moutaskis does not view their role as important as the other stakeholders do because they are not offered compensation. In the openended questions, teachers commented: 
I feel that teachers who mentor should be compensated. That being said, some teachers would participate only for the money and may not be the best mentors. We need some very to be sure that the best teachers are mentors and that they are paid for it.

Sometime of compensation would certainly be nice, even something simple like a $\$ 25$ gift card to Office Depot, etc. However, compensation does not affect my decision to mentor teacher candidates.

I am paid other ways. I haven't been in education long enough to say, "We used to get paid for taking teacher candidates!"

Sometimes it is very time consuming especially when you are the person that spends most of the time with the teacher candidate.... The university supervisors come in two maybe three times at the most and receive compensation. I know that the student's need the experience and will probably always be a mentor however maybe giving a gift certificate for a dinner or coffee shop might make us feel at least a little appreciated :)

As most educators would echo, teaching is a work of heart. From the comments, it is clear that most of the teachers surveyed believe wholeheartedly that teaching requires effort, dedication, love, and compassion. Many aspects of education have changed over the past decade, but one thing has not: the public does not see Teachers as professionals, and this is unfortunate. This lack of professional visibility seems to be one of the reasons that teachers are offended with the idea is little or no compensation. Carol Gilligan believes that emotional maturity and caring is what sets good teachers apart (Gosselin, 2003). Teaching is a work of heart is the tag phrase, but it is real. The open-ended questions, the focus interview and even the questionnaire leads the researcher to believe that teachers take their job seriously, and fine offense when others do not. The notion that teaching is easy is offensive and teachers want to make sure that teacher 
candidate realize the work that it put into effective teaching. It is understandable that teachers are leery of candidates that are not prepared to teach lesson on time, or seem to lack work ethic. Mentorship is about nurturing a new class of teachers, but several of the participants believed that real-life classroom experiences are beneficial to candidates because it shows true expectation. Additionally, often overlooked and equally important components of good teaching: skill, content knowledge, dedication, and experience. With the induction of PDS, teachers have opportunities to share expertise and this collaborative work brings academic status. Overall, there is a struggle for teachers to be seen and to be validated as professionals. The participants surveyed shared a perspective of commitment, but even the most contented teachers voiced a feeling of being unappreciated.

\section{Focus Group Findings}

The focus group interview revealed that teachers enjoyed mentoring students because it gave candidates real-world preparation, and gives teachers the opportunity to share "tricks of the trade" that the university classes do not teach them, and lets the candidates see that teaching forces them to be flexible and adjust often. It is not a perfect world. Teachers also reported that they had positive experiences during their student teach, and the wanted to give that back to someone else. Additionally teachers reported that mentoring teacher candidates keeps them on track, and helps them sharpen their skills and stay fresh. Conversely, some teachers were not willing to mentor teacher candidates. Teachers that were unwilling to mentor teacher candidates were very vocal, and cited several reasons such as:

$>$ Mentoring teacher candidates at the beginning of the year is too difficult

I do not have time to re-teach teacher candidates basic skills

I have a hard time telling them they should not be a teacher

I have a hard time dealing with the incompetence 
At the beginning of the year it is hard, but when preparing for WESTEST its risky business

$>$ Teacher candidates are not willing to put in the work or effort to be teachers Candidates often refuse to correct behaviors and lack classroom management skills In summary, the qualitative data paints a picture of why teacher are willing to support teacher preparation by teacher candidate mentorship. Themes emerged from both the focus group and the open-ended questions that referred to the lack of effort and dedication of the teacher candidates. Not only do in-service teachers have expectations that teacher candidates increase student achievements, but they also want to see that the candidates have the heart for teaching. It is an expectation that the candidates come early and stay late because this relates back to the heart of teaching. Additionally, the majority, 92\%, of the teachers surveyed said that they are willing to mentor teacher candidates. If this is the case, what is really affecting the limited amount of placements? The data suggest several reasons:

$>$ Principals make placement decisions, and only place students with their friends

$>$ Personality conflicts

Teachers are given other responsibilities

Administrators lock-out a school (usually due to school designation)

Incentives or tokens or appreciation for schools and/or individuals are limited

\section{Connection to the Literature}

Mentoring student teachers is recognized within the profession as an important characteristic of teaching excellence, and even as a professional obligation. Supporting a student teacher provides the cooperating teacher with the opportunity to influence the future of the teaching profession in a practical way that ensures they have a significant role in improving the quality of new graduates (Cavanagh \& Prescott, 2011). If cooperating teachers are master 
teachers with well-developed classroom practice they can impart wisdom to teacher candidates, and this is an optimal situation (McCann, 2012). In fact, most educators believe that it is a teacher's responsibility to nurture the next generation of the profession and develop excellent new teachers for the future (McCann, 2012).

Eidger reflects on the responsibilities of the cooperating teacher, and she submits that the university supervisor and the cooperating teacher must work together to provide a quality student teaching experience. Student teachers need to be adequately prepared to meet obligations of becoming a true professional, and both of the professionals must feel a sense of obligation and responsibility not only to the teacher candidate, but also to the field of education (Ediger, 2009).

Even though it was cited that dealing with incompetence was an issue for some practitioners, most noted that they realize the teacher candidates are still students (Hogan, 2011; Russell-McKenzie, 2009; Siwatu, 2011). Being mindful that clinical experience refers to the final placement that teacher candidates have prior to graduation, most practitioners assume the responsibility of shaping and molding the candidate that has been placed in their classroom. The literature reports that this placement along with the next three years teaching is the most formative process of pre-service and novice teachers (L. Evans, 2010; Nolan \& Palazzolo, 2011; Weimer, 2011).

\section{Research Question \#2}

Are the factors that affect the decision by practicing PK-12 teachers to accept placement of teacher candidates in clinical experiences significantly different based on the teacher's working at a school identified as a professional development school or non- PDS?

A ranking score was determined using a simple multiplication scheme and an analysis of these scores revealed the factors ranked in order form most influential to least influential were:

Commitment to improving the field of education 
$>$ Contribution to preparation of teacher candidates

$>$ Involvement in teacher candidate preparation

$>$ Teacher candidates exhibit professionalism

$>$ Professional obligation

$>$ Opportunity to sharpen my professional skills

Effective instructional delivery

$>$ Candidates prepared with content knowledge

$>$ Time commitment

$>$ Anxiety/ stress

Lack of monetary compensation

From this, ranking teachers that participate in professional development school programming have similar feelings about mentoring teacher candidates. The most influential factors are reported in the Table 3 below. The first column lists the factors that the teachers were given to rank. The second column shows the number of the participants that responded to the question. Because the survey did not require the participants to answer all questions, not all of the participants answered all of the questions. The third through sixth columns shows how the participants scored each factor. The seventh column gives each factor a weighted score, which was calculated by assigning a point value to each rating (very important - four, somewhat important - three, not very important - two, not influential - one.) Lastly, the final column shows the ranking for each factor. Similarly, a ranking score was determined using a simple multiplication scheme and an analysis of these score revealed the factors that teachers that were not associated with professional development schools (PDS) were ranked in order form most influential to least influential were;

\section{Commitment to improving the field}


$\square$ Contribution to teacher preparation

$\square$ Involvement with teacher preparation

$\square \quad$ Teacher candidate professionalism

$\square$ Professional obligation

$\square$ Opportunity to sharpen skills

$\square \quad$ Effective instructional delivery

$\square$ Teacher candidate content knowledge preparation

$\square$ Time commitment

$\square \quad$ Anxiety /Stress

$\square \quad$ Lack of monetary compensation

From this, ranking teachers that do not participate in professional development school programming have similar feelings about mentoring teacher candidates. The most influential factors are reported in the table 3 . 
TABLE 3 Influential Factors as ranked by teachers from PDSs

N Very Somewhat Not very Not Weighted Rank important important important influential Score

\begin{tabular}{|c|c|c|c|c|c|c|c|}
\hline \multirow{2}{*}{$\begin{array}{l}\text { Commitment to Improving } \\
\text { the field }\end{array}$} & \multirow[t]{2}{*}{47} & 40 & 6 & 1 & 0 & \multirow[t]{2}{*}{181} & \multirow[t]{2}{*}{1} \\
\hline & & 85.1 & 12.8 & 2.1 & 0 & & \\
\hline \multirow{2}{*}{$\begin{array}{l}\text { Contribution to Teacher } \\
\text { Preparation }\end{array}$} & \multirow[t]{2}{*}{47} & 34 & 12 & 1 & 0 & \multirow[t]{2}{*}{175} & \multirow[t]{2}{*}{2} \\
\hline & & 72.3 & 25.5 & 2.1 & 0 & & \\
\hline \multirow{2}{*}{$\begin{array}{l}\text { Involvement to Teacher } \\
\text { Preparation }\end{array}$} & 47 & 32 & 13 & 1 & 1 & \multirow[t]{2}{*}{171} & \multirow[t]{2}{*}{3} \\
\hline & & 68.1 & 27.7 & 2.1 & 2.1 & & \\
\hline \multirow{2}{*}{$\begin{array}{l}\text { Teacher Candidate } \\
\text { Professionalism }\end{array}$} & \multirow[t]{2}{*}{47} & 28 & 18 & 1 & 0 & \multirow[t]{2}{*}{169} & \multirow[t]{2}{*}{4} \\
\hline & & 59.6 & 38.3 & 2.1 & 0 & & \\
\hline \multirow[t]{2}{*}{ Professional obligation } & \multirow[t]{2}{*}{47} & 28 & 14 & 3 & 2 & \multirow[t]{2}{*}{165} & \multirow[t]{2}{*}{5} \\
\hline & & 59.6 & 29.8 & 6.4 & 4.26 & & \\
\hline \multirow{2}{*}{$\begin{array}{l}\text { Teacher Candidate content } \\
\text { knowledge preparation }\end{array}$} & \multirow[t]{2}{*}{47} & 21 & 21 & 2 & 3 & \multirow[t]{2}{*}{156} & \multirow[t]{2}{*}{6} \\
\hline & & 44.7 & 44.7 & 4.26 & 6.4 & & \\
\hline \multirow{2}{*}{$\begin{array}{l}\text { Effective instructional } \\
\text { delivery }\end{array}$} & \multirow[t]{2}{*}{47} & 15 & 30 & 2 & 0 & \multirow[t]{2}{*}{156} & \multirow[t]{2}{*}{7} \\
\hline & & 31.9 & 63.8 & 4.26 & 0 & & \\
\hline \multirow{2}{*}{$\begin{array}{l}\text { Opportunity to sharpen } \\
\text { skills }\end{array}$} & \multirow[t]{2}{*}{47} & 22 & 18 & 4 & 2 & \multirow[t]{2}{*}{156} & \multirow[t]{2}{*}{8} \\
\hline & & 46.8 & 38.3 & 8.5 & 4.26 & & \\
\hline \multirow[t]{2}{*}{ Time Commitment } & \multirow[t]{2}{*}{47} & 13 & 18 & 11 & 5 & \multirow[t]{2}{*}{144} & 9 \\
\hline & & 27.7 & 38.3 & 23.4 & 10.6 & & \\
\hline Anxiety / Stress & 47 & 4 & 15 & 20 & 8 & 129 & 10 \\
\hline & & 8.5 & 31.9 & 42.6 & 17 & & \\
\hline Lack of Monetary & 47 & 6 & 10 & 12 & 19 & 109 & 11 \\
\hline Compensation & & 12.8 & 21.3 & 25.5 & 40.4 & & \\
\hline
\end{tabular}




\section{Connections to the Literature}

Many universities and school districts have joined to participate in K-12 education reform through the establishment of Professional Development School partnerships (PDS) (Castle et al., 2006). The mission of PDS states that PDS are committed to developing exemplary practices to maximize student outcomes, provide optimum sites for teacher preparation, offer research-based teacher professional development, and implement reflective inquiry to enhance learning for all (Cheng \& So, 2012; Latham \& Vogt, 2007; Pellett \& Pellett, 2009). In addition to these purposes, PDS serve as vehicles for simultaneous renewal of schooling and teacher preparation (Doolittle et al., 2008; Pratschler, 2009). In order to accomplish this educational agenda, PDS need ongoing opportunities to examine partnership goals and purpose (Leonard et al., 2004; Pratschler, 2009).

In support of clinical and field experiences, NCATE encourages the addition of more experiences especially those experiences that take place in professional development schools. Research from the National Association of Professional Development Schools (NAPDS), NCATE, and the American Association of Colleges for Teacher Education (AACTE), states that PDS improve both the quality of teaching and student learning, and by immersing candidates into classrooms with masterful teachers, and supporting the professional needs of both the candidate and the cooperating teachers. PDS are often compared to teaching hospitals, which are also hybrid institutions created in the early twentieth century (Castle et al., 2006; Cheng \& So, 2012; Darling-Hammond, 2005a, 2005b; Darling-Hammond et al., 2006; Pellett \& Pellett, 2009; "Transforming Teacher Education Through Clinical Practice: A National Strategy to Prepare Effective Teachers," 2011; Zionts et al., 2006). NCATE compares teaching and medicine because both are practicing professions and both require a sound academic program and intense clinical preparation ("Another Debate--the Quality of Teacher Preparation Programs," 2007; 
Darling-Hammond, 1999b; "Transforming Teacher Education Through Clinical Practice: A National Strategy to Prepare Effective Teachers," 2011). The teaching hospital was designed to provide such clinical preparation for medical students and interns; PDS serve the same function for teacher candidates and in-service faculty. Both settings provide support for professional learning in a real-world setting in which practice takes place (Brucklacher, 1998; Vaughn, 2012). The data collected does not show a major difference between PDS and NON-PDS schools, but the large majority of participants were teachers from PDS or partner schools. This fact suggests that teachers from PDS or partner schools may have felt a sense of obligation or desire to provide feedback to contribution to teacher preparation.

RQ3: Are the factors that affect the decision by practicing PK-12 teachers to accept placement of teacher candidates in clinical experiences significantly different based on selected teacher demographic?

After analyzing the data, it was determined demographic classification was not a significant factor in the decision making of teachers when considering mentoring teacher candidates. 


\section{CHAPTER FIVE: SUMMARY, DISCUSSION, AND RECOMMENDATIONS}

The purpose of this mixed methods study incorporating a web-based survey and focus group interviews was to obtain an understanding of practicing PK-12 teacher perceptions about clinical placements for teacher candidates. Particularly the factors that affect their decision to mentor teacher candidates in student teaching experiences. Realizing that clinical experience is hugely important to teacher preparation programs, PK-12 education, in-service and pre-service teacher, it is necessary to understand the perspective of the cooperating teachers. The teachers participating in the study taught in schools that are within the serving area of Moutaskis University's College of Education and Professional Development. The characteristics of teacher candidates have been examined widely among policy makers, teacher educators, and educational administrators. However, few studies have detailed the reasons that cooperating teachers may be willing or hesitant to mentor teacher candidates. Anecdotal evidence and logic suggest that the teachers who work with teacher candidates can add a new voice to the literature (Hogan, 2011). This study sought to explore how these perceptions affect decisions for mentoring teacher candidates and on what teachers base their feelings and decisions. Additionally, the researcher examined the linkage between Higher and PK-12 Education as it pertains to collaborating to meet the needs of teacher candidates and in-service educators.

Following a web-based questionnaire, practitioners were given the opportunity to participate in a focus group discussion to obtain more depth to the information gleaned from the survey. The focus group interview with the cooperating teachers who participated in this study would provide an opportunity for the teachers to express their particular perspectives on their experiences and reflect on their mentorship decisions.

Major themes emerged from the data analysis in response to the research questions. This final chapter contains an overview of the study, a summary of findings, implications, limitations, 
discussion, recommendations for future research, recommendations for practice, and conclusions. Findings from this study illuminated the teachers' perspective and their sense of what makes a positive, successful relationship between teacher education programs and public school districts. In many ways, the teachers' perceptions align with and support the suggested clinical model proposed by the NCATE report, in spite of those beliefs; several teachers shared their reluctance to mentor("Transforming Teacher Education Through Clinical Practice: A National Strategy to Prepare Effective Teachers," 2011). The findings also exposed the three is not a huge differences in the climate between a professional development school and a nonprofessional development school. In light of the release of the NCATE report, this study confirms and speaks to a number of points and strategies suggested for teacher education reform("Transforming Teacher Education Through Clinical Practice: A National Strategy to Prepare Effective Teachers," 2011).

\section{Summary}

Education in the 21 st century is encountering increased scrutiny, added pressure, and escalating external regulations, but the entities imposing this criticism do not offer practical and immediate solutions for improving teacher preparation programs. This criticism offers broadspectrum ideas, and professional experience seems to be a major focus of the transformation proposed (Badway \& Somerville, 2011). While legislation, accreditation bodies, and state departments of education calls for reformatory action through strengthened partnerships with local schools; the relationship between higher education and P-12 institutions often remains complicated and weak (Hess \& Darling Hammond, 2011; Spooner, Flowers, Lambert, \& Algozzine, 2008). For teacher preparation faculty working in clinical experiences with teacher candidates, the context continues to be very challenging. The fact remains that, professional experience is still considered essential to teacher preparation programs, and is unequivocally 
rated by teacher candidates as the most important component of their teacher preparation programs. In contrast, the command of practical and realistic concerns for higher education faculty involved with clinical experiences continue amongst the realities of the difficulty of securing quality placements, increased academic and teacher workloads, accountability and standards. Further, with the increased pressures on local public school administrators and teachers, the intent to meet state and national requirements for teacher preparation programs and to improve relationships with higher education proves cumbersome (Dee, 2012).

In response to the difficulty of finding clinical practice placements, and in an attempt to improve the clinical practice experience for candidates, the researcher surveyed in-service teachers to gain understanding of their perceptions about teacher candidate mentorship. The goal was to analyze how these perceptions influence clinical placements and how these perceptions may be changing the face of teacher preparation programs (National Council on Teacher, 2011). The participants, all certified teachers, all given the opportunity to mentor teacher candidates, and all were given the opportunity to participate in a focus group discussion. This study focused on cooperating teachers: their education and experience, school designation (PDS, partner, or Non-PDS), and their perception of mentorship. The factors that laid the foundation for this study included increased demands for teacher accountability, effective mentorship, teacher quality, and university requirements to develop professional training for cooperating teachers (NCATE 2010, National Research Consortium 2010, and NCTQ 2011 \& 2012).

Through the lens of educational legislation, the Elementary and Secondary Education Act (ESEA) in 1965 notably became the government's definitive entry into public education (Darling-Hammond et al., 2006). ESEA, in general, governs federal policy addressing K-12 education. Since its passage, ESEA has been reauthorized numerous times, including a major revision in 1994 following the re-release of the groundbreaking study, A Nation at Risk. In 2002 
ESEA was reborn as the No Child Left Behind Act (NCLB) this rebirth was a revision of ESEA

(Darling-Hammond, 2012c). Broadcasted as the most far-reaching bipartisan education

legislation ever passed by Congress, NCLB emphasized standardized assessments, local control of schools and funding tied to accountability (Darling-Hammond \& Berry, 2006; Selwyn, 2007; Smith, 2008).

Despite bipartisan political support, policy makers have been criticized for not having the pulse on educational needs; especially reform. Policy makers brought accountability to the forefront of education by emphasizing test taking. With the hopes that "high stakes testing" would serve as an effective accountability measure to make the United States more competitive internationally (Anselmo, 1997; Darling-Hammond, 2002, 2012d). Although these policies intended to create incentives for better teaching, most educators believe this piece of legislation has not only hurt students but also thwarted the art of teaching (Smith, 2008). Many educators believe that teaching to the test overshadows teaching critical thinking, higher-order reasoning, and the development of creative-writing skills. They also indicate that this pressure on test-topic time often causes a roadblock to clinical experience for teacher candidates. Even though education has continued to evolved, through the passage of (NCLB), and more recently the revision to NCLB, which offer, states the option to apply for an ESEA waiver. In both cases, accountability still falls in the laps of teachers and their administrators. With the demand for educational reform, the educational training facilities or universities, face the challenge of providing inclusive teacher preparation programs that offer comprehensive practicum experiences for teacher candidates and more training for cooperating teachers.

The research questions in this study were designed to explore issues concerning several aspects of teacher candidate mentorship from the perspective of the cooperating teacher. The research questions were as follows: 
1. What are the factors that affect the decision by practicing PK-12 teachers to accept placement of teacher candidates in clinical experiences?

2. Are the factors that affect the decision by practicing PK-12 teachers to accept placement of teacher candidates in clinical experiences significantly different based on the teacher's working at a school identified as a professional development school?

3. Are the factors that affect the decision by practicing PK-12 teachers to accept placement of teacher candidates in clinical experiences significantly different based on selected teacher demographic?

Data were collected from the questionnaire, and the focus group interview. Cooperating teachers participated in both the questionnaire and the focus group interview. The questionnaire informed the study about the factors that affect cooperating teachers' and their decision to mentor teacher candidates. Additionally, the researcher examined if there was a difference in the perceptions of cooperating teachers from PDS or Non-PDS schools, and if demographics played a role as well. The focus group interview provided opportunities to explore the research questions and encouraged cooperating teachers to reflect on their experiences. The analysis and coding of the data led to emergent themes that related to each supporting question under research question 1. The answers to these questions were coded, and three overarching themes emerged regarding research question 1. There were both positive and negative themes that reoccurred in the data collected. The positive themes that kept reoccurring in survey and the focus group were professional obligation/responsibility, contribution to the field, and sense of gate keeping those not ready to be teachers. Ninety-two percent of the teachers that participated in the survey reported that teacher candidate mentorship is a professional obligation. The open-ended portion of the questionnaire and the focus group illuminated the fact that while teachers believe they are obligated to mentor teacher candidates they struggle to balance that obligation with the imposed 
county, state, and student responsibilities. As stated in the open-ended responses, if something has to give it would be mentorship because my classroom responsibilities come first. Implications

\section{Higher Education}

Despite bipartisan support for the passage of NCLB, considerable criticism has been levied against it since its implementation (Guisbond, National Center for, \& Open, 2012). For several years, Congress has attempted to overhaul the legislation, yet there is little to show for its efforts. President Obama, however, made reauthorizing ESEA his top education priority. The administration released A Blueprint for Reform: The Reauthorization of the Elementary and Secondary Education Act in 2010. Proponents of accountability, NCTQ, Association of American Progress, and accreditation entities believe stiffer accountability criteria will exact change. Unfortunately, our current system for holding U.S. teacher preparation programs accountable does not guarantee program quality or serve the needs of schools and students, and even though accountability is important to educational reform, it is not integral to this research study (H. A. Johnson, 2013). Prior to the most recent educational policies, state oversight for teacher preparation programs mostly ignored the impact of graduates on the K-12 students they teach, and gave little attention to where graduates taught or how long they remained in the profession (Cochran-Smith \& Power, 2010; Crowe \& Center for American, 2010; G. T. Henry et al., 2012). There is no evidence that current state policies hold programs to high standards in order to produce teachers who can help students achieve. Moreover, every state does its own thing when it comes to program oversight-a barrier to effective quality control. Although, the higher education community is expected to respond to the reformed policies they have been at the periphery of conversations around K-12 education reform (Crowe \& Center for American, 
2010; National Council on Teacher, 2011). The higher education community is charged with developing and implementing preparation programs and professional development programs. CAEP calls for five major changes that will need to take place in teacher preparation and professional development programs (CAEP, 2012):

1. Increase selectivity and proactive recruitment to increase both the content knowledge of teachers and the diversity of the teaching force.

2. Alter the content of disciplinary courses for future and practicing teachers.

3. Alter the professional preparation courses for future and practicing teachers.

4. Identify, nurture, and sustain high quality field experiences for all future teachers.

5. Design and maintain a data collection system (including both assessments and infrastructure) committed to continuous improvement.

When considering professional preparation teacher preparation faculty are faced with several concerns to consider; and securing opportunities that best equip teachers with the necessary knowledge and skills may be the most difficult consideration. Research supports that clinical experience is essential to learning to teach; one cannot overlook the need to learn how to practice with real students in real classrooms (H. A. Johnson, 2013). Unfortunately, meaningful clinical experiences can be an uneven and unpredictable. It is particularly important that all teacher candidates be given opportunities to witness high quality instruction, and to learn alongside masterful teachers. One way that teacher preparation faculty is working toward this goal is to place students in environments that are supported by professional development.

As highlighted in this study, practicing teachers feel that teacher preparation programs are not giving prospective students what they need to be successful in the classroom. Several teachers stated that they feel disconnected with the curriculum taught in teacher preparation classes. Additionally, they feel that many times the application of theory is not practical in today's classroom. With school improvement in mind, teachers believe that they are using newer software, technology and instructional strategies (Act, 2012; Office of Postsecondary \& Westat, 
2011). Although teacher preparation faculty are sharpening their skills, classroom teachers still feel the lessons are not practical. In summation, teachers criticize teacher preparation programs for the following:

Not teaching curriculum that is relevant for today's classroom and students

$>$ Not implementing admissions requirements rigorous enough to attract highquality candidates

$>$ Not aligning programs requirements with expectations for student learning Not requiring/providing meaningful field experiences that lead into meaningful clinical experiences

Not creating an evaluation and accountability system to inform continuous program improvement (Allen \& Education Commission of the States, 2003)

Reviewing the reported criticisms, the common theme is disconnection, and even though teacher preparation programs are held to the state and national accreditation accountability standards, teachers have a different perspective.

\section{Implications for Public Schools}

The Clinical School Faculty member, historically referred to as the cooperating teacher, has emerged through the national redesign of teacher preparation programs as a key participant during clinical field experiences (Newton et al., 2012). While the face of PK-12 education continues to change, and teacher preparation programs answer the call for more and better clinical experiences. The cooperating teacher's role has not only gained importance but it has gained heightened responsibility as well. Although cooperating teachers have clearly definition of roles, qualifications, and responsibilities, they have rarely been questioned or researched. 
Clinical experience programs across the country have been criticized for their poor procedures for selecting school clinical faculty (Ronfeldt, 2012; "Turning Into Teachers: Influences of Authentic Context Learning Experiences on Occupational Identity Development of Preservice Music Teachers," 2011). More often than not, cooperating teachers are selected out of necessity, and many clinical directors admit that many placements have been more for convenience than for effectiveness (Huisman, 2007; O'Keefe et al., 2012). At times, the role of classroom assignments is delegated to the school principal. One study found that the most important criteria for selecting cooperating teachers was the recommendation of the principal, the evaluations completed by previous interns, and at least 3 years of teaching experience in the classroom (Dee, 2012; Gentry, 2008; Nichols, 1992; Spooner et al., 2008). However, the requirements of serving as a cooperating teacher continue to vary by state. The administrator remained the most important determinant of selecting cooperating teachers. Additionally, cooperating teachers selected were chosen more for their technical teaching skills and their willingness to mentor teacher candidates than for their professionalism and knowledge.

The teachers surveyed and researchers agree that high-quality practical experience is important in learning to teach, but the participants of this study have varying opinions of what high-quality experiences are. Some reported that simply providing the venue for the experience should be enough, and others view high-quality experiences to involve professional development, feedback, reflection, and analysis of student achievement data. It is clear from both the literature and our population that when done well, clinical experiences are invaluable. High quality clinical experiences ensure teacher candidates can apply the education program knowledge and skills they have acquired in the classroom. Like other parts of teacher preparation, the scope and duration of clinical and field experiences vary. For the clinical experience component, higher education faculty need to work with practitioners to decrease 
variability. Unfortunately, the comparison of high reliability organizations is not applicable to most classrooms or schools. Without communication, training, and memorandums of understanding between organizations variability will continue to mar the experiences of teacher candidates.

\section{Discussion}

After the completion of the qualitative data analysis, it was clear that there were critical themes that emerged from the open-ended questions and the focus groups. As the study revealed, the majority of practitioners surveyed are willing to host teacher candidates. This was a positive and unexpected finding, indicating that a previously held assumption, that few practicing teachers would be willing to turn over their classroom to a teacher candidate, should be questioned and further explored. Additional questions regarding placements, such as preparation, arose:

$>$ Do practitioners understand the roles and responsibilities of being a cooperating teacher?

$>$ Do school administrators view clinical experiences as learning experiences or a job interview?

$>$ Are practitioners equipped to remediate teacher candidates that need more support?

$>$ What are the expectations of practitioners for teacher candidates when it comes to student achievement?

$>$ Are generational differences a factor in decision making in school environments? How are cooperating teacher selected?

Other areas of research could focus on the triad, the relationship between the university supervisor, the cooperating teacher, and the teacher candidate. This relationship is fragile and 
can make or break the experience. While the research on teacher preparation is limited, this study does provide some guidance for both higher education and PK-12 education, including the value and impact of field and clinical experience for teacher preparation programs. Keeping in mind the relative narrowness of the research when weighing the participants' perceptions is helpful and gives perspective to others interested in furthering the work. Clearly, the issue of teacher preparation calls for more, and better, research. A number of recommendations are in order, but among the most important are the following (Allen \& Education Commission of the States, 2003; Darling-Hammond, 2000a, 2000b; Exstrom, 2009):

$>$ Make education research more responsive to the needs of policymakers and practitioners, and more accessible to all stakeholders

$>$ Strengthen research capacity by increasing overall investment and defining a strategic and coordinated research agenda

$>$ Ensure the research on teacher preparation defines more precisely the questions that need to be addressed and the data that need to be gathered

Make the connections to student achievement as explicit as possible

$>$ Create a culture in which all education stakeholders use solid research, and use it fairly, in making policy decisions.

Education researchers, policymakers, practitioners and funders all can play an important role in making the research on teacher preparation and education research, in general, more robust and significant. The goal should be nothing less than to make research as indispensable a feature of the decision-making process in education as it is in medicine and other evidence-based fields. The field needs a better understanding how to improve teacher preparation programs, communication between higher education and PK-12 educators and administrators, and fluidity 
CLINICAL PLACEMENT FACTORS 90

of theory and practice. This research, of the factors that influences teacher candidate placements as viewed by practicing teachers, though limited, provides a basis for future research concerning the acquisition of clinical placements and the expectations and requirements for teacher preparation programs with that of PK-12 schools. 


\section{REFERENCES}

Act, I. (2012). A First Look at Higher Performing High Schools: School Qualities that Educators Believe Contribute Most to College and Career Readiness: ACT, Inc.

Allen, M., \& Education Commission of the States, D. C. O. (2003). Eight Questions on Teacher Preparation: What Does the Research Say? A Summary of the Findings.

Anderson, D. (2007). THE ROLE OF COOPERATING TEACHERS' POWER IN STUDENT TEACHING. Education, 128(2), 307-323.

Another Debate--the Quality of Teacher Preparation Programs. (2007). Techniques: Connecting Education \& Careers, 82(1), 8-9.

Anselmo, A. (1997). Is There Life After Freshman Seminar? The Case for the Freshman Seminar Class Reunion. Journal of the Freshman Year Experience \& Students in Transition, 9(1), 105-130.

Applegate, J. H., \& Lasley, T. J. (1986). Early Field Experience: A Synthesis of RolePerspective Studies.

Badway, N. N., \& Somerville, J. (2011). Information Needs Perceived as Important by Leaders in Advanced Technological Education: Alignment with Community College Program Improvement Initiatives. Community College Journal of Research \& Practice, 35(1/2), 18-28. doi: 10.1080/10668926.2010.526047

Bird, L. K. (2012). Student Teacher Perceptions of the Impact of Mentoring on Student Teaching. (3511738 Ed.D.), Minnesota State University, Mankato, United States -Minnesota. Retrieved from http://ezproxy.Moutaskis.edu:2048/docview/1023446849?accountid=12281 ProQuest Dissertations \& Theses Full Text database.

Boyd, D., Goldhaber, D., Lankford, H., \& Wyckoff, J. (2007). The Effect of Certification and Preparation on Teacher Quality. Future of Children, 17(1), 45-68.

Brucklacher, B. (1998). Cooperating teachers' evaluations of student teachers: All. Journal of Instructional Psychology, 25(1), 67.

Carter, H., Amrein-Beardsley, A., \& Hansen, C. C. (2011). So NOT Amazing! Teach For America Corps Members' Evaluation of the First Semester of Their Teacher Preparation Program. Teachers College Record, 113(5), 861-894.

Castle, S., Fox, R. K., \& Souder, K. O. H. (2006). DO PROFESSIONAL DEVELOPMENT SCHOOLS (PDSs) MAKE A DIFFERENCE?: A COMPARATIVE STUDY OF PDS AND NON-PDS TEACHER CANDIDATES. Journal of Teacher Education, 57(1), 6580. doi: $10.1177 / 0022487105284211$ 
Cavanagh, M., \& Prescott, A. (2011). 10 good reasons to mentor a student teacher. Australian Mathematics Teacher, 67(2), 6-10.

Chaliès, S., Ria, L., Bertone, S., Trohel, J., \& Durand, M. (2004). Interactions between preservice and cooperating teachers and knowledge construction during post-lesson interviews. Teaching \& Teacher Education, 20(8), 765-781. doi:

10.1016/j.tate.2004.09.001

Chambers, G. N., Hobson, A. J., \& Tracey, L. (2010). 'Teaching could be a fantastic job but ...': three stories of student teacher withdrawal from initial teacher preparation programmes in England. Teachers \& Teaching, 16(1), 111-129. doi: 10.1080/13540600903475652

Cheng, M. M. H., \& So, W. W. M. (2012). Analysing teacher professional development through professional dialogue: an investigation into a university-school partnership project on enquiry learning. Journal of Education for Teaching, 38(3), 323-341. doi: $10.1080 / 02607476.2012 .668331$

Cochran-Smith, M., Cannady, M., McEachern, K. P., Mitchell, K., Piazza, P., Power, C., \& Ryan, A. (2012). Teachers' Education and Outcomes: Mapping the Research Terrain. Teachers College Record, 114(10), 1-49.

Cochran-Smith, M., \& Power, C. (2010). New Directions for Teacher Preparation. Educational Leadership, 67(8), 6-13.

Copeland, S. R., Keefe, E. B., Calhoon, A. J., Tanner, W., \& Park, S. (2011). Preparing Teachers to Provide Literacy Instruction to All Students: Faculty Experiences and Perceptions. Research \& Practice for Persons with Severe Disabilities, 36(3/4), 126-141.

Corte, M. V.-d., Brok, P. d., Kamp, M., \& Bergen, T. (2013). Teacher research in Dutch professional development schools: perceptions of the actual and preferred situation in terms of the context, process and outcomes of research. European Journal of Teacher Education, 36(1), 3-23. doi: 10.1080/02619768.2012.662639

Creswell, J. (2014). Research Design.

Crowe, E., \& Center for American, P. (2010). Measuring What Matters: A Stronger Accountability Model for Teacher Education: Online Submission.

Cuenca, A. (2011). The Role of Legitimacy in Student Teaching: Learning to "Feel" Like a Teacher. Teacher Education Quarterly, 38(2), 117-130.

Cuenca, A., Schmeichel, M., Butler, B. M., Dinkelman, T., \& Nichols, J. R. (2011). Creating a "third space" in student teaching: Implications for the university supervisor's status as outsider. Teaching \& Teacher Education, 27(7), 1068-1077. doi:

10.1016/j.tate.2011.05.003 
Darling-Hammond, L. (1996a). The quiet revolution rethinking teacher development. Educational Leadership, 53(6), 4.

Darling-Hammond, L. (1996b). What matters most. (Cover story). Phi Delta Kappan, 78(3), 193.

Darling-Hammond, L. (1999a). America's future: Educating teachers. Education Digest, 64(9), 18.

Darling-Hammond, L. (1999b). Educating Teachers. Academe, 85(1), 26.

Darling-Hammond, L. (2000a). Reforming Teacher Preparation and Licensing: Debating the Evidence. Teachers College Record, 102(1), 28.

Darling-Hammond, L. (2000b). Teaching for America's Future: National Commissions and Vested Interests in an Almost Profession. Educational Policy, 14(1), 162.

Darling-Hammond, L. (2002). What's at stake in high stakes testing? (Cover story). Brown University Child \& Adolescent Behavior Letter, 18(1), 1.

Darling-Hammond, L. (2005a). Prepping Our Teachers for Teaching as a Profession. Education Digest, 71(4), 22-27.

Darling-Hammond, L. (2005b). Teaching as a Profession: Lessons in Teacher Preparation and Professional Development. Phi Delta Kappan, 87(3), 237-240.

Darling-Hammond, L. (2006a). ASSESSING TEACHER EDUCATION THE USEFULNESS OF MULTIPLE MEASURES FOR ASSESSING PROGRAM OUTCOMES. Journal of Teacher Education, 57(2), 120-138. doi: 10.1177/0022487105283796

Darling-Hammond, L. (2006b). CONSTRUCTING 21st-CENTURY TEACHER EDUCATION. Journal of Teacher Education, 57(3), 300-314. doi: 10.1177/0022487105285962

Darling-Hammond, L. (2006c). No Child Left Behind and High School Reform. Harvard Educational Review, 76(4), 642-667.

Darling-Hammond, L. (2011a). Restoring Our Schools: THE QUEST FOR EQUITY IN THE UNITED STATES. Education Canada, 51(5), 14-18.

Darling-Hammond, L. (2011b). Teacher Preparation: Build on What Works. Education Week, $30(24), 36-26$.

Darling-Hammond, L. (2012a). REDLINING OUR SCHOOLS. Nation, 294(5), 11-15.

Darling-Hammond, L. (2012b). Should Student Test Scores Be Used to Evaluate Teachers?: No: Teaching Is Too Complex. Wall Street Journal - Eastern Edition, 259(147), R4-R4.

Darling-Hammond, L. (2012c). Soaring Systems. Education Review, 24(1), 24-33. 
Darling-Hammond, L. (2012d). The right start. Phi Delta Kappan, 94(3), 8-13.

Darling-Hammond, L., Amrein-Beardsley, A., Haertel, E., \& Rothstein, J. (2012). Evaluating teacher evaluation. Phi Delta Kappan, 93(6), 8-15.

Darling-Hammond, L., \& Berry, B. (2006). Highly Qualified Teachers for All. Educational Leadership, 64(3), 14-20.

Darling-Hammond, L., Dozer, C., Johnston, P., \& Rogers, R. (2006). TEACHER EDUCATION. Teachers College Record, 108(8), 1688-1694. doi: 10.1111/j.1467-9620.2006.00746.x

Dee, A. L. (2012). Collaborative Clinical Practice: An Alternative Field Experience. Issues in Teacher Education, 21(2), 147-163.

Denzin, N. K., \& Lincoln, Y. S. (2013). Collecting and interpreting qualitative materials (Fourth Edition. ed.). Thousand Oaks, California: SAGE Publications.

Doolittle, G., Sudeck, M., \& Rattigan, P. (2008). Creating Professional Learning Communities: The Work of Professional Development Schools. Theory Into Practice, 47(4), 303-310. doi: 10.1080/00405840802329276

Ediger, M. (2009). SUPERVISING THE STUDENT TEACHER IN THE PUBLIC SCHOOL. Education, 130(2), 251-254.

. Educational research; quantitative, qualitative, and mixed approaches, 4th ed. (2011) (Vol. 26): Book News, Inc.

Edwin, R. (2002). Mentoring Beginning Teachers: Findings from Contextual Supervision. Journal of Personnel Evaluation in Education, 16(3), 17.

Engaging our fears: student learning at the center of our practice. (2007). On the Horizon, 15(2), 99-106.

Enz, B. J., \& Cook, S. J. (1992). Student Teachers' and Cooperating Teachers' Perspectives of Mentoring Functions: Harmony or Dissonance?

Evans, C., Williams, J. B., King, L., \& Metcalf, D. (2010). Modeling, Guided Instruction, and Application of UDL in a Rural Special Education Teacher Preparation Program. Rural Special Education Quarterly, 29(4), 41-48.

Evans, L. (2010). Professionals or technicians? Teacher preparation programs and occupational understandings. Teachers \& Teaching, 16(2), 183-205. doi: $10.1080 / 13540600903478458$

Exstrom, M. (2009). What Teachers Need. State Legislatures, 35(8), 16-18.

Fantozzi, V. B. (2012). Making Meaning in Student Teaching. Action in Teacher Education, 34(2), 146-158. doi: 10.1080/01626620.2012.677738 
Floden, R. E. (2012). Teacher Value Added as a Measure of Program Quality: Interpret With Caution. Journal of Teacher Education, 63(5), 356-360. doi:

$10.1177 / 0022487112454175$

Gentry, R. (2008). Teacher Preparation beyond the Four Walls: What Clinical Experience does to Candidates: Online Submission.

Goodlad, J. I. (1990). Why Our Schools Don't Get Much Better--And How They Might. Teacher Education Quarterly, 17(4), 5-21.

Goodlad, J. I. (1993). School-University Partnerships and Partner Schools. Educational Policy, 7(1), 24-39.

Greenberg, J., McKee, A., Walsh, K., \& National Council on Teacher, Q. (2013). Teacher Prep Review: A Review of the Nation's Teacher Preparation Programs: National Council on Teacher Quality.

Guisbond, L., National Center for, F., \& Open, T. (2012). NCLB's Lost Decade for Educational Progress: What Can We Learn from this Policy Failure? : National Center for Fair \& Open Testing (FairTest).

Hall, K. M., Draper, R. J., Smith, L. K., \& Bullough, R. V., Jr. (2008). More than a Place to Teach: Exploring the Perceptions of the Roles and Responsibilities of Mentor Teachers. Mentoring \& Tutoring: Partnership in Learning, 16(3), 328-345.

Haskins, R., \& Loeb, S. (2007). A Plan to Improve the Quality of Teaching. Education Digest, 73(1), 51-56.

Henry, G. T., Kershaw, D. C., Zulli, R. A., \& Smith, A. A. (2012). Incorporating Teacher Effectiveness Into Teacher Preparation Program Evaluation. Journal of Teacher Education, 63(5), 335-355. doi: 10.1177/0022487112454437

Henry, J. J., Tryjankowski, A. M., DeCamillo, L., \& Bailey, N. (2010). How Professional Development Schools Can Help To Create Friendly Environments for Teachers To Integrate Theory, Research, and Practice. Childhood Education, 86(5), 327-331.

Hess, F. M., \& Darling Hammond, L. (2011). How to Rescue Education Reform. New York Times, 29.

Hobbs, S. F., \& Bullough Jr, R. V. (1998). Professional development schools: Catalysts for collaboration and change. Clearing House, 72(1), 47.

Hogan, A. S. B. (2011). Preservice teacher preparedness: Deficiencies and strengths. (3465883 Ph.D.), Capella University, United States -- Minnesota. Retrieved from http://ezproxy.Moutaskis.edu:2048/docview/884580511?accountid=12281 ProQuest Dissertations \& Theses Full Text database. 
Holmes, A., Polhemus, L., \& Jennings, S. (2005). CATIE: A Blended Approach to Situated Professional Development. Journal of Educational Computing Research, 32(4), 381-394.

Hoxie, J. (2010). Selected procedures and guidelines: A proposed K-6 student teaching model. (3397904 Ed.D.), Pepperdine University, United States -- California. Retrieved from http://ezproxy.Moutaskis.edu:2048/docview/193684713?accountid=12281 ProQuest Dissertations \& Theses Full Text database.

Huisman, S. E. (2007). Preservice teacher efficacy: The influence of field placements. (3269678 Ph.D.), University of Missouri - Saint Louis, United States -- Missouri. Retrieved from http://ezproxy.Moutaskis.edu:2048/docview/304762421?accountid=12281 ProQuest Dissertations \& Theses Full Text database.

Hunt, K. P. (2011). A comparison of selected supervisory skills of content specialist and noncontent specialist university supervisors. (3469138 Ph.D.), University of South Carolina, United States -- South Carolina. Retrieved from http://ezproxy.Moutaskis.edu:2048/docview/889959343?accountid=12281Retrieved from ProQuest Dissertations \& Theses Full Text database.

Johnson, H. A. (2013). Initial and Ongoing Teacher Preparation and Support: Current Problems and Possible Solutions. American Annals of the Deaf, 157(5), 439-449.

Johnson, P. J. (2011). K--6 Classroom Teachers' Perceptions of Effective Teacher Education Programs. (3493342 Ed.D.), East Tennessee State University, United States -Tennessee. Retrieved from http://ezproxy.Moutaskis.edu:2048/docview/918226618?accountid=12281 ProQuest Dissertations \& Theses Full Text database.

Kent, A. M. (2005). ACKNOWLEDGING THE NEED FACING TEACHER PREPARATION PROGRAMS: RESPONDING TO MAKE A DIFFERENCE. Education, 125(3), 343348.

Kent, S. I. (2001). Supervision of student teachers: practices of cooperating teachers prepared in a clinical supervision course. Journal of Curriculum \& Supervision, 16(3), 228.

Kim, M., \& Schallert, D. L. (2011). Building caring relationships between a teacher and students in a teacher preparation program word-by-word, moment-by-moment. Teaching \& Teacher Education, 27(7), 1059-1067. doi: 10.1016/j.tate.2011.05.002

Kim, T., \& Danforth, S. (2012). Non-authoritative approach to supervision of student teachers: cooperating teachers' conceptual metaphors. Journal of Education for Teaching, 38(1), 67-82. doi: 10.1080/02607476.2012.643658

Kirkpatrick, L., Lincoln, F., \& Morrow, L. R. (2006). Assessment of a Collaborative Teacher Preparation Program: Voices of Interns. Delta Kappa Gamma Bulletin, 73(1), 36-45. 
Koehnecke, D. S. (2001). PROFESSIONAL DEVELOPMENT SCHOOLS PROVIDE EFFECTIVE THEORY AND PRACTICE. Education, 121(3), 589.

Koster, B., Korthagen, F. A. J., \& Wubbels, T. (1998). Is There Anything Left for Us? Functions of cooperating teachers and teacher educators. European Journal of Teacher Education, $21(1), 75$.

Larson, A. (2005). Preservice Teachers' Field Experience Surprises: Some Things Never Change. Physical Educator, 62(3), 154-163.

Latham, N. I., \& Vogt, W. P. (2007). DO PROFESSIONAL DEVELOPMENT SCHOOLS REDUCE TEACHER ATTRITION? Journal of Teacher Education, 58(2), 153-167.

Le Cornu, R., \& Ewing, R. (2008). Reconceptualising Professional Experiences in Pre-Service Teacher Education...Reconstructing the Past to Embrace the Future. Teaching and Teacher Education: An International Journal of Research and Studies, 24(7), 1799-1812.

Ledoux, M. W., \& McHenry, N. (2008). Pitfalls of School-University Partnerships. Clearing House, 81(4), 155-160.

Leonard, J., Lovelace-Taylor, K., Sanford-Deshields, J., \& Spearman, P. (2004). PROFESSIONAL DEVELOPMENT SCHOOLS REVISITED Reform, Authentic Partnerships, and New Visions. Urban Education, 39(5), 561-583. doi: $10.1177 / 0042085904266968$

Lowing, K. (2011). Educational Research and Inquiry: Qualitative and Quantitative Approaches. Edited by D. Hartas: Pp 458. London: Continuum. 2010. $£ 34.99$ (pbk). ISBN 9781441178718. British Journal of Educational Studies, 59(3), 350-351. doi: 10.1080/00071005.2011.611285

Lu, H.-L. (2007). Mentor teachers, program supervisors, and peer coaching in the student teaching experience: A phenomenological study of the experiences of mentor teachers, program supervisors, and interns. (3289285 Ed.D.), University of Massachusetts Amherst, United States -- Massachusetts. Retrieved from http://ezproxy.Moutaskis.edu:2048/docview/304846374?accountid=12281 ProQuest Dissertations \& Theses Full Text database.

Maltas, C. J., \& McCarty-Clair, J. (2006). Once a Student, Now a Mentor: Preparing to Be a Cooperating Teacher. Music Educators Journal, 93(2), 48-52.

McCann, T. M. (2012). Mentoring Matters. English Journal, 102(1), 84-87.

Melody, L. R., \& Jared, A. R. (2011). Mentoring Relationships: Cooperating Teachers' Perspectives on Mentoring Student Interns. The Professional Educator, 35(1), 1.

Mentoring pre-service teachers: A case study, 35, a2h 14-20, Australasian Journal of Early Childhood (Early Childhood Australia 2010). 
Merriam-Webster. (2014). Merriam-Webster's Collegiate Dictionary.

Moehle, M. R. (2011). A mixed methods study exploring strengths-based mentoring in clinical practice and student teacher development. (3450107 Ph.D.), The University of Nebraska - Lincoln, United States -- Nebraska. Retrieved from http://ezproxy.Moutaskis.edu:2048/docview/864032698?accountid=12281 ProQuest Dissertations \& Theses Full Text database.

Montecinos, C., Walker, H., Rittershaussen, S., Nuñez, C., Contreras, I., \& Solís, M. C. (2011). Defining content for field-based coursework: Contrasting the perspectives of secondary preservice teachers and their teacher preparation curricula. Teaching \& Teacher Education, 27(2), 278-288. doi: 10.1016/j.tate.2010.09.001

National Council on Teacher, Q. (2011). Removing the Roadblocks: How Federal Policy Can Cultivate Effective Teachers. Recommendations for the Reauthorization of the Elementary and Secondary Education Act: National Council on Teacher Quality.

Newton, J. M., Jolly, B. C., Ockerby, C. M., \& Cross, W. M. (2012). Student centredness in clinical learning: the influence of the clinical teacher. Journal of Advanced Nursing, 68(10), 2331-2340. doi: 10.1111/j.1365-2648.2012.05946.x

Nguyen, H. T. (2009). An inquiry-based practicum model: What knowledge, practices, and relationships typify empowering teaching and learning experiences for student teachers, cooperating teachers and college supervisors? Teaching \& Teacher Education, 25(5), 655-662. doi: 10.1016/j.tate.2008.10.001

Nichols, T. M. (1992). Clinical Experiences in Teacher Preparation Programs: A Scope and Sequence Model.

Nilssen, V. L. (2010). Guided Planning in First-Year Student Teachers' Teaching. Scandinavian Journal of Educational Research, 54(5), 431-449. doi: 10.1080/00313831.2010.508909

Nolan, B., \& Palazzolo, L. (2011). New Teacher Perceptions of the "Teacher Leader" Movement. NASSP Bulletin, 95(4), 302-318.

O'Keefe, M., Burgess, T., McAllister, S., \& Stupans, I. (2012). Twelve tips for supporting student learning in multidisciplinary clinical placements. Medical Teacher, 34(11), 883887. doi: 10.3109/0142159X.2012.700431

Office of Postsecondary, E., \& Westat, I. (2011). Preparing and Credentialing the Nation's Teachers: The Secretary's Eighth Report on Teacher Quality Based on Data Provided for 2008, 2009 and 2010: Office of Postsecondary Education, US Department of Education.

Pellett, H. H., \& Pellett, T. (2009). Professional Development Schools: A Model for Effective P16 Physical Education Partnerships. JOPERD: The Journal of Physical Education, Recreation \& Dance, 80(1), 31-38. 
Petrilli, M. J., Finn, C. E., Jr., \& Thomas, B. F. I. (2011). ESEA Briefing Book: Thomas B. Fordham Institute.

Pratschler, M. (2009). Effects of mentoring preservice teachers on inservice teachers in professional development school environments. (3369791 Ed.D.), Walden University, United States -- Minnesota. Retrieved from http://ezproxy.Moutaskis.edu:2048/docview/305078062?accountid=12281 ProQuest Dissertations \& Theses Full Text database.

Preparing Teachers: Building Evidence for Sound Policy. (2010). National Academies Press.

Rajuan, M., Beijaard, D., \& Verloop, N. (2007). The role of the cooperating teacher: bridging the gap between the expectations of cooperating teachers and student teachers. Mentoring \& Tutoring: Partnership in Learning, 15(3), 223-242. doi: 10.1080/13611260701201703

Rajuan, M., Beijaard, D., \& Verloop, N. (2010). The match and mismatch between expectations of student teachers and cooperating teachers: exploring different opportunities for learning to teach in the mentor relationship. Research Papers in Education, 25(2), 201223. doi: 10.1080/02671520802578402

Rieg, S. A., Paquette, K. R., \& Chen, Y. (2007). Coping with stress:an investigation of novice teachers' stressors in the elementary classroom. Education, 128(2), 211-226.

Riggsbee, J., Malone, D., \& Straus, M. (2012). The Role of Liberal Education in Preparing Tomorrow's Teachers. Peer Review, 14(2), 12-15.

Ronfeldt, M. (2012). Where Should Student Teachers Learn to Teach? Effects of Field Placement School Characteristics on Teacher Retention and Effectiveness. Educational Evaluation and Policy Analysis, 34(1), 3-26.

Ronfeldt, M., \& Reininger, M. (2012). More or Better Student Teaching? Teaching and Teacher Education: An International Journal of Research and Studies, 28(8), 1091-1106.

Rozelle, J. J., \& Wilson, S. M. (2012). Opening the black box of field experiences: How cooperating teachers' beliefs and practices shape student teachers' beliefs and practices. Teaching \& Teacher Education, 28(8), 1196-1205. doi: 10.1016/j.tate.2012.07.008

Russell, M. L., \& Russell, J. A. (2011). Mentoring Relationships: Cooperating Teachers' Perspectives on Mentoring Student Interns. Professional Educator, 35(1).

Russell-McKenzie, E. J. (2009). Evaluating student teaching experiences at urban and suburban field sites: Relationship to teacher efficacy, preparedness, and commitment. (3359702 Ph.D.), Temple University, United States -- Pennsylvania. Retrieved from http://ezproxy.Moutaskis.edu:2048/docview/305016746? accountid=12281Retrieved from ProQuest Dissertations \& Theses Full Text database. 
Sawchuk, S. (2011a). NCTQ Review Sharply Critical Of Student-Teacher Programs. Education Week, 30(37), 4-4.

Sawchuk, S. (2011b). NCTQ, U.S. News Launch Teacher Education Review. Education Week, 30(18), 4-4.

Scheeler, M. C. (2008). Generalizing Effective Teaching Skills: The Missing Link in Teacher Preparation. Journal of Behavioral Education, 17(2), 145-159. doi: 10.1007/s10864-0079051-0

Scherer, M. (2012). The Challenges of Supporting New Teachers (Vol. 69, pp. 18-23): Association for Supervision \& Curriculum Development.

Selwyn, D. (2007). HIGHLY QUANTIFIED TEACHERS. Journal of Teacher Education, 58(2), 124-137.

Sherman, N. W. (2001). A Study of Cooperating Teachers. JOPERD: The Journal of Physical Education, Recreation \& Dance, 72(2), 8.

Siebert, C. J., Clark, A., Kilbridge, A., \& Peterson, H. (2006). WHEN PRESERVICE TEACHERS STRUGGLE OR FAIL: MENTOR TEACHERS' PERSPECTIVES. Education, 126(3), 409-422.

Sikes, P. J., Nixon, J., Carr, W., \& ebrary, I. (2003). The moral foundations of educational research: knowledge, inquiry, and values. Maidenhead U6 - ctx_ver=Z39.882004\&ctx_enc=info:ofi/enc:UTF8\&rfr_id=info:sid/summon.serialssolutions.com\&rft_val_fmt=info:ofi/fmt:kev:mtx:book $\&$ rft.genre=book\&rft.title $=$ The + moral + foundations + of + educational+research $\& r f t . a u=S i k$ es,+Patricia+J\&rft.au=Nixon,+Jon\&rft.au=Carr,+Wilfred\&rft.date=2003-0101\&rft.pub=Open+University+Press\&rft.externalDocID=b14169691 U7 - eBook U8 FETCH-Moutaskis_catalog_b141696911: Open University Press.

Sim, C. (2011). 'You've either got [it] or you haven't' - conflicted supervision of preservice teachers. Asia-Pacific Journal of Teacher Education, 39(2), 139-149. doi: 10.1080/1359866X.2011.560653

Sinclair, C., Dowson, M., \& Thistleton-Martin, J. (2006). Motivations and profiles of cooperating teachers: Who volunteers and why? Teaching \& Teacher Education, 22(3), 263-279. doi: 10.1016/j.tate.2005.11.008

Siwatu, K. O. (2011). Preservice teachers' sense of preparedness and self-efficacy to teach in America's urban and suburban schools: Does context matter? Teaching \& Teacher Education, 27(2), 357-365. doi: 10.1016/j.tate.2010.09.004

Smith, E. (2008). Raising standards in American schools? Problems with improving teacher quality. Teaching \& Teacher Education, 24(3), 610-622. doi: 10.1016/j.tate.2007.09.013 
Spooner, M., Flowers, C., Lambert, R., \& Algozzine, B. (2008). Is More Really Better? Examining Perceived Benefits of an Extended Student Teaching Experience. Clearing House, 81(6), 263-270.

Steinberg, A., \& Harvard Univ, C. M. A. G. S. o. E. (1992). The "Best" of the Harvard Education Letter: Harvard Education Letter.

Talvitie, U., Peltokallio, L., \& Mannisto, P. (2000). Student Teachers' Views about their Relationships with University Supervisors, Cooperating Teachers and Peer Student Teachers. Scandinavian Journal of Educational Research, 44(1), 79-88. doi: 10.1080/003138300114493

THE COOPERATING TEACHER AND HUMAN RELATIONS. (1971). Education, 92(2), 99. Transforming Teacher Education through Clinical Practice: A National Strategy to Prepare Effective Teachers. (2011). Education Digest: Essential Readings Condensed for Quick Review, 76(7), 9-13.

. Transforming Teacher Education Through Clinical Practice: A National Strategy to Prepare Effective Teachers. (2011) (Vol. 76, pp. 9-13): Prakken Publications.

Trautwein, B., \& Ammerman, S. (2010). From Pedagogy to Practice: Mentoring and Reciprocal Peer Coaching for Preservice Teachers. Volta Review, 110(2), 191-206.

Turning Into Teachers: Influences of Authentic Context Learning Experiences on Occupational Identity Development of Preservice Music Teachers, 59, aph 369-392, Journal of Research in Music Education (Sage Publications Inc. 2011).

Vaughn, K. A. (2012). Teacher Dispositions and Student Achievement. (3505422 Ph.D.), The Claremont Graduate University, United States -- California. Retrieved from http://ezproxy.Moutaskis.edu:2048/docview/1013442390?accountid=12281 ProQuest Dissertations \& Theses Full Text database.

Veltri, B. T. (2012). Teach for America: It's More About Leading Than Teaching. Educational Leadership, 69(8), 62-65.

Voltz, D. L., \& Fore, C. (2006). Urban Special Education in the Context of Standards-Based Reform. Remedial and Special Education, 27(6), 329-336.

Walkington, J. (2007). Improving Partnerships between Schools and Universities: Professional Learning with Benefits beyond Preservice Teacher Education. Teacher Development, 11(3), 277-294.

Washburn, E. K., Matesha Joshi, R., \& Binks Cantrell, E. (2011). Are preservice teachers prepared to teach struggling readers? Annals of Dyslexia, 61(1), 21-43. doi: 10.1007/s11881-010-0040-y 
Weimer, K. R. (2011). A survey of mentoring programs for novice K-12 teachers in West Virginia public schools. Visions of research in music education, 18, 14.

Woods, A. M., \& Weasmer, J. (2003). GREAT EXPECTATIONS FOR STUDENT TEACHERS: EXPLICIT AND IMPLIED. Education, 123(4), 681.

Zionts, L. T., Shellady, S. M., \& Zionts, P. (2006). Teachers' Perceptions of Professional Standards: Their Importance and Ease of Implementation. Preventing School Failure, $50(3), 5-12$. 


\section{TABLES}

TABLE 1 Demographics of Population

\section{Number}

Gender

Female

195

Male

44

Race

American-Indian or 1

Native Alaskan

Asian 2

African American or 2

Black

White

\section{Percent}

82

18

0.4

1

1

86

Ethnicity

Hispanic or Latino 2

Non-Hispanic or Latino 186

Age Range

$\begin{array}{lll}25-30 & 30 & 13 \\ 31-35 & 31 & 13 \\ 36-40 & 24 & 10 \\ 41-45 & 24 & 10 \\ 46-50 & 37 & 15 \\ 51-55 & 35 & 15 \\ 56+ & 27 & 11\end{array}$

Level of Education

$\begin{array}{lll}\text { BA/BS } & 11 & 4 \\ \text { BA/BS +15 } & 59 & 25 \\ \text { MA/MS } & 13 & 5 \\ \text { MA/MS +15 } & 27 & 11 \\ \text { MA/MS +30 } & 24 & 10 \\ \text { MA/MS +45 } & 76 & 32 \\ \text { Ed.Ms. } & 3 & 1\end{array}$


Grade Level Taught

$\begin{array}{lll}\text { Pre-school } & 1 & 1 \\ \text { Elementary School } & 93 & 47 \\ \text { Middle School } & 45 & 23 \\ \text { High School } & 61 & 31 \\ \text { Teaching Experience } & & \\ 0 & 35 & 15 \\ 1-3 & 16 & 7 \\ 4-6 & 30 & 13 \\ 7-10 & 44 & 18 \\ 11-15 & 27 & 11 \\ 16-20 & 23 & 10 \\ 21-30 & 42 & 17 \\ 30+ & 22 & 9\end{array}$


TABLE 2: Ranked influential factors

Influential Factors

\begin{tabular}{|c|c|c|c|c|c|c|c|}
\hline & $\mathrm{N}$ & $\begin{array}{l}\text { Very } \\
\text { important }\end{array}$ & $\begin{array}{l}\text { Somewhat } \\
\text { important }\end{array}$ & $\begin{array}{l}\text { Not very } \\
\text { important }\end{array}$ & $\begin{array}{l}\text { Not } \\
\text { influential }\end{array}$ & $\begin{array}{l}\text { Weighted } \\
\text { Score }\end{array}$ & Rank \\
\hline \multirow{2}{*}{$\begin{array}{l}\text { Commitment to Improving the } \\
\text { Field of Education }\end{array}$} & 173 & 125 & 39 & 6 & 3 & 638 & 1 \\
\hline & & 72.2 & 22.5 & 3.5 & 1.7 & & \\
\hline \multirow{2}{*}{$\begin{array}{l}\text { Contribution to teacher } \\
\text { preparation }\end{array}$} & 173 & 110 & 55 & 8 & 0 & 629 & 2 \\
\hline & & 63.6 & 31.8 & 4.6 & 0.0 & & \\
\hline \multirow{2}{*}{$\begin{array}{l}\text { Involvement in teacher } \\
\text { candidate preparation }\end{array}$} & 173 & 101 & 58 & 12 & 2 & 616 & 3 \\
\hline & & 58.3 & 33.5 & 6.9 & 1.1 & & \\
\hline \multirow{2}{*}{$\begin{array}{l}\text { Teacher Candidate exhibits } \\
\text { professionalism }\end{array}$} & 173 & 97 & 68 & 7 & 1 & 614 & 4 \\
\hline & & 56.0 & 39.3 & 4.0 & 0.6 & & \\
\hline \multirow[t]{2}{*}{ Professional Obligation } & 173 & 94 & 52 & 15 & 12 & 589 & 5 \\
\hline & & 54.3 & 30.0 & 8.6 & 6.9 & & \\
\hline \multirow{2}{*}{$\begin{array}{l}\text { Candidate prepared with } \\
\text { content knowledge }\end{array}$} & 173 & 79 & 72 & 16 & 6 & 586 & 6 \\
\hline & & 45.7 & 41.6 & 9.2 & 3.5 & & \\
\hline \multirow{2}{*}{$\begin{array}{l}\text { Opportunity to sharpen } \\
\text { professional skills }\end{array}$} & 173 & 85 & 61 & 18 & 9 & 586 & 7 \\
\hline & & 49.1 & 35.2 & 10.4 & 5.2 & & \\
\hline \multirow{2}{*}{$\begin{array}{l}\text { Candidate prepared to plan } \\
\text { and deliver lessons }\end{array}$} & 171 & 72 & 83 & 14 & 2 & 581 & 8 \\
\hline & & 42.1 & 48.5 & 8.1 & 1.1 & & \\
\hline \multirow[t]{2}{*}{ Time Commitment } & 172 & 54 & 61 & 41 & 16 & 538 & 9 \\
\hline & & 31.4 & 35.4 & 23.8 & 9.2 & & \\
\hline \multirow[t]{2}{*}{ Anxiety/Stress } & 173 & 23 & 59 & 60 & 31 & 480 & 10 \\
\hline & & 13.3 & 34.1 & 34.7 & 17.9 & & \\
\hline \multirow[t]{2}{*}{ Monetary compensation } & 173 & 17 & 37 & 50 & 69 & 389 & 11 \\
\hline & & 9.8 & 21.4 & 28.9 & 39.9 & & \\
\hline
\end{tabular}




\begin{tabular}{|c|c|c|c|c|c|c|c|}
\hline & $\mathrm{N}$ & $\begin{array}{l}\text { Very } \\
\text { important }\end{array}$ & $\begin{array}{l}\text { Somewhat } \\
\text { important }\end{array}$ & $\begin{array}{l}\text { Not very } \\
\text { important }\end{array}$ & $\begin{array}{l}\text { Not } \\
\text { influential }\end{array}$ & $\begin{array}{l}\text { Weighted } \\
\text { Score }\end{array}$ & Rank \\
\hline \multirow{2}{*}{$\begin{array}{l}\text { Commitment to Improving } \\
\text { the field }\end{array}$} & \multirow[t]{2}{*}{47} & 40 & 6 & 1 & 0 & \multirow[t]{2}{*}{181} & \multirow[t]{2}{*}{1} \\
\hline & & 85.1 & 12.8 & 2.1 & 0 & & \\
\hline \multirow{2}{*}{$\begin{array}{l}\text { Contribution to Teacher } \\
\text { Preparation }\end{array}$} & \multirow[t]{2}{*}{47} & 34 & 12 & 1 & 0 & \multirow[t]{2}{*}{175} & \multirow[t]{2}{*}{2} \\
\hline & & 72.3 & 25.5 & 2.1 & 0 & & \\
\hline \multirow{2}{*}{$\begin{array}{l}\text { Involvement to Teacher } \\
\text { Preparation }\end{array}$} & 47 & 32 & 13 & 1 & 1 & \multirow[t]{2}{*}{171} & \multirow[t]{2}{*}{3} \\
\hline & & 68.1 & 27.7 & 2.1 & 2.1 & & \\
\hline \multirow{2}{*}{$\begin{array}{l}\text { Teacher Candidate } \\
\text { Professionalism }\end{array}$} & \multirow[t]{2}{*}{47} & 28 & 18 & 1 & 0 & \multirow[t]{2}{*}{169} & \multirow[t]{2}{*}{4} \\
\hline & & 59.6 & 38.3 & 2.1 & 0 & & \\
\hline \multirow[t]{2}{*}{ Professional obligation } & \multirow[t]{2}{*}{47} & 28 & 14 & 3 & 2 & \multirow[t]{2}{*}{165} & \multirow[t]{2}{*}{5} \\
\hline & & 59.6 & 29.8 & 6.4 & 4.26 & & \\
\hline \multirow{2}{*}{$\begin{array}{l}\text { Teacher Candidate content } \\
\text { knowledge preparation }\end{array}$} & \multirow[t]{2}{*}{47} & 21 & 21 & 2 & 3 & \multirow[t]{2}{*}{156} & \multirow[t]{2}{*}{6} \\
\hline & & 44.7 & 44.7 & 4.26 & 6.4 & & \\
\hline \multirow{2}{*}{$\begin{array}{l}\text { Effective instructional } \\
\text { delivery }\end{array}$} & \multirow[t]{2}{*}{47} & 15 & 30 & 2 & 0 & \multirow[t]{2}{*}{156} & \multirow[t]{2}{*}{7} \\
\hline & & 31.9 & 63.8 & 4.26 & 0 & & \\
\hline \multirow{2}{*}{$\begin{array}{l}\text { Opportunity to sharpen } \\
\text { skills }\end{array}$} & \multirow[t]{2}{*}{47} & 22 & 18 & 4 & 2 & \multirow[t]{2}{*}{156} & \multirow[t]{2}{*}{8} \\
\hline & & 46.8 & 38.3 & 8.5 & 4.26 & & \\
\hline \multirow[t]{2}{*}{ Time Commitment } & \multirow[t]{2}{*}{47} & 13 & 18 & 11 & 5 & \multirow[t]{2}{*}{144} & 9 \\
\hline & & 27.7 & 38.3 & 23.4 & 10.6 & & \\
\hline Anxiety / Stress & 47 & 4 & 15 & 20 & 8 & 129 & 10 \\
\hline & & 8.5 & 31.9 & 42.6 & 17 & & \\
\hline Lack of Monetary & 47 & 6 & 10 & 12 & 19 & 109 & 11 \\
\hline Compensation & & 12.8 & 21.3 & 25.5 & 40.4 & & \\
\hline
\end{tabular}


TABLE 4 Influential Factors as ranked by teachers from school that are not PDSs

\begin{tabular}{|c|c|c|c|c|c|c|c|}
\hline & $\mathrm{N}$ & $\begin{array}{l}\text { Very } \\
\text { important }\end{array}$ & $\begin{array}{l}\text { Somewhat } \\
\text { important }\end{array}$ & $\begin{array}{l}\text { Not very } \\
\text { important }\end{array}$ & $\begin{array}{l}\text { Not } \\
\text { influential }\end{array}$ & $\begin{array}{l}\text { Weighted } \\
\text { Score }\end{array}$ & Rank \\
\hline \multirow{2}{*}{$\begin{array}{l}\text { Contribution to Teacher } \\
\text { Preparation }\end{array}$} & \multirow[t]{2}{*}{6} & 6 & 0 & 0 & 0 & \multirow[t]{2}{*}{24} & \multirow[t]{2}{*}{1} \\
\hline & & 100 & 0 & 0 & 0 & & \\
\hline \multirow{2}{*}{$\begin{array}{l}\text { Involvement to Teacher } \\
\text { Preparation }\end{array}$} & \multirow[t]{2}{*}{6} & 6 & 0 & 0 & 0 & \multirow[t]{2}{*}{24} & \multirow[t]{2}{*}{1} \\
\hline & & 100 & 0 & 0 & 0 & & \\
\hline \multirow{2}{*}{$\begin{array}{l}\text { Commitment to Improving the } \\
\text { field }\end{array}$} & 6 & 6 & 0 & 0 & 0 & \multirow[t]{2}{*}{24} & \multirow[t]{2}{*}{1} \\
\hline & & 100 & 0 & 0 & 0 & & \\
\hline \multirow[t]{2}{*}{ Professional obligation } & 6 & 5 & 1 & 0 & 0 & \multirow[t]{2}{*}{23} & \multirow[t]{2}{*}{2} \\
\hline & & 83.4 & 16.7 & 0 & 0 & & \\
\hline \multirow{2}{*}{$\begin{array}{l}\text { Teacher Candidate } \\
\text { Professionalism }\end{array}$} & 6 & 5 & 1 & 0 & 0 & \multirow[t]{2}{*}{23} & \multirow[t]{2}{*}{2} \\
\hline & & 83.3 & 16.7 & 0 & 0 & & \\
\hline \multirow[t]{2}{*}{ Opportunity to sharpen skills } & 6 & 5 & 1 & 0 & 0 & \multirow[t]{2}{*}{21} & \multirow[t]{2}{*}{2} \\
\hline & & 83.3 & 16.7 & 0 & 0 & & \\
\hline \multirow{2}{*}{$\begin{array}{l}\text { Effective instructional } \\
\text { delivery }\end{array}$} & 6 & 3 & 3 & 0 & 0 & \multirow[t]{2}{*}{21} & \multirow[t]{2}{*}{3} \\
\hline & & 50 & 50 & 0 & 0 & & \\
\hline \multirow[t]{2}{*}{ Time Commitment } & 6 & 2 & 2 & 2 & 0 & \multirow[t]{2}{*}{20} & \multirow[t]{2}{*}{4} \\
\hline & & 33.3 & 33.3 & 33.3 & 0 & & \\
\hline \multirow{2}{*}{$\begin{array}{l}\text { Teacher Candidate content } \\
\text { knowledge preparation }\end{array}$} & 6 & 2 & 3 & 1 & 0 & \multirow[t]{2}{*}{20} & \multirow[t]{2}{*}{4} \\
\hline & & 33.3 & 50 & 16.7 & 0 & & \\
\hline \multirow[t]{2}{*}{ Anxiety / Stress } & 6 & 0 & 2 & 4 & 0 & \multirow[t]{2}{*}{18} & \multirow[t]{2}{*}{5} \\
\hline & & 0 & 33.3 & 66.7 & 0 & & \\
\hline \multirow{2}{*}{$\begin{array}{l}\text { Lack of Monetary } \\
\text { Compensation }\end{array}$} & 6 & 2 & 0 & 3 & 1 & \multirow[t]{2}{*}{18} & 5 \\
\hline & & 33.3 & 0.0 & 50.0 & 16.7 & & \\
\hline
\end{tabular}




\section{APPENDICES}

Dear Participant,

This letter is a request for you to take part in a research project to identify the factors that influence teachers' decision to mentor teacher candidates. This project is being conducted by Kristi James, in the Office of Clinical Experiences and Professional Development Schools in the College of Education at Moutaskis University. Your participation in this project is greatly appreciated. It will take approximately 15 minutes to fill out the attached questionnaire.

Your involvement in this project will be kept as confidential as legally possible. All data will be reported in the aggregate form. You must be 18 years of age or older to participate. I will not ask any information that should lead back to your identity as a participant. Your participation is voluntary. You may skip any question that you do not wish to answer and you may discontinue at any time. West Virginia University's Institutional Review Board acknowledgement of this project is on file.

I hope that you will participate in this research project, as it could be beneficial in understanding the impact of grades on student life. Thank you very much for your time. Should you have any questions about this letter or the research project, please contact Dr. Adriane Williams or me. Dr. Williams is supervising this study. Dr. Williams can be contacted via email at adriane.a.williams@gmail.com or by phone at (901) 249-7259, and I can be contacted at (304) 696-3100 or by e-mail at Kristi.james@ Moutaskis.edu .

Thank you for your time and help with this project.

Sincerely,

Kristi James

Chestnut Ridge Research Building

Phone: 304-293-7073 886 Chestnut Ridge Road

Fax: 304-293-3098 PO Box 6845

http://oric.research.wvu.edu Morgantown, WV 26506-6845 


\section{B. Questionnaire}

Factors that influence classroom teachers to mentor teacher candidates

Q1 Please take a few minutes to answer the following questions. Your feedback will provide valuable data for Moutaskis University to reflect on and make appropriate revisions to our Teacher Preparation Program and the operations of the Office of Clinical Experience. Please be candid - we need your open and honest opinion. Data are confidential and anonymous. Only aggregate data are provided to the individual education programs. Thank you for your time in completing this survey and your dedication in helping us prepare excellent future teachers. Sincerely,

Kristi James 


\section{Q2 What is your gender?}

Male (1)

Female (2)

\section{Q3 What is your age range?}

25-30 (1)

$31-35(2)$

$36-40(3)$

$41-45(4)$

$46-50(5)$

$51-55(6)$

$56+(7)$

\section{Q4 What is your racial background? (Check one)}

American Indian or Alaska Native: A person having origins in any of the original peoples of North and South America (including Central America), and who maintains tribal affiliation or community attachment. (1)

Asian: A person having origins in any of the original peoples of the Far East, Southeast Asia, or the Indian subcontinent, including, for example, Cambodia, China, India, Japan, Korea, Malaysia, Pakistan, the Philippine Islands, Thailand, and Vietnam. (2)

Black or African American: A person having origins in any of the black racial groups of Africa or the Caribbean (3)

Native Hawaiian or Other Pacific Islander: A person having origins in any of the original peoples of Hawaii, Guam, Samoa, or other Pacific Islands (4)

White: A person having origins in any of the original peoples of Europe, the Middle East, or North Africa (5)

\section{Q5 What is your racial background? (Check all that apply)}

American Indian or Alaska Native: A person having origins in any of the original peoples of North and South America (including Central America), and who maintains tribal affiliation or community attachment. (1) 
Asian: A person having origins in any of the original peoples of the Far East, Southeast Asia, or the Indian subcontinent, including, for example, Cambodia, China, India, Japan, Korea, Malaysia, Pakistan, the Philippine Islands, Thailand, and Vietnam. (2)

Black or African American: A person having origins in any of the black racial groups of Africa or the Caribbean (3)

Native Hawaiian or Other Pacific Islander: A person having origins in any of the original peoples of Hawaii, Guam, Samoa, or other Pacific Islands (4)

White: A person having origins in any of the original peoples of Europe, the Middle East, or North Africa (5)

\section{Q6 What is your ethnicity? (Check only one)}

Hispanic or Latino: A person of Cuban, Mexican, Puerto Rican, Cuban, South or Central American, or other Spanish culture or origin, regardless of race (1)

Non-Hispanic or Latino (2)

Q7 If you feel that your racial or ethnic background is not listed, please describes how you identify your race and/or ethnicity.

Q8 What is your highest degree level (choose the one that best describes your salary classification)

BA/BS (1)

$\mathrm{BA} / \mathrm{BS}+15(2)$

MA/MS (3)

$\mathrm{MA} / \mathrm{MS}+15(4)$

MA/MS +30 (5)

MA/MS +45 (6)

EdS (7)

$\mathrm{EdD} / \mathrm{PhD}(8)$

Q9 My graduate degree is in the area of.

administration (1)

counseling (2)

curriculum and Instruction (3) 
early childhood (4)

library/media (5)

reading (6)

special education (7)

Q10 What are your levels of certification? (check as many as apply)

Early Childhood (1)

Elementary Education (2)

Secondary (content area) (3)

Special Education (4)

K-12 content area (5)

Q11 I am currently teaching in a (n)

preschool (1)

elementary school (2)

middle school (3)

high school (4)

alternative school (5)

Q12 Approximately how many students attend your school?

less than $300(1)$

$301-599(2)$

600-899 (3)

$900-1199(4)$

$1200-1599(5)$

$1600+(6)$

Q13 How many years of full time teaching experiences do you possess?

Q14 How many years of experience do you have at your current school?

Q15 Have you ever mentored a teacher candidate from Moutaskis University? 
Yes (1)

No (2)

Q16 Which best describes your school's designation?

Professional Development School (1)

Professional Development Partner School (2)

Non-Professional Development School (3)

I am not sure (4)

Q17 Do you actively participate in a professional learning community that is supported by professional development school programs?

Yes (1)

No (2)

Q18 Please describe your present feelings about Moutaskis University teacher candidate preparation.

Very Satisfied (1)

Satisfied (2)

Neutral (3)

Dissatisfied (4)

Very Dissatisfied (5)

Q19 Please describe your present feelings about your relationship with Moutaskis University.

Very Satisfied (1)

Satisfied (2)

Neutral (3)

Dissatisfied (4)

Very Dissatisfied (5) 
Q20 Please indicate to what extent each of the items listed below influence your decision to participate as a teacher candidate mentor. Please note some reasons are personal and some are candidate characteristics.

\begin{tabular}{|c|c|c|c|c|}
\hline & $\begin{array}{l}\text { A very important } \\
\text { influence (1) }\end{array}$ & $\begin{array}{l}\text { A somewhat } \\
\text { important } \\
\text { influence (2) }\end{array}$ & $\begin{array}{l}\text { Not a very } \\
\text { important } \\
\text { influence (3) }\end{array}$ & No influence (4) \\
\hline \multicolumn{5}{|l|}{$\begin{array}{c}\text { I consider it a professional } \\
\text { obligation (1) }\end{array}$} \\
\hline \multicolumn{5}{|l|}{ It is a time commitment (2) } \\
\hline \multicolumn{5}{|l|}{$\begin{array}{l}\text { I can contribute to the overall } \\
\text { preparation of teacher } \\
\text { candidates (3) }\end{array}$} \\
\hline \multicolumn{5}{|l|}{$\begin{array}{l}\text { I can be involved in teacher } \\
\text { candidate preparation (4) }\end{array}$} \\
\hline \multicolumn{5}{|l|}{$\begin{array}{l}\text { There is anxiety/ stress } \\
\text { associated with mentoring } \\
\text { teacher candidates (5) }\end{array}$} \\
\hline \multicolumn{5}{|l|}{$\begin{array}{l}\text { I am committed to improving } \\
\text { the field of education (6) }\end{array}$} \\
\hline \multicolumn{5}{|l|}{$\begin{array}{l}\text { The teacher candidates come } \\
\text { prepared with the appropriate } \\
\text { content knowledge ( } 7)\end{array}$} \\
\hline \multicolumn{5}{|l|}{$\begin{array}{l}\text { Teacher candidates exhibit } \\
\text { professionalism (8) }\end{array}$} \\
\hline \multicolumn{5}{|l|}{$\begin{array}{l}\text { The teacher candidates come } \\
\text { prepared with the ability to } \\
\text { plan and deliver lessons } \\
\text { effectively (9) }\end{array}$} \\
\hline \multicolumn{5}{|l|}{$\begin{array}{l}\text { It is an opportunity for me to } \\
\text { sharpen me own professional } \\
\text { skills (10) }\end{array}$} \\
\hline $\begin{array}{l}\text { I do not receive monetary } \\
\text { compensation for mentoring } \\
\text { teacher candidates }(11)\end{array}$ & & & & \\
\hline
\end{tabular}


Q21 Please explain how professional obligation influences your decision to mentor teacher candidates.

Q22 Please explain how the expected time commitment influences your decision to mentor teacher candidates.

Q23 Please explain how the preparation of teacher candidates influences your decision to mentor teacher candidates.

Q24 Please explain how your involvement in teacher preparation influences your decision to mentor teacher candidates.

Q25 Please explain how anxiety/pressure influences your decision to mentor teacher candidates.

Q26 Please explain how your own personal commitment to improving the field of education influences your decision to mentor teacher candidates.

Q27 Please explain how teacher candidate content knowledge influences your decision to mentor teacher candidates.

Q28 Please explain how teacher candidate professionalism influences your decision to mentor teacher candidates.

Q29 Please explain how you view teacher candidates' ability to plan and deliver lessons as it influences your decision to mentor teacher candidates.

Q30 Please explain how the potential opportunities to sharpen your own skills influence your decision to mentor teacher candidates.

Q31 Please explain how the lack of compensation influences your decision to mentor teacher candidates.

Q32 Would you consider mentoring a teacher candidate from Moutaskis University in the future?

yes (1)

No (2)

Q33 Please discuss the reasons that you would or would not consider mentor a teacher candidate. 
Q34 Please provide general comments or suggestions to improve your experiences as a cooperating teacher, the Moutaskis University College of Education Office of Clinical Experience and/or teacher preparation programs. (optional) 
Invitation to Participate in Focus Group - Email

\section{Participant Letter - Focus Group}

September 26, 2013

Dear Participant,

This letter is a request for you to take part in a research project to identify the factors that influence teachers' decision to mentor teacher candidates. This project is being conducted by Kristi James, in the Office of Clinical Experiences and Professional Development Schools in the College of Education at Moutaskis University. Your participation in this project is greatly appreciated and will take approximately 60 minutes to participate in a focus group.

Your involvement in this project will be kept as confidential as legally possible. All data will be reported taken together. You must be 18 years of age or older to participate. I will not ask any information that should lead back to your identity as a participant. Your participation is voluntary. You may skip any question that you do not wish to answer and you may discontinue at any time. West Virginia University's Institutional Review Board acknowledgement of this project is on file.

I hope that you will participate in this research project, as it could be beneficial in understanding the impact of grades on student life. Thank you very much for your time. Should you have any questions about this letter or the research project, please contact me or Dr. Adriane Williams, who is supervising this study. Dr. Williams can be contacted via email at adriane.a.williams@gmail.com or by phone at (901) 249-7259, and I can be contacted at (304) 696-3100 or by e-mail at k.m.james@ access.k12.wv.us .

Your feedback is important. Therefore, we invite you to participate in the focus group to be held on (TBD) at (TBD).

Thank you for your time and help with this project.

If you have any questions about the focus group, please contact Kristi James at

k.m.james@access.k12.wv.us at 304-730-5425.

Thank you.

Sincerely,

Kristi M. James 


\section{Focus Group Protocol}

In an attempt to obtain a global point of view, the researcher used both survey and focus groups. Surveys assume that people can quantify how they feel, but sometimes they need to process the information verbally. Sometimes it takes listening to the opinions of others in a small and safe group setting to help form thoughts and opinions. Focus groups seemed to be a good fit for this type of conversation to take place. The focus groups revealed a wealth of detailed information and deep insight to the information provided by the survey. Surveys are good for collecting information about people's attributes and attitudes but if you need to understand things at a deeper level then use a focus group.

Protocol:

$>$ The groups will meet for no longer than 60 minutes (Timeframe strictly honored.)

The groups will contain no more than 12 and no fewer than 8 members.

The groups will be representative of the participant population.

$>$ Group members were intentionally selected. The teachers that participated in the focus group volunteered or stated that they would like to share more information in a focus group or individual interview. The group is highly representative of the population used for the initial survey.

$>$ The focus group will be conducted with two evaluators. One evaluator will ask the questions and the other to record actual conversation and his/her observations of group behavior.

The Evaluator: (Script)

Good morning/afternoon!

Thank you for taking the time to meet with us. We will honor your time by making sure that we wrap up in the next 90 minutes. Does anyone mind if we tape record this for our records? We will not share the tapes with the Clinical Experience Staff or your building administrators. I am a researcher, currently completing the requirements for an $\mathrm{EdD}$, and my area of interest is teacher preparation. More specifically, I am researching the factors that influence the decisions of teachers to mentor or not to mentor teacher candidates. Our evaluation is quantitative and qualitative. This means that our primary point is to gather information that will help shape the placement of teacher candidates; and that the information we are collecting is by design is both 
descriptive and numeric. We have a system for quantifying qualitative information, but for now, we do not need to be concerned with counting thing. We just want your words and your impressions. All information we collect is confidential as to who provided it. For example, we will not disclose who actually participated in this focus group nor will our final report make any attributions for quotes. We hope this encourages you to speak freely. Our evaluation will result in a written report by November 1, 2013. This report will be delivered to my dissertation chair for review before defended to the entire dissertation committee. Any questions before we start?

1. After reviewing the survey, I noticed that several teachers stated that they participated in Moutaskis University sponsored/facilitated PLC initiatives, but were unsure if they were in a PDS school. Can you speak to why teachers maybe unsure of the PDS/Non-PDS status?

2. After reviewing the data from the questionnaire, I noticed some conflicting answers. In the Likert scale, questions there were distinct delineation of what factors were influential for teachers' decision-making; however, it was difficult if the influences were positive or negative when compared to the open-ended questions. So could you please tell me:

a. Why do enjoy mentoring teacher candidates?
b. Why don't you like mentoring teacher candidates?

3. Is there anything that I did not ask you that you would like to share with me for the good of the study?

Thank you for your time. 


\section{E. Focus group transcription}

FACILITATOR: Kristi James

Facilitator: Good morning. Thank you for taking the time to meet with us. We will honor your time by making sure that we wrap up within the next 90 minutes. It will actually take ... does anyone mind if we tape record our records?

Group: No.

Facilitator: Thank you. We won't share the tapes with anyone from the Office of Clinical Experiences or Moutaskis University. This is simply for a research project. Currently I am completely requirements for an EdD. moreover, my interest is teacher preparation. More specifically, I am researching the factors that influence the decision of teachers to mentor or not to mentor teacher candidates. Our evaluation is quantitative and qualitative. This means that our primary point is to gather information that will help shape teacher candidate placement and teacher preparation. By design, this is both a descriptive and numeric study.

I just want to make sure that your words and impressions are understood. Therefore, as in the beginning I gave you a number, I would like you to refer to yourself as that number before you speak. No question is directed to one person. Anybody can answer and as many people can answer the same question. It is totally fine. As many opinions as we can get is great. I encourage you to speak freely. Again, my evaluations will be used confidentially. The written report will be in result November 1, 2013, and I will get it back to your contact in the school so you can at least see some of the information that I was able to derive. It won't just be from this school, it will be from all of the schools that foster mentorship for teacher candidates from Moutaskis University. 
After reviewing, the survey I noticed that several teachers stated that they participated with Moutaskis University sponsored or facilitated PLC initiatives, but many of the teachers were unsure if they were a part of a PDS school. Can you speak as to why teachers may be unsure of their PDS or Non-PDS status?

Focus Group Participant \#1: Sometimes the coordinator may not let the school staff know that they are part of the PDS school. There may not be enough communication between coordinator and the staff.

Facilitator: Anyone else have any thoughts first between PDS and PLC's and how they are delineated in schools?

No reply.

Facilitator: After reviewing the data from the questionnaire, I noticed that there were some conflicting answers. In a Likert scale, for example, questions that were very distinct delineation of factors such as professional obligation, time commit, commitment to the field, those things were considered as factors or things that influenced positively or negatively. So could you please tell me why do you mentor teacher candidates if you do? Why do you do it?

Focus Group Participant \#3: I like to mentor students because I think that they are better prepared when they actually go out into the field on their own. I think that we kind of teach them "tricks of the trade" that the university classes do not teach them.

Focus Group Participant \#8: I had a great experience student teaching and I would like to give that back to someone else. 
Focus Group Participant \#11: I like having teacher candidates because it keeps me on track. It keeps my skills going and it keeps me enthusiastic because they come with great ideas and it gets me pumped up at the end. I like that.

Facilitator: Anybody else?

No reply.

Facilitator: Why do you like mentoring teacher candidates?

Focus Group Participant \#2: I think that when they go through their classes in college it doesn't really show them the whole picture of what teaching is about. Therefore, I really like them getting to see all the different things that you deal with as a teacher. It's not raising your hand, "yes, and ma'am “," no ma'am" all the time. It's not a perfect world so I think a lot of times they think that that is what they are going to come into. I think it is good to see all the different situations that they will have to juggle.

Facilitator: Anybody else have anything they want to add to that?

Focus Group Participant \#9: To extend to what \#2 just said, I think it is flexibility as well, because as a classroom teacher you do juggle so many things. Yes, you have your lesson plans set before you but there are so many things that can happen. There could be an assembly, there could be a fire drill, and there could be parent volunteers that come to you. There are so many things that you have to get through in your day and yes, you may not get through your lesson plans but they learn that that is okay. They learn to adjust each day.

Facilitator: Okay. Can you tell me why you do not like to mentor teacher candidates or why you would not want to mentor a teacher candidate? 
Focus Group Participant \#10: I don't like to do it at the beginning of the year because it is really hard to get your class back to being your class if someone else had control of them at the beginning of the year. After the beginning of the year I don't mind having one, I like having them around.

Focus Group Participant \#4: I like having clinical students but I have run into ... there is one I can remember that didn't know basic nursery rhymes. One in particular she would say the word mallard and she would say it 15 times throughout the whole story. Then she missed the next day and I read the story to the kids and then when she came back the next day and they were correcting her on how to say the word mallard. So she wasn't ready to be doing a reading block.

Facilitator: Okay. Reading block, just to be clear, since we are doing a focus group. Reading block is very different than being a teacher candidate. Reading block is a 75-hour placement. A teacher candidate is the whole 8 weeks. Anybody else have any other reasons why they would not be interested?

Focus Group Participant \#5: I do not care to have them because occasionally you will get a good one but my experience most of the time they aren't. I really have a hard time dealing with an adult telling them ----------and you are almost at the end of your education and to tell them that they are in the wrong field that you don't.... to be a good teacher you do not have the rapport with the students and I have a real hard time with that. That's why I don't like to take them.

Facilitator: You have a hard time telling them or you have a hard time dealing with the incompetence?

Focus Group Participant \#5: Both.

Facilitator: Both okay. 
Focus Group Participant \#5: And like she said at the beginning of the year that is hard but then we are getting ready for the WESTEST at the end of the year and if you get one that is weak it is really going to hurt you. It is kind of a risky business; you don't know what you are getting into.

Focus Group Participant \#9: When I did my student teaching experience, I put everything into it. I came early, I stayed late, and it was my job even though I was not paid. That is how I treated it. As a younger teacher, I find that everyone should do the same thing but I am finding that that is not always the case and that some of the student candidates are not willing to put in the work or effort and they still put a lot of the weight on the classroom teacher. Yes, it is my classroom, however, I am supposed to be molding them and shaping them into a future classroom teacher. But I want them to be willing to be shaped. Sometimes you may receive an email saying, "I don't feel well today so I'm not coming in" or they show up late or they want to leave early. They want it to be on their own schedule. When I feel like I have invited you into my classroom and you should work with me.

Facilitator: Could you give me some more examples, particularly of how they push off their responsibilities onto the classroom teacher? Anybody can answer. Again, if you know of any in particular.

Focus Group Participant \#9: Last semester they were required to do a unit study and I know throughout their college experience, throughout the various education classes they are supposed to put together unit studies and when the person came to me, they acted as though they had never done one before. They were not sure how to put one together. When they put it together the language.... there were a lot of grammatical errors I had to correct because I knew their supervisor and I knew her expectations and how high they were and they should be. So things like that where she was unaware of how to perform something or how to execute things that she 
had been taught along the way. I felt like I had to pick up the slack and help her create her own unit when it should have been done. She should have been doing it herself. 


\section{F. Narrative Answers to Open-ended question \#21-33 (Entire Population)}

\section{\#22 Please explain how the expected time commitment influences your decision to mentor teacher candidate...}

It does not influence it much unless it is the very beginning of the school year when everything is very hectic.

It must come at a time in the semester when I can handle the added responsibility of a teacher candidate.

Teachers are incredibly busy, it does take a lot of time

Teachers have so much busy work and paperwork, when students come ill prepared it makes things more difficult.

There is not enough time now to do everything I need to do.

Candidates must spend as much quality time within the classroom as possible. The course work is important, but unless they have the opportunity to truly experience children and the realities of the educational system and society, they will not be prepared to meet the needs of children.

None

Worth it.

I do not feel that accepting a teacher candidate has a huge impact on time, other than the loss of some personal and team prep time, which ends up being devoted to collaboration and reflection with the teacher candidate. Overall, I do not let the issue of time impact my decision to accept a teacher candidate.

Not at all.

We are all in this together. Time is not an issue.

If I have too many projects going on, I may give a teacher candidate to another teacher. There are not many science education candidates so I usually take a couple.

time commitment is not a factor, your there to do a job and help others

It takes time to help develop teachers.

I do not feel it consumes that much more of my time.

It is not a lot of extra time. 
This is not an issue.

The time commitment does not influence my decision.

Not an influence.

Not a lot of time other than when I am already at work...

It doesn't. I have the time.

Whatever time it takes to accomplish the goal

I realize I must make time to do those things that are important to my profession and the students we serve.

For the period of time that the candidate works in my classroom, I have the additional consideration of another teacher, which takes time.

Most of my teachers feel the time commitment for mentoring teacher candidates is not an issue.

I want to do a good job, and it will take time to prepare.

It does not influence my decision. Any time that I take planning with the teacher candidate is time that I would have spent planning anyway. Any time that I need to fill out evaluation forms is made up while the teacher candidate is teaching.

The time commitment is not an issue as long as everyone is improving the lives of the students.

I view this more as a scheduling issue; there are times of the year that are better for a teacher candidate.

Most of the expected time can be done during school hours

The time factor is a huge issue, considering the time constraints of our daily schedule. We have certain content area standards which must be met and with the least amount of interruption.

Not a factor in my opinion.

it doesn't really

Even a good teacher candidate requires a lot of time, but if you get a "not so good" one, it is extremely time consuming and can be detrimental to the students in my classroom.

The time is extreme and makes it hard to take care of my own students. 
I do not mind the time commitment. I do, however, find it difficult to have a teacher candidate in the first half of the first semester of the first semester as it is the first school experience for many of my students and I need that time to establish routines.

Handing over my classroom to someone, I do not know for an extended time period is a hard choice in a time when the number of CSOs you cover and how well you cover them is heavily stressed. I have to ask myself if it is worth the risk of having someone who really should choose another profession and having to take the time to re-teach the things they attempted to cover.

It is difficult to commit time with all the changes with common core.

It is acceptable to put in the extra time needed if the candidate is also willing to put in the time needed.

There is no additional time commitments.

There is often a lot of extra time involved with helping teacher candidates, some need a lot more time than is often a lot of extra time involved with helping teacher candidates, some need a lot. Nevertheless, there is a big payoff for my students.

It does require more time but I can get it done.

This is part of the teaching process.

I am extremely busy and if I do not feel I can put in the time commitment to be the for the candidate, then I should pass it on to someone who can.

Having a student in my classroom does take some time, but that would not cause me not to help.

It does take more time than I imagined mentoring a teacher candidate. Some need more mentoring than others and it does become difficult to share important details on days when other obligations take over, planning time, duties, etc.

I don't look at the time because it is part of a learning experience that takes place daily in the school setting

lots of extra time needed

It does not. It is important enough not to matter.

Being a mentor teacher requires your time and if you do not have the time to spend training and mentoring the candidate then it can be a stressful situation.

It takes a great deal of time mentoring these young teachers, lots of questions to answer and materials to explain and introduce. It is a constant throughout the day with your candidate without any compensation. I feel we offer class worthy education to these young teachers and get nothing for it.

It does require time, and I am willing to take the time. I find teacher candidates are not willing to take the time they need to make the 
commitment.

There is a time commitment because I feel I need to cater to the teacher candidate as well as my students

doesn't

$\mathrm{n} / \mathrm{a}$

I already put in extra hours planning for my students. It is difficult at times, but the importance of mentoring overshadows the added workload.

The time commitment is necessary in order to help the candidate gain the opportunity.

Not a huge deterrent, as long as the candidates do not need mentoring in all aspects, i.e. what the university has already taught them.

A large majority of your planning time is used daily to assist the teacher candidate with the necessary resources needed to do a good job with the students. I still feel responsible for the content presented to the students and I must be sure the content standards are covered adequately.

There is a time commitment but that does not bother me. I do not mind the extra time needed.

A good teacher will not have to change anything in their classroom in order to mentor a teacher candidate. They should just be embraced, welcomed, and made part of the classroom already in progress.

Mentoring a teacher candidate does take some time however, it is important we take the time to create

It does take time to prepare and work with a teacher candidate. I would not have been able to take on one last year while also working toward my national board.

Right now, I feel I do not have time to devote to teacher candidates because I am still trying to get myself oriented.

Teaching is often a 12 or more hour per day job that may include weekends as well. Mentoring appropriately means added time for the candidate and your work still needs to be done. Home life and family too often takes a back seat to our work.

It does not affect or influence me in any way. Time management is essential regardless of mentoring or not.

The time commitment is not important to me.

The time required is minimal as far as paper work, etc. However, the requirements that the MU student must meet is sometimes a struggle to fit into the daily schedule 
Part of the job and giving back time to other that we give to me

It makes me reluctant to accept anything above a Level 1 because I lose time to cover material and it makes my job more difficult with no compensation.

The time commitment is not really a factor for me but I do prefer placements that are not in the first 9 weeks of the school year. The opening weeks are precious time for establishing routines, procedures, and rapport. Selfishly, I do not want to lose it.

I am not bothered by the time commitment when the candidates are sound.

I have only had students for their observation clinical, but it is sometimes exhausting having another person with you all day long. It is nice when there are several in the building and they can all eat together to give both of us a break from being constantly together.

While it takes a great deal of time, it is important to do.

The time commitment is not a worry for me.

A teacher is alongside the candidate guiding them.

I realize there is time commitments involved when I commit to mentor a teacher candidate. I feel that the time I commitment is well spent in preparing a teacher candidate for their career.

The is time involved communicating with the teacher candidate about my objectives for the students ,the students themselves, prep time for planning lessons that meet the objectives and the use of differentiated instruction to meet all of the student's needs. Common Core and the Quad D classroom will need to be explained if there is no prior knowledge. Classroom management skills usually need to be monitored and input given often as well as modeled for the candidate.

It does take more time out of an already time crunched day. In addition, students learning pacing can be affected.

It is not a major time factor for me.

It does take some time and commitment, but we were all starting out at one time.

Takes my prep time while they are here; must do extra before or after school

It is very time consuming depending on the teacher candidate. We are busy enough and to add anything is difficult. However if the teacher candidate is cooperative and professional it makes it easier.

I am always aware of how much time I can allow to go towards the students vs. my students so that neither gets short-changed.

I do many things that are important that take time 
Time is not a factor for me. I do not mind to put effort into helping shape the teachers of our future...

time is never an issue

I have a family I want to be home for as much as possible. I want to make sure I have time to do all that has required of me as teacher and mentor DURING the school hours.

I am a teacher leader at my school so it was difficult at times to finish my duties at the school, for my students, and instruct my teacher candidate during my 40-minute planning period. My teacher candidate(s) would often times have to leave right after school to go to work so I could not instruct them then.

I feel that I have to be very on task so a new teacher knows what to expect when they become a teacher.

It depends on what is going on in my personal life - how much time I have to take things home to work on since I give up school time to work with the teacher candidate.

Holidays and scheduling sometimes interferes.

I am not concerned about the time because I enjoy working with young people.

It does not.

I do not mind committing a little more time to help a student.

It is somewhat time consuming, and often detracts from normal classroom preparation and planning. The added duties can be a distraction.

I realize that it is a time commitment, but also realize that it is a life commitment to the teacher candidate. I hope to positively influence and help guide those who work with me.

There have been semesters that I have been unable to have a teacher candidate because of illnesses in my family.

I enjoy having a Moutaskis student in my classroom to help us for 35 hours, but would never want someone in my room on a full time basis.

Educating future teachers is completely worth my time. This person will teach my children, my grandchildren, and many more. I want to offer any assistance that I can to ensure proper readiness. Teachers need to draw strength and ideas from those around them. I believe the teacher candidates can help me gain insight into what new teachers need. In turn, I can provide my experiences and expertise so they can translate that into something that could work in their future classroom.

The time commitment involved is not an influence in my decision to mentor a teacher candidate. 
The trade-off of not having to plan myself evens out the time spent on conferencing and completing reports for the candidate.

Teaching is an endless task, I do not measure it in minutes, or hours - that would drive me crazy.

No influence

As a Special Education Teacher, I take time to work with the teacher candidates in all areas necessary. It is not a burden at all.

I am always busy. A little more doesn't hurt anything when you can make a difference

Scheduling time to reflect is extremely important. The extra time that this process takes is worth the outcome.

I have to balance my schedule with the time I know I will commit to giving a teacher candidate. He or she is my responsibility in the time they are with me. If I cannot give a candidate ample time to confer with me, review plans, discuss presentation of lessons and strengths and weaknesses then I would rather not mentor. It is a disservice to a candidate to place her in a classroom where she is not supported. This is the time a candidate needs to feel free to ask all questions and receive a seasoned teacher's responses and support.

It is time consuming, but worth the intrinsic feeling.

It is time consuming if done correctly. The teacher must be prepared for the teacher candidate.

It takes time, but it is worth it.

It is time consuming and requires some extra work.

If my year is looking overbooked, I am less likely to say yes.

To do a good job, one must be willing and have time to commit to mentoring.

Sometimes it is difficult to have units timed in such a way that the teacher candidates get what they are required to have for their portfolios. Some teacher candidates have also bulked at teaching more than one or two units, despite the amount of time they still had left in their placement. I understand that they can be teaching from my own lessons, but I think there needs to be a clarification from the University that they are supposed to be doing all they can now, while under the guidance of another teacher, instead of getting by with the bare minimum.

I want to make sure I can give the student what he/she needs as help along the way.

It really has not been an issue up to this point.

The time each teacher can commit to being a mentor teacher can change from school year to school year depending on other commitments. 
Time commitment has no influence on my decision.

\section{\#23 Please explains how the preparation of teacher candidates influences your decision to mentor teacher...}

If they are prepared, it makes an easier transition into the classroom and into teaching.

I am hesitate to take on another teacher candidate due to lack of preparedness

Teacher preparation is extremely important.

Candidates need to be preparing to work with students and have a deep understanding and usage of curriculum. They truly need to utilize basic skills to be able to teach elementary school. Some candidates have poor usage of grammar and do not have skills to communicate with students. I am able to teach candidates routines, procedures and classroom management strategies, but I should not have to teach them how to use correct English. Educators are models for children. We must produce quality student candidates.

The experiences I have can greatly contribute to the success of teacher candidates. There is no substitute for real world experiences.

Assists with teacher sustainability.

Before accepting a teacher candidate, I like to receive information relating to the individual, their philosophy of teaching, etc. However, such communication is not consistently made available and often it is very generic. Also, after reviewing expectations and course syllabi from students completing Level I and Level II assignments, I have found myself dismayed with the disconnect between what teacher candidates are learning in college and what being a teacher in the 21 st century is actually like.

I want them to have a great work ethic and expectant of constructive criticism so my students can be properly prepared.

If an individual has, a desire to do what is right then we want them at our school. I would rather have a candidate who lacks preparation, but has a desire to help students then to have a teacher who is very well prepared, but does not care about the kids.

I think Moutaskis does a good job and I really have not had an unprepared candidate.

All of my teacher candidates have been very well prepared. it has been a pleasure to help them

Some don't seem to be as prepared as others and I wish to show them how important preparedness s in teaching

I want to see that candidates can be great teachers.

All it takes is to get one unprepared student to make you rethink what you are doing. However, most of the students we get from Moutaskis are very well prepared. 
The candidate's willingness to learn and coach ability is what matters.

I am not certain how much I can contribute to the preparation of teacher candidates when they have their own styles and mindsets about teaching.

It enables them to see reality finally

I do not feel I can answer this question, because I have yet to be a mentor to a teacher candidate.

The same as answer one

MU has a quality program, and I feel that quality mentor teachers are key components of that program.

I do not want another student. I want someone who is almost ready to be a teacher and that takes knowledge.

I feel that if a teacher candidate is well prepared by the institution then it will make the student teaching process much more successful and more teachers will want to continue mentoring teacher candidates.

I want to help the teacher candidates be better prepared for that first day that they enter the classroom.

It can be frustrating when the candidates do not have some needed knowledge.

I feel that most of the candidates I deal with cannot teach the subjects I teach.

I want all mentor teachers to feel successful so that they can be successful on their own

If a student comes to us and has been offered a successful pathway to be placed at a school the job of preparation should not be too difficult. If the student is not prepared, the regular classroom teacher can spend lots of time trying to undo the damage.

I must use all time given to me in a day to teach my classroom students if a teacher candidate is not prepared or committed to take time to do what she/he must do as a teacher candidate I cannot take the time to reteach the lessons over that they must provide in the eight weeks they are a full time teacher in the classroom.... therefore they must be ready!!

they come focused on things that don't really matter; lesson plans for example are done differently everywhere

The last few teacher candidates that I have had did have the knowledge of the subject matter, but were not committed to the preparation that it takes to be a teacher. He did not read the chapter before he tried to teach the unit. He used my materials without previewing them.

Teacher candidates refuse to do less plans. Unheard of! 
I simply want to provide an opportunity for candidates to have an authentic experience and an opportunity to explore and experiment.

I feel that Moutaskis does a great job preparing teacher candidates for the classroom; however, I DO NOT feels that Moutaskis does an adequate job weeding out those who do not belong in the profession.

When you have difficulty with one, it makes you not want to have another one.

Some candidates I have mentored are very well prepared. Others, however, are somewhat lacking in preparation. We work together to "catch up."

All teacher candidates I have received from Moutaskis have been very well prepared. My only advice to all of them would be classroom management. I think that comes with experience. It is also difficult for them to establish that when they are only in the classroom 6-8 weeks.

It gives the opportunity to let them know what having a class is truly like and what they can expect getting ready to take on their own class.

It is always a risk. You never know what type of person you will get. Some come ready and work hard every day. Others come with little drive and may not even like working with children.

I want to help fill in the gaps.

Preparation is a crucial part of teaching

I do not expect them to be $100 \%$ efficient, because school never completely prepares you got the real world... Only life can do that. I do expect them to have content knowledge and the desire to learn.

After learning, all they do in the classroom the teacher candidates need time to try those out in a classroom.

I cannot deny that I have tried to manipulate WHO comes to my classroom based on how prepared they are to enter a classroom and work ethic. It is scary to allow someone into the room that may not be prepared.

It gives us an opportunity to teach the everyday activities that are not taught in higher education.

They need to be well versed in the latest methodologies and best practices.

Teacher candidates should have some background information to bring into the classroom.

Everything you do you have to explain in detail. This takes an enormous amount of time out of your workday. My planning periods are not mine any longer therefore I find I take things home more often and work on my own time just to help them.

The last teacher candidate I had showed little interest and effort. I have really debated having another teacher candidate. 
I'm not going to lie, the teacher candidates I have had have been terrible, they were both switching out of my certified area, one going to Med school and the other dropping down to elementary education and neither wanted to be there

allows me to see where improvements need to be implemented that often are missed in the ivory tower

With a good MU supervisor, my job is easier.

I think the classroom experiences are one of the most important parts of teacher education.

For the most part, candidates are prepared, but the process of student teaching identifies weaknesses.

Difficult question as I know the university prepares the candidates the same way but many are not at the level they need to be when they enter our classrooms - much of this is lack of maturity and not university's fault.

I feel that I work daily to prepare my students to be ready to progress to the next grade. The teacher candidates often provide a new perspective on how lessons can be presented to the students.

I feel that I have experiences that will help give them positive influence for training necessary to become a great teacher.

As with time, I need to have the opportunity to prepare.

I feel that the most practical preparation comes from student clinical. Therefore, preparation through coursework is not a critical factor for me.

Too many times, I have heard 'that's not how we were taught to do that', or we were never told about that. Often times the teacher candidate has missed key concepts that should have become evident to them before entering the classroom.

Certainly, if the candidate is not prepared it will reflect in their evaluation so this has little to do with me and more with the program and the candidate his/herself.

Moutaskis students are usually prepared adequately for their student teaching. There are always a few that seem to have gotten to this point without having "what they need" but that is where we teachers need to step up and guide them as best we can to be ready for the classroom.

I have had good experiences with the candidates so far.

Get to learn new ideas

If I have a candidate that is much unprepared then I will refuse to have future candidates for a very long time.

I recognize part of student teaching is learning how to be prepared so I expect teacher candidates to come prepared but not so prepared they are unable to be flexible and adapt. 
I have had great luck so far with the nature of teacher candidates from Moutaskis. Therefore, this has yet to be a deterrent to my election g to accept TCs.

It greatly influences my decision. If the teacher candidates are not prepared well, it feels like I am wasting instructional time. I am also concerned that Moutaskis does not always prepare teacher candidates to come in and take over a classroom in accordance with Cabell County's mandates and therefore my classroom is out of compliance with my county directives. I do not know how to fix this because I realize Moutaskis is not preparing students to only teach in Cabell County Schools, but we are heavily monitored and it is important that our classrooms comply with county mandates.

I have found a number to be unprepared; therefore, I feel that it is my job to help prepare them.

I have 24 years of experience and I want to share that with future teachers.

I have a lot to offer in the way of experience.

I feel like many veteran teachers are refusing to mentor new teacher candidates. These students will be our substitutes and coworkers soon. I want to help prepare them to become excellent teachers.

I do think the candidate must apply what he or she has learned to an actual classroom.

They need to come to the schools prepared.

I want to make sure that I get candidates who know what they are doing.

They should be prepared to a point, but then that is why they are placed with us so we can help them.

Feel strongly that new, well-prepared teachers are needed

They need to be prepared in order to get the most out of this experience. If they are not it is not a good experience for anyone and it makes it difficult to participate.

Teachers should be prepared

I love working with clinical students. I feel that they can teach me just as much as I can teach them.

the prep work is very little

If candidates are not prepared it will make my mentoring more time consuming.

How prepared the teacher candidate is dictated how much more time I need to spend with that teacher candidate when helping them with content knowledge or basic teaching strategies. 
I really feel that if a student has reached the stage in his career to do student teaching then I expect his best.

Teacher candidates are very familiar with the state standards and common core so we can focus on other areas.

I would like to see teacher candidates more involved with technology.

If the teacher candidate is well prepared it gives my students another approach to learning. In addition, it gives me new ideas to use with my class.

New teachers must see how the classroom really is.

I feel that they should be somewhat prepared but they are coming to you to learn how to actually run a classroom so it is not realistic for them to know everything. As a teacher, I should teach them these things.

I no longer accept teacher candidates. My experience with these individuals has been "mixed"; at best. My biggest concern is work ethic.

I have heard that Moutaskis more than prepares their students for the classroom.

All of the teachers that I have mentored have been excellent and so I am not hesitant to agree to help.

Because I work with the students at an early stage, I realize that they are in the process of getting prepared for student teaching. I hope I can be helpful in this process.

Some teacher candidates are born teachers and have been teaching since they were 4 . Others really want to become a teacher...either way...Y You have to have a starting point. I think that good preparation is evidenced by their actions and ideas...hopefully both are well thought out.

Having worked with teacher candidates in the past from Moutaskis University, I have had good experiences with their level of preparation and their eagerness to begin the experience of fully teaching. Their enthusiasm and organization make it easier to accept a teacher candidate into my classroom and more enjoyable when taking the extra time and effort to provide a meaningful experience as the last step toward beginning their teaching career.

This is one of the biggest factors that influence my decision. I feel that when a teacher candidate comes to me they should have attained skills that are innovative in education. I am there to give them the experience in a classroom and the guidance. I do not want to be the one to show them how to do everything. I want to be the facilitator.

Each student is an individual, so each experience is unique, but a candidate who is serious and prepared certainly makes taking another student easier.

Again, I do not make the final decision - if I do it or I do not, my room is available for any teacher that needs help. 
I want future teachers to be the very best we have to offer society.

Working with new teachers only makes the profession better by allowing those entering the field to be prepared.

I like to help - just as I was helped when I was beginning my teaching.

It does not bother me. I believe that the best way to learn HOW to teach is being in the classroom.

It is beneficial for me to see how the preparation of candidates on the university side connects or disconnects with what is actually occurring in classrooms. I think there are still gaps. This is why I like working with PDS to ensure gaps are closed and candidates receive a streamlined route from university to classroom.

I have not had a teacher candidate but I have had two students who were working on clinical. I had issues with both of them. I think there is a need for immediate contact with a MU supervisor after the first week to discuss inimical problems. One student was immature and could not do simple request, the other did not seem to know dress code (dresses to short) and professionalism (following schedule we set up, calling when not showing up, and not calling when she decided to quit school).

The candidates I have worked with are prepared and ready to work. It makes the job easier.

Usually, MU students are pretty well ready to teach and work with kids.

I do not have time to teach a candidate; she must come prepared and just need guidance.

I remember needing feedback from the teachers I worked under as a teacher candidate. I try to do the same for those who are partnered with me in order to help them be ready for their own classrooms.

It does not influence my decision.

I can learn from new teachers.

It does not.

There is only so much a future teacher will learn in college, this gives them a chance to experience the classroom and ask questions about our jobs.

\#24. Please explain how your involvement in teacher preparation influences your decision to mentor teacher candidates

A portion of my own time as a teacher candidate was negative and I want to be a part of providing a more authentic and positive experience for candidates. 
As the school leader, I try to assist in any way possible.

Being in a classroom takes experience and being in a safe environment to spread your wings is very important

Being involved with teacher preparation is a wonderful way to help the candidates be ready for the classroom. I never want to let a candidate out of my classroom without being confident that they could teach or sub in their own classroom the next day.

Good experiences create great teachers.

Have worked at many levels of teacher prep

I am not entirely sure what you mean by this question.

I have had both good and very poor candidates in the past. Sadly, the latter (due mostly to lack of self-discipline, maturity, work ethic, et. al) has influenced my discontinuation.

I have only been teaching 9 years, so I still vividly remember how important the field experiences and student teaching time was to me. What a student learns in class and what they experience in a real classroom are two different things, so I hope to help my teacher candidates experience the "real" classroom planning experiences.

I always welcome others into my classroom. I usually learn just as much from teacher candidates as they learn from me. It is a chance to collaborate with others in my field.

I am not very involved in teacher prep.

I am one more piece of the puzzle.

I am willing to help others in the preparation process.

I believe I can give them a positive student teaching experience.

I believe that teacher candidates need to have classroom experience beginning the first year they are in school. To get the classroom experience as they prepare to graduate may be too late for them to decide they have no real passion for the classroom. Each semester should have a classroom experience.

I do not know that it does. Each candidate is so different and it is difficult to determine with somewhat influence (negative or positive) I have.

I enjoy being involved, and I enjoy the professional collaboration.

I enjoy being involved in the teacher preparation. It gives me an opportunity to reflect upon my own teaching and share with others. 
I enjoy helping teacher candidates find their own footing, turning my classroom over to them so they can "fly" with a safety net.

I enjoy watching the well-developed teacher candidate's blossom into full time teachers.... I also get to see new trends in education in action as well!

I feel a real obligation to mentor pre-service teachers, but get very frustrated when they will not make the effort necessary to do the best job possible.

I feel I have great knowledge of my subject and want to pass this information along to future teachers to assist them with their teaching careers.

I feel it is important for teachers to be involved with teacher candidates; there are always new and innovative styles of teaching that need to be shared.

I feel like my experience is valued in this process more so than in the actual performance of my job.

I feel sponsoring TCs provides me with a hands on approach to positively affect the quality of educators.

I feel that anything that I learn to sharper my skills should be passed on.

I feel that giving teacher candidates as many experiences in the classroom will make them much better teachers by practicing with actual students rather than by reading about the "perfect world" situations in textbooks. I feel this is important to their learning to be the best they can be.

I feel that teacher candidates get the chance to practice what they have learned and that I may be able to give those ideas as well as them giving me ideas.

I feel the prep program needs good solid individuals to help guide our students.

If it is going to take lots of time and take away from my student learning time, then I do not want to be involved/

If they are getting ready to enter the work force, they need to be prepared. Actions need to be in place to weed out those who would not be effective teachers.

If we want good teachers coming out of our colleges then we have to offer them this kind of experience. Honestly, they need more of this kind of experience especially with writing.

I have enjoyed mentoring Reading block students and would like to mentor a teacher candidate. In my experience, the Reading block students have energized my Reading classes.

I have had good experiences thus far. 
I have had the opportunity to mentor new teachers before and took great satisfaction in helping to mold them into effective teachers.

I have not been involved in this aspect of the process yet because I have not actually mentored a teacher candidate. I have only had students in the observation stages of their coursework.

I have worked with teacher candidates completing observation hours, but this will be my first time working with a teacher candidate.

I help lead STEPP sessions for teacher candidates. This gives me a real stake into teacher preparation, so I am highly motivated to mentor them one on one.

I help mentor because I remember how helpful a few pointers can be.

I hope in some way I can help the candidates to become better teachers.

I know what is expected of the TC.

I know what new issues are facing regular teachers so I can pass on what I know to new ones.

I like to re-think the way I am doing things, try new ideas, and bounce ideas off people. Having a teacher candidate can keep my fresh in my own teaching and encourage them as well.

I like working with people that enjoy the thought of teaching a new generation of students. They give me new insights into how to do my job and in return, I give them insight into what they can expect and hope that they will learn from my experiences in the classroom and school community.

I love being a mentor. I do not enjoy working with students who have issues listed above. I think there is a communication problem and MU is not getting the information immediately so they can meet with the students and fix the problems.

I LOVE to mentor teacher candidates. I remember 15 or maybe more years ago when that was me. I was so concerned about every little criticism I received. I try to be calm and directing without being too degrading. I want to find what they do well, maximize that strength, and address weaknesses in a constructive manner.

In the past, when I have had a good experience with a teacher candidate, I am excited to work with another one. On the other hand, when I have mentored a candidate that was not prepared, I felt like I would not want to be a mentor again.

I spend a great deal of my time helping others become better teachers.

It's hard to let the mentor teacher have full control of the students

It allows me to reflect on what I do daily

It does not. 
It gives the opportunity to give back some of what I have learned on the front lines of education to make it easier for future teachers.

It help to see them grow and become the future

I think it is an obligation to help to profession.

I think it is important that teacher candidates have someone who is positive and interested in bettering our school.

It is always good to be learning and expanding our knowledge because the curriculum changes often and teacher candidates need to know how to prepare for the changes.

It is necessary for me. When asked, I mentor.

It is nice to have a voice in the process.

It is what I am supposed to do.

It makes me want to share my enthusiasm and knowledge.

I train teacher candidate candidates through STEPP and am the PDS coordinator at my school. I mentor all the candidates at my school.

it doesn't...I have no influence over education guides or MU teaching

I want the best and most qualified teachers in classrooms.

I want them to learn well and I can provide that leadership.

I want the teacher candidates to understand the amount of preparation needed for a day of school. You do not just walk in and go by the seat of your pants.

I want to be a part of the future teachers and help them to understand some logistics that they have difficulty with on their own.

I want to help create better teachers, but I do not know how I can do that right now -- because of the classes I teach, I can only accept

Level I clinical students and I do not know the extent of helpfulness that provides.

I want to help other generations.

I would like to be more involved.

Let's candidates learn to work with students 
limited involvement beyond clinical placements

\section{\# 25 Please explains how anxiety/pressure influences your decision to mentor teacher candidates.}

It does not influence me unless there is a candidate that is inadequate ill prepared which makes it difficult to deal with as the public school supervisor.

N/A

Time constraints and added responsibility create lots of stress and anxiety for me.

Any mentor should experience stress while working with teacher candidates because we are responsible for the education of the students in the classroom as well as the preparation for the candidate.

I do not experience anxiety when mentoring.

Doesn't

Accepting a teacher candidate can lead to stress -- if the individual has subpar content knowledge, poor classroom management and lacks true commitment to the profession and the kids. This certainly weighs heavy on me before accepting a teacher candidate.

The teachers are comfortable with being mentors. We love having Moutaskis Students in the building.

There is no more anxiety or added pressure that comes with the job normally. In my experience, having a teacher candidate is like a partnership and helps to alleviate some stress and anxiety.

No anxiety from participation in mentoring

No anxiety for me.

In my experience, teacher candidates can be unprepared and I worry for my students.

Again, anxiety occurs when a seemingly uninterested, unmotivated teacher candidate is placed.

I feel no pressure or anxiety.

No real issue here -- taking on a Moutaskis student is the least of my anxiety as a teacher.

Someone's life...5 plus yrs. rests on your evaluation. 
It does not. I am pretty even keel.

Doesn't affect me what so ever

I do not see any anxiety issues associated with mentoring.

I could feel anxious if I accept a student and we have a personality clash. This is unusual, but it could happen.

Many of my teachers do not feel comfortable mentoring teacher candidates for a variety of reasons.

I feel no pressure or anxiety when I am working with a teacher candidate.

If a placement or candidate is weak in skills and knowledge, it can be frustrating to all involved.

I don't feel much anxiety

I do not feel any anxiety or pressure.

I only have anxiety if the teacher candidates are not ready to be in a classroom... thus far this has only happened once at our school.

It's only stressful when I first meet them, they may not like my style

I am comfortable with other people in my classroom for observations or student teaching.

I get irritated with people who do not give more attention to teaching than they would a job at MacDonald's.

Overall, it does not hinder this decision. This past year it felt as if the supervisor did not truly value my professional views to the point of questioning my procedures and routines. She also spent a great deal of time comparing the candidates, as well as myself to her daughter who is a teacher in the county. This did not help to create a calm working relationship.

I agreed to take on a teacher candidate this fall, but I have felt some anxiety over the decision. I do not know anything about the person that is walking into my classroom. I think these needs to be fixed. This was also an influence when I completed my own student teaching. I did not know anything about my host teacher so I had no idea what to expect from him.

Anxiety from having a teacher candidate that has a poor work ethic, it makes you hesitant

None. Most of the time, the teacher candidates are an asset to my classroom.

After having a less successful experience, I do think about whether the time and effort are worth it.

I am nervous because I am ultimately responsible for my class and their achievement. 
I think this helps to lower the anxiety level of the teacher candidates and I am willing to help.

I worry about doing an effective job!

At times, I feel nervous when others are watching me, but after a while, I get over that.

If I have an idea of the caliber of student coming to my classroom, I do not have anxiety about accepting them to mentor. I also feel comfortable saying no to MU or my administrator if it is not the appropriate time to mentor.

It takes the anxiety somewhat out when teachers know what is expected other than just teaching and lesson plans

It does not.

You want to do the right thing and make them successful.

I do feel pressure because it is up to me to help mold them into the kind of teacher I would allow to sub or teach my students.

The anxiety is dealing with poor teaching techniques, dealing with professional dress, and acting professional.

It puts a lot of anxiety and pressure on me because I have to cater to them when each time none of them have wanted to be there

None

N/A

Anxiety and pressure do not influence my decision.

Some candidates have performed poorly and this can cause major problems in the classroom, but you do not know until they have the opportunity.

NA

When a teacher candidate is unprepared for the classroom setting or he chooses not to take the job seriously, it makes my job as the classroom teacher more difficult. Problems with parents can arise when the candidate does not conform to school policies even after being made aware of them.

I do not feel pressure or anxiety to have teacher candidates in my class. I find it exciting because not only do my students benefit, the teacher candidate benefits and I myself benefit. It is exciting to be able to have teacher candidates in my class.

The teacher candidate may have anxiety and I would have to work with that, but I would not have a problem with it. 
Working with anyone new can cause tension.

The expectations of me in mentoring a candidate adds another level of stress to a job that already takes your full attention in meeting all students' needs. Time truly does call for an entire different prep for the teacher candidate.

No influence.

I feel no anxiety or pressure in my decision. I enjoy it.

\section{Doesn't}

It makes me less likely to take them because I do not get to cover as much in classes that are already difficult to get 3/4 of the material covered appropriately.

When I was the team leader, I hesitated to have a teacher candidate because I had so much more on my plate than just teaching. I agreed to a placement and it turned out to be a great learning experience for my teacher candidate, too. Teachers do so much beyond the classroom, too.

I do not feel pressured by my school to take a TC in any way. I have no anxiety in taking a TC save a small apprehension of receiving a bad TC (which happens sometimes).

It does cause concern for me. I am already pressured to raise test scores, follow county mandates, and control my classroom. It is additional stress to mentor a teacher candidate. I truly want to help and influence our future teachers perhaps in a lecture format, but I do not want to add more stress to my already stressful days by taking a mentor teacher especially if they are not prepared to step in and take over the classroom effectively. Then there is the additional stress of knowing I am losing instructional time with my students. I want to help, but it does add anxiety.

I do not feel pressure.

Any new role will have some anxiety, but I have mentored this past year for a beginning teacher.

It does not.

None

I have never felt stress or anxiety while mentoring a Reading student. I spend time at school after hours to help alleviate taking the stress home.

The greatest anxiety for me is not intervening as I watch a candidate learn from the experience

It takes more time out of the day. Can slow down learning that has to be made up. 
It is not a major issue.

Not major

Being evaluated and observed is not calming for any teacher.

It is a big commitment.

I worry it will hurt my students' education

It normally does not.

Not an issue

How will my students deal with a 'break' in my teaching to have a candidate teach?

I do not feel any anxiety or pressure.

I do not like to feel pressure so I want an individual who really wants to be a successful teacher.

There is no anxiety/pressure due to having a teacher candidate; it is only outside / personal life influences. If my personal life is especially hectic, it usually is not a good time to be mentoring.

Different expectations from candidate. It also depends on the time of year a candidate comes. Reading blocks students vs. teacher candidates.

At times, I worry that since I am considered old school I might not always be doing all the new methods.

It does not.

No anxiety

Though a minimal factor - if the classroom lessons/environment seems unproductive it can put stress on the regular classroom teacher.

I am not worried about the experience at all. I am sure that my teacher candidate will come prepared and willing to learn.

I would not want the pressure of having someone in my classroom all day, every day.

I feel no anxiety or pressure to mentor candidates.

I enjoy having teacher candidates in my classroom. Most of my anxiety comes from not being able to let go enough of my classroom. 
I am concerned about the candidate's performance, but I do not feel anxiety or pressure.

I do yoga - so any anxiety I have is left on the mat!

None

I have no anxiety or pressure about working with teacher candidates.

I do not have any anxiety toward having a teacher candidate in my classroom

As long as the focus is on the students, and time is utilized, there is not much anxiety/pressure.

I do not feel any anxiety or pressure in terms of mentoring candidates. However, I know that the candidates feel a great deal of anxiety and pressure and I would like to alleviate their fears as much as possible.

I enjoy being a mentor and would love to have a teacher candidate. The anxiety comes from wondering if I will see the previous problems again.

I do not experience anxiety influences.

I feel a little pressure in making sure they are ready for dealing with kids.

If I am busy with my career, I will not work with a candidate, as I will not have time to do the job properly.

I have had two teacher candidates in the past who did not take their placement seriously. It has decreased my willingness to want to open my classroom up to another teacher candidate. I have realized, however, that two other teachers took a chance on me and were willing to let me learn in their classrooms. This brings me back to being willing to help teacher candidates be the best they can be - not just get by.

I am a thorough teacher, yet mentoring causes me to question my ability to cover enough material effectively.

Getting a student who just wants a job but is not interested, I making a difference in a student's life bother me.

That has not been an issue.

N/A

The only anxiety is wondering how I am going to get along with the teacher candidate. Personalities are different and I can get along with just about anyone, but it does concern me for the climate in my classroom. 


\section{\#26 Please explains how your own personal commitment to improving the field of education influences your decision to mentor teacher candidates...}

I think our profession should continually improve and evolve. To do so, we need teacher candidates to be involved in the new programs, standards, curriculum, etc. that we utilize in our classrooms.

I want to help teacher candidates experience the full workload of a classroom environment outside of the hypothetical world of their teacher prep classes.

I want to improve the quality of new teachers

Our school has taken on additional challenges and I have personally taken on professional challenges that do not allow me to mentor teachers at this time.

I always consider if I would want my child or grandchild to be a student in the teacher candidate's classroom. It is my job to facilitate and mold the candidate to be that teacher.

Too often, I see teacher not equipped for education of today due to preparation that is stagnant in the past or based upon previous education experiences as students. The time is now to transform education for a meaningful learning process that builds better citizens for tomorrow.

Want to assist with ensuring prepared candidates enter the profession.

As stated previously, when I was involved in the re-evaluation of the MU student-teaching practices and expectations, I felt intrinsically motivated to participate in the teacher candidate program. In addition, I feel that the field of education is very murky and muddled with contradictions, so I do feel that it benefits teacher candidates when they have a teacher mentor who can help navigate them through their first real experience as a classroom teacher.

I want to help teachers be the best they can be. If I can make the teachers better then I will make a lasting impact.

I am very committed. As mentioned before, if I have a busy schedule and too many projects, I may not be a supervising teacher, but would still have them in seminar.

I had wonderful supervising teachers and I believe that you should do the same thing to help insure the next teachers have the same success

I would like to see the children be more prepared when they reach high school therefore real teaching needs to occur not just experiencing. Children do not remember experiences. They remember things that have been taught

I want to see great teachers and I am tired of hearing about schools producing poor quality teachers for the money.

I have grandchildren in the public school system and want the best-prepared teachers to teach them. 
This goes back to my enjoyment.

I am not sure how to answer this -- can I really affect the overall field of education by mentoring one teacher candidate?

It does not. Just try to give students dose of reality...

Unfortunately, not every teacher I have worked with is up to the job. Through mentoring, I can help keep that number as small as possible.

Same as question one

Any job is only as good as those who choose to do it. If we hope to see excellence, we must put forth that level of performance.

Teaching a solid work ethic will help to insure a future of excellence.

As a principal, I see the importance of starting a teacher out on the right path and this gives us the opportunity to change the future of education.

I feel that having a teacher candidate in my classroom is a chance for me to share what I have learned works for me.

As an educator, it is my responsibility to continue educating the future teachers.

I want to help new teachers understand what is required to be successful with today's students.

This is probably the only reason I really want to become involved in the first place. I want our profession to be highly regarded and that will not happen with mediocrity.

We need to support our profession by helping provide the best in the field. These young teacher candidates can only become professional with experience and observations of how to and sometimes not to work with children.

Hand in hand

To get the best new teachers, we must provide them with the best clinical experiences. I feel like I can be a part of that.

I want devoted teachers for our next generation of children!

Students deserve teachers who have had an opportunity to explore experiment and practice in an authentic and secure environment.

The only way that I can improve education outside the walls of my own classroom is to mentor and work with other teachers, whether candidates or seasoned teachers.

I want the teacher candidates to leave the university better prepared than I was. 
I am currently working on Ended. In addition, my administration certificate through MU. I want to help other teachers become successful.

If I can pass on professionalism and passion for education through effective modeling and teaching, others will do the same.

I do not think we can complain about the quality of new teachers unless we are willing to help guide them.

I want to help others in my field for the future of education.

Want to help in the real world experience for teacher candidates.

I got into education to help others; it is ingrained into my DNA.

At times it seems that what the teacher candidates learn in their classes are not always what is going on in the classroom now, so it is good for them to come out and see.

If the teacher is the most important factor in the classroom for student success, and I have something I can share with teacher candidateswhy wouldn't I make that decision that benefits future students? This is the philosophy of education in general, if we weren't mentored, where would we be? We should continue to "pay it forward."

I feel teachers should mentor those entering the field, but they must come to the classroom prepared to work.

I am blessed to be a blessing to share with others.

I think it is a teacher's responsibility to help future teachers.

I feel that my experience and advice can be shared.

I enjoy teaching teachers and have been involved in incredible amounts of PD the last five years and I enjoy sharing it with others, which will benefit all our students.

I enjoy my job and I want to instill the love of teaching to others.

I think it takes a personal commitment to say I'm going to share my classroom for the benefit of my students as well as my school and myself.

I consider it my duty to help others and to make sure that the students are given the best of the best.

I believe that teaching in a teacher-training course that prepares my students to enter the education field at university.

Since I trust in my abilities as a teacher and consider myself a teacher leader, it is natural that I would like to encourage and mentor the 
future teachers recognizing that I may also learn from them.

Not wanting to do any other job since I was 12 years old, has made me very interested in the field of education! If we don't pass on our experience as well as guide candidates, how else can they learn? The textbooks are good for the college classroom, but the real world experience is so important to getting them ready to be teachers. I don't mean sitting and observing teachers in the classroom, but doing every little job that will be required of them when they step into their own classroom.

Helping others by giving them experience

I feel that we should have the best and most knowledgeable teachers and anything that I can do to help that along is important.

As I mentioned in the first explanation, I want to "pay it forward" with my students and with fellow teachers. As a lifelong student, I have experienced the best and worst of teachers. It is my job to try to be one of the best teachers and to help other teachers do the same.

I take seriously the need for veterans to influence the future if the profession. Therefore, I happily accept TCs when asked.

I am very dedicated to improving the field of education, and I want to help, but I think I'm better suited for students to observe me in the classroom and my teaching style, classroom management, etc. and/or discuss with me my philosophies on teaching. I typically enjoy that part of the process, but I just do not think I am comfortable turning over my classroom to teacher candidates.

I feel that many have an idealized view of teaching. I believe that I can display the reality and the joy of teaching.

I love teaching.

Anything I can do to help the profession and help a future educator to become a great teacher.

I have earned a master +68 . I am committed to education.

I feel it is my duty as a professional and a Moutaskis graduate to help prepare new teachers for the workforce.

I am committed enough to share my students, my classroom and my experience if it will be a positive influence on future teachers

Working with MU and communicating with candidates and professors.

I want to share my experiences.

Feel strongly that new, well-prepared teachers are needed

We need good teachers. This profession is becoming less desirable for people. This experience can influence someone to leave teaching which can sometimes be a good thing. 
I like to share ways in which I have been successful, and ways that I have not, for their benefit.

I do a lot to improve the field of education so it does not have much influence

I feel that I have a lot to offer student candidates and I enjoy sharing it.

I want my children to have teachers that are up and coming with new styles of teaching, that is why I choose to be a part of the program.

I believe I have a lot of experience that I can share with a newer teacher.

I want good and prepared teachers out there instructing our future generations. I feel I can help do my part but ensuring the batch of teachers are prepared with the latest teaching strategies, content knowledge, and abilities.

I like to share my knowledge with others.

I have had personal experience with the best and the less than mediocre in the teaching field and I strive to be an outstanding mentor.

I hope that when a teacher candidate leaves my class he/she has a love for teaching and children. Also that when my students leave they have a love for learning.

The field of education must be kept at a high level.

There are still a lot of holes in the system and I want to help young teachers learn how to be great teachers. I came from a different state and a more organized system and I think that these students should be exposed to other systems as well.

My commitment is First to the students in my classroom. Anything that seems to reduce the effectiveness of that process can wait.

As a teacher and as a mother I am very interested in making sure that our current educational system improves greatly. If data and research are correct, WV is failing our kids. I want to work hard to make sure that is corrected and soon.

As I stated before, I very much appreciated those teachers who supervised me while I was at Moutaskis. By "paying it forward" I hope I am having a positive influence on those considering teaching as their profession.

As stated above, I truly enjoy working with teacher candidates. It provides a different type of cadence to the day.

I believe this survey is a great step in preparing teacher candidates. I have had many discussions with other teachers about the fact that so many teacher candidates come to the classroom today wanting to work a certain shift. I don't know of too many teachers that don't stay later or take things home in order to be prepared for the next day. Preparedness comes with experience and I feel that so many teacher candidates fail to put the time in to become well prepared for a day in the classroom.

I think it is better to discourage potential teachers who clearly do not have the level of commitment necessary than to keep someone in the profession who is clearly not professional or capable. A bad teacher is almost impossible to get rid of once they are hired. 
Teaching evolves each year with new expectations, growing and learning - that is how I attack each year, mentoring new teachers seems to coincide with the job.

Already asked

When new teachers come into the classrooms knowing what the needs and limitations are they are more prepared and therefore better teachers from the start.

Helping others is why I went into teaching. It's important to make a difference

I love teaching. I think it's one of the most important and influential jobs one can have.

Innately I feel a responsibility to share what I have learned on my path as a teacher - a "pay it forward" mentality.

It is my field and I am pleased to help our young teachers. It is like a legacy.

I am committed to helping and love the idea of being a mentor.

I feel true experience is one of the best teachers, so I love offering that to the candidates.

I am very interested in participating in teacher preparation; it is critical for the field.

I'm aware of the changes coming up with Common Core and think it's easier to instill these changes in a new upcoming teacher rather than in some of the older teachers. I find learning exciting and see that same excitement in some teacher candidates. Engaging with them in new ways to implement quality education encourages my own personal teaching.

I come from a long line of excellent teachers. I truly believe teachers change lives.

I do like to observe preparation levels of new teachers.

I feel that each teacher should do what they can to help insure competent teachers are graduating and joining the workforce.

I believe in the future of our children, so I want to see the best teachers teaching them.

I am not sure how taking on a teacher candidate improves the field of education. It is basically trying to help that one person that you are working with. 
\#27 Please explains how teacher candidate content knowledge influences your decision to mentor teacher candidates.

If they are prepared and knowledgeable about our curriculum, standards, etc. it makes the transition easier for them and the teachers.

I expect candidates to come to me comfortable with the content.

It's the luck of the draw but in Elementary I assume content is there but sadly is not even at the fifth grade level

I feel it is very important but it does not influence me at this time.

How can one teach another to do something well if the teacher is not knowledgeable or can't transfer the skill? Impossible. Therefore, the candidate must master the content.

None

Experience and sharing it is important for future teachers.

At the secondary level, content knowledge is essential to student success. I have had some teacher candidates who had a poor knowledge of their subject matter, which has made me leery of accepting a teacher candidate. I also have found that teacher candidates only want to teach to their strengths. Unfortunately, CSOs dictate what subject matter is taught per grade level, not personal preference.

Again, I work in elementary education. They need to have a good fundamental in all areas.

The science teacher candidates have always been well rounded and knowledgeable. I am a product of Moutaskis and I think the Science professors are top notch!

Knowing that they are knowledgeable and can figure out what they have to do let me know that they will do well in their job

Teacher candidates should have a good grasp of the content area before setting foot in a classroom.

If content knowledge is lacking, we cannot teach it during the teacher candidate experience. That should be addressed before students are placed.

I like to learn from the candidates; therefore, they provide me with tools for my classroom.

It doesn't -- they will not have the requisite content knowledge to teach. I didn't, so why would I expect that of these teacher candidates.

No brainer...they should know is by now...can be limited in areas. But should have basic concept

A teacher must be knowledgeable in his/her content area, in order to adequately instruct and explain. 
The better they are prepared the better they will work with the students

Again, I am not interested in teaching an adult elementary concepts. If the teacher candidate made it through college without knowing basic skills, we have problems.

Having a teacher candidate that has a sound understanding of content knowledge is always a plus. This makes the entire teacher candidate process smoother and gives the teacher a sense of being able to let go in the classroom.

I want the teacher candidate to know how to plan a lesson and deal with middle school students. A broad knowledge of the content is necessary, but in Social Studies, it is difficult to know all of the content!

N/A

In the social studies the wide range of subjects taught creates a situation where most candidates can't possibly have the knowledge needed to teach everything they may be required to teach

The more the mentor knows coming in the easier the transition will be

I have seen all extremes over the years. I do not want someone coming to my classroom with limited subject area knowledge.

Teachers and students teachers must have content knowledge to teach students!

Again, I should know what's going on

Most of my recent candidates have been knowledgeable, but I have had a few in the past that did not know the material.

Teachers who have been passed along often are not willing to learn enough to teach.

Honestly, it gives me an opportunity to keep my own teaching fresh and authentic.

I teach general science, so there is quite a bit of information that is required in order to simply explain the content in a way middle school students will understand. However, not only do candidates need to have a strong base knowledge, they must be able to continue to look information up. The fastest thing a middle school student will notice is whether you know your stuff or not. It's one of the first things they test you on and many times their respect depends on your success.

They must be knowledgeable, and they must study the material before teaching it.

Unfortunately, there are teachers in the classroom who are lacking the proper content knowledge. Some candidates do not see the overall content knowledge (not just their subject area) as important.

All have come prepared. 
Again, you never know what you will get. Sometimes teacher candidates come with just about everything they need to teach. They just need a place to practice. Others have come with poor English skills and very little content knowledge. They have to be taught most lessons before they can teach it to the students.

Content knowledge is important and the mentoring process helps the candidate to get in the field experience as well as bringing to the mentor new ideas the candidate may be able to present.

I don't mind giving suggestions and helpful hints, but it is not my job to teach them their content.

At times it seems that what the teacher candidates learn in their classes are not always what is going on in the classroom now, so it is good for them to come out and see.

This is a somewhat important influence to me, but not extremely important. If a candidate has a base knowledge of what a standard is, (what students are expected to learn, understand, and do) and what assessment is, everything else can come along the way. I am not familiar with 9th grade biology content, but can teach it if I work from the STANDARDS and can assess the student's knowledge of that standard. I have had a teacher candidate without this background knowledge and it took LOTS more time to mentor them through the process of planning. I'm not sure all those involved in teacher preparation at the college level have this basic understanding of standards and assessment.

I have a lot to share and I enjoy my job in Special Education

A teacher should be an expert in their content knowledge, be able to access a wide variety of resources, and have a passion for it (IE, read and learn more independently).

You have to know the material you are presenting to the children.

It's important that everyone be on the same page. I sometimes believe I may be too tough on the candidate or asking of them something they're no prepared for. We as teachers need a class or professional development so we can work with MU. A paper with instructions doesn't give you all the necessary info you need.

Absolute must ... I don't have time to teach them content as well as "teacher skills"

N/A

Content knowledge does not play a big part in my decision. Most of the students I have worked with in the past have a good foundation of knowledge. The content knowledge is also something they can add to as they learn the specific grade level.

My experience is that they are well prepared.

Very important - mentor teachers do not have the time to teach content to the teacher candidates, particularly at the secondary level - if we have a teacher candidate or two in a row lacking in this area, I know I am less interested in taking another one into my classroom as my high school students must come first. 
Most of the teacher candidates are prepared with content knowledge but they frequently have great difficulty breaking it down systematically so that the student in the classroom can understand the information and build on it.

I find it exciting to be able to learn the latest from the teacher candidates that come into the classroom. You are able to pick up on technology, curriculum, and activities for the common core that you would not have access to without attending school yourself.

The teacher candidates should have the knowledge prior to coming into teaching so that I do not have to worry about teaching the content.

Content knowledge is the most important factor for teacher candidates (at the high school level, anyway). I want a candidate to know more than my students!

Content knowledge is easily reviewed before delivery in the classroom; however, the method of delivery, the person that the candidate pictures as a good presenter of knowledge to a classroom of eager and hungry students is the problem. This is a process that takes more than a six weeks period of teaching. Many candidates have not found they are a force that pulls the eagerness of education from a student. They believe the students are there and ready to learn whatever comes out of their mouths. Very rarely do we find a student that realizes that our job of enhancing their employability skills will help them in any prosperous endeavor they attempt.

No influence.

I am always hopeful that candidates have sufficient knowledge to come into the classroom and "get to work."

Learning new ideas

If I have a candidate that lacks and in-depth knowledge of economics, history, or government then it is my duty to teach them as well as my students.

Because my MA is in English Literature, I have high expectations when it comes to content knowledge. I am not bothered by a student who doesn't know what assonance or consonance is but I am bothered when the student doesn't bother to find out.

I have been satisfied with the content knowledge my past TCs have had when working in my classroom.

Again, if they don't have the knowledge of Cabell County mandates and programs, it makes it difficult. In addition, frequently teacher candidates come with ideas, lesson plans, etc. that Moutaskis wants them to have but that don't work or aren't needed in reality.

I feel that I have a strong knowledge of my content and I feel that is very important.

That content knowledge will increase with teaching.

I want to help them understand different techniques that students learn.

I can help fill the gaps. 
I feel MU students are well prepared with content knowledge before entering local schools for interaction with teachers and students.

I usually am not concerned about the candidates knowledge of their content- being able to manage students and effectively teach is another skill

They need content knowledge to be able to teach.

I want to make sure they know what they are teaching.

Many new candidates are weak in content; need extra prep

Content and skill is a large part. However, I believe that teaching skills are vital to communicating information to people so they can retain and develop. Content is easier to develop than teaching skills.

Ability to present knowledge in an age appropriate way is more important though it is important

Often clinical students have a fresh approach to the content. I enjoy brining that into my classroom.

It is very important to know curriculum, but this is something that is gained along the way.

Do they know their content well enough to have confidence in teaching it to teenagers at the high school level?

I believe the teacher candidates are well equipped within their content knowledge when they come to me. I teach history so I need to make sure these students are teaching unbiased facts/events to my students.

I like to know the teacher candidate has knowledge about the field they are entering.

I have always appreciated the content knowledge teacher candidates come in with.

The last few candidates I have had were excellent. They understood the content well.

The student candidates seemed to well inform and willing to learn. Also everyone at Moutaskis is willing to listen if we see a need.

New teachers must have a passion for history and must instill that in the students. To do that they need to have master the content.

They should somewhat be familiar with the curriculum

Again - it has become more of an issue the last decade or so. My issue has been the lack of overall "general" knowledge and global intelligence, no so much specific content knowledge. I also think newer candidates can sometimes rely on technology as a "gimmickry" solution to difficult learning strategies. I use/embrace technology in my classroom often when advantageous to the process - not as a tool to disguise my own lack of prep or laziness. 
I believe that MU adequately prepares their students both in the classroom and out in the real classroom before student teaching begins.

As a 1st grade teacher, our content isn't too challenging. One area I do feel needs to receive attention prior to Moutaskis Students entering our classrooms is their grammar. I've been surprised at the grammatical errors I hear come out of the mouths of Moutaskis Students, even those at the level of student teaching, who are placed at our school.

I have only had positive experiences with teacher candidates.

I enjoy having teacher candidates because it keeps new and fresh ideas in my own classroom.

Believing that the candidates sent to us are prepared makes the decision to help them much easier.

Each candidate is different, some with more content knowledge than others - hopefully are, for those who fall short, I can steer them in a direction that will help them catch up, or begin. It has no bearing on my decision as to whether I take on a mentoring situation.

They usually know the basics but are getting no practical instruction on developing or teaching a "practical" lesson plan.

The teacher candidates I have worked with have been able to keep me abreast of changes in teaching methodologies I can try with me students. I allow them to teach me as well and helping them learns what I have experienced in teaching for 18 years.

It does not influence me

To teach effectively, one must have in depth content knowledge to teach effective and rigorous lessons.

Integration of instruction is returning in full force and it can be difficult to implement if you have never experienced how to do so.

As stated earlier, my students were doing clinical and weren't responsible for content knowledge. I think it is the university's job to insure the students have the knowledge needed.

Most are well prepared.

For the most part, content knowledge isn't a problem. Helping teacher candidate's work on the delivery of that content is where they need help.

A student having a gap in an area does not bother me. The student not wanting to become better and fill the gap does bother me.

Same

It is exciting to see new ways to teach.

It gives me a chance to see and hear anything that I am not having heard in new teaching techniques. 


\section{Q:\#28 Please explain how teacher candidate professionalism influences your decision to mentor teacher candidate}

They should always behave professionally. Our profession is not respected well as it is, so we need to encourage professionalism in our profession.

I expect candidates to come to me prepared to exhibit professional behavior.

I'm disappointed by the lack of professionalism...cell phones should be an absolute no and dress is too casual

Again, very important but this is not an influence for me right now.

The candidate must dress and act professionally. Again, educators are role models for children.

Candidates must be ready to bridge the gap from student to professional when performing clinical experiences. Lack of professionalism (tardiness, dress, ill prepared, etc.) reflects poorly on not only the candidate, but also the college in general.

Like what I'm seeing from recent candidates.

Professionalism is important, but it is not an issue that I dwell on before accepting a teacher candidate. Plus, I feel that the perception of professionalism is extremely subjective, especially with such varying school cultures and environments.

Most students we have had have been very professional.

For the most part, candidates are very professional.

Knowing that we can trust them around young students help ease our fears. Watch them interact with and instruct those shows us that they may become great teachers

Teacher candidates should have the demeanor to be in the classroom and interact with students; this means they should not be overly timid or overly aggressive.

We are professionals and want all incoming teachers to dress, behave in a professional way.

Professionalism is expected.

It's a frustration in terms of how MU students seem to think they have a solid understanding of education at the age of 21.

MU should include mentors more in issues...not just a weekly 5 minute chat with supervisor 
Professionalism can be learned, but it is key to make sure that a teacher's actions are always in the best interest of the students.

The more professional the better

I don't want to have to tell them not to wear belly shirts, gnaw on gum, use inappropriate language, or mistreat children. I expect a teacher candidate coming out of Moutaskis University to behave as a professional because I have seen how they are prepared.

Teacher candidate professionalism greatly influences the overall decision to continue with teacher candidates. From confidentiality to dressing appropriately, having a sense of professionalism coming in makes a mentoring teacher's job much easier. We don't expect the candidates to be perfect, but do expect them to be willing to accept change.

I don't want to have to deal with students who are late to school, dress inappropriately, etc.

All of the teacher candidates that I have had have been very professional. It has not been problem.

A bad experience with an unprofessional candidate can make a supervising teacher consider not taking teacher candidates.

I think professionalism has a wide range of definitions; I want to see how they interact with students.

I would want to see candidates come in to the classroom with professionalism and great work ethic. We influence young minds every day and need to do that in such a way as to not deter the learning process.

They must be professional!

They have to be respectful of your space as well as the program in general

Professionalism has only been a problem with one candidate.

This is the primary issue for me in refusing a teacher candidate this year or for asking one that's been placed to leave. The last teacher candidate was terrible, placed on a plan of improvement and really refused to do anything! What a nightmare! My school paid for it with the lack of knowledge for our own students progressing to the next level.

Anyone who walks into my classroom and interacts with my kids must be professional. You can relax and have some fun with them, but you must always remember you are the teacher and not the friend. Education is not just about the content. We as teachers are teaching the proper way to interact with others, many times through observation. In addition, I have seen firsthand the teachers who lack some professionalism. The kids think they are a joke.

It is embarrassing to me when the candidate is unprofessional, making me less likely to accept another one.

We are professionals. We expect the candidates to act in a professional manner.

All have been professional. 
In student teaching, it is important for candidates to learn and model professionalism to prepare them for their own career.

You just never know. I guess I have more teacher candidates who come with these skills than not. Too many bad ones in a row could change my willingness to keep mentoring.

I believe professionalism is very important for the candidate to not be thought of as just another student in the classroom and school environment especially in the secondary level.

Like a musician, if they already know the basic notes, then they can learn the song.

The teacher candidates I have seen always are very professional and that makes it even better to work with someone like that.

I have not had an issue with teacher candidates being unprofessional. I know many other teachers have. I think MU has done a better job of explaining expectations and holding accountable for professional behavior/dress/work ethic.

We need someone to lean on and give feedback to throughout our careers in education

It is huge. Nothing turns me off more than someone who is late, shows up unprofessionally dressed (dress clothes please - no jeans, shorts, tee shirts, etc.). Please do not roll in looking like you just came from bed after an all-night frat/sorority party.

I think if you dress and act professional, the children will show you respect.

It's very frustrating when a teacher candidate is late or dresses inappropriately etc.

Professionalism is what I see most student have an area of weakness.

n/a shouldn't it be expected?

I am proud of my profession and expect teachers and candidates to exhibit professionalism.

Most have performed professionally

Very important! It is very difficult to mentor another adult who has little or no professionalism - inappropriate dress or too friendly with my students, tardiness, absenteeism etc. definitely influences my decision to mentor another candidate.

I try to exhibit the professionalism needed to conduct a classroom. Some teacher candidates want to be a friend to the student. You must maintain a professional but caring relationship with the student.

I feel it is very important for teacher candidate to be professional in all ways during their experiences in the schools.

I expect the candidates to behave professionally and if they come to me without those manners then they need to be reevaluated. 
Professionalism is not a character that one puts on with their morning wardrobe. Professionalism is a core value that is enhanced by our modeling; it will influence the language used, demeanor, coworker relationships, and ethical treatment to all encounters. By the time, a teacher candidate reaches 22-23 years old it should be well developed.

No influence.

I am always hopeful that the candidates have a professional attitude.

Best way to learn is from experience

If one is unprofessional, it will make me less likely to accept them in future.

Professionalism is so linked to personal responsibility and integrity. There are many professionals who are not professional in their behavior so I feel it is essential to guide teacher candidates in this regard, also. It is a big factor in my decision to "pay it forward."

I have had no trouble with this so far, so I have little worry on this matter.

Candidate professionalism is a huge factor in my decision to mentor teacher candidates. I have had four observation students in the past year (not all were from Moutaskis), but one just didn't come the last day, and one didn't show up on any regular schedule and was obnoxious when she was there. In the past year at my school, one had to be told to go home because what they were wearing was inappropriate and one had to leave our school because of inappropriate language in the classroom. So yes, professionalism counts a lot.

When a candidate is less than professional, it is my job to help them become professional.

I want to show and tell them the do's and don'ts of a teaching role with students.

Every teacher must be professional.

I am a role model for candidates in professionalism; dress and behavior.

The MU teacher candidates with whom I have had experience have been very professional.

It is impair ant to me I treat my peers and students with respect and I have an old-fashioned philosophy about good manners

Very important. They are a reflection of our school and classroom.

They need to act like professionals.

Very important

Very important. This can make the experience so much more difficult for everyone. 
it is important

I have extremely high expectations for our clinical students. If they do not walk into the school as a professional, they will most definitely walk out a professional.

They must always act as a professional, children model what they see.

Primarily dress code and use of their phones, appropriate language. I want my candidate to be respected!

This is important to me because teachers need to show professionalism when dealing with the students, parents, and community.

Professionalism is extremely important to me. I do not a teacher who thinks they are there to be the student friend. The teacher is the adult and is there to do a jog.

If a candidate is not reliable, he/she will be more trouble than they are worth.

The teacher candidates seem to understand how important professionalism is so I have not ever had a problem with this.

The field of education must be kept at a high level.

This is most important especially because I look really young, I feel like professionalism has went out the door now with these younger kids. Promptness and showing up and dressing and acting appropriate are very important.

Discussed earlier. Again - some candidates seem extremely immature.

Once again, I believe that MU urges their students to practice professionalism, so I am not worried about my candidate(s).

The only thing that would truly worry me about teacher candidates is their lack of classroom management skills.

At any level of clinical experience, this is very important. I consider correct grammar to be part of that professionalism, as these people are role models for our students.

You have to remember that many teacher candidates are fairly young. Not too far off from their high school years. I think it's important to remember that sometimes it takes time to develop an awareness of why professionalism is important.

I believe that if a teacher candidate wants to be treated as a professional they must act as one from day one.

I have had very professional candidates and those who have not real desire to teach. This process helps let those candidates see the amount of work and commitment is truly necessary.

Again, each candidate comes to the room with unique professional qualities - if they are not on target for teaching, they will be 
addressed.

None Teacher candidates usually come with the desire to be a good teacher

The teacher candidates I have worked with have had great professional skills and often come back to my school to work with other teachers who have requested them.

I have expectations of professionalism in myself as well as the candidate

That's not a problem if the lead teacher is a positive role model and reflects often with his/her peers.

Teacher candidates need a model of professionalism, especially when dealing with difficult situations. Emotion cannot rule over logic and adherence to

I have had two clinical students. I had problems with both. One was immature and the other had issues with dress (short dresses) and not being professional with things like setting up our initial meeting, follow through with returning my calls, and not calling when she didn't show up. Then she dropped out.

Everyone can continue to learn professionalism. We learn together.

Teachers must be above reproach; teacher candidates should exhibit these characteristics and appreciate the importance of being professional.

It's an awkward position to be placed in when a candidate is not professional.

Professionalism is an extremely important part of the teaching profession. Too many people out there want something for nothing.

Teachers are influential in and out of the classroom. A teacher MUST have high morals and a work ethic.

Same

I like to see teacher candidates come in ready to do their best. 


\section{\#29 Please explain how you view teacher candidates' ability to plan and deliver lesson plans as it pertains to your decision to} mentor teacher candidates

Their training and willingness to learn and take initiative to be actively involved in the classroom make it easier for both parties.

They are not always realistic...classroom teachers do not have the time to write everything out as required if teacher candidates. There seems to be more emphasis on the written lesson than on the implementing and knowledge of the lesson

The same, important but not an influence right now.

Candidates must have a strong working knowledge of planning and delivering the standards. They MUST know the standards before they can begin to create rich instructional plans for student achievement.

The key here is delivering. The best plans are worthless if the candidate cannot teach them. Thinking on their feet combined with an understanding of what the goals of the lesson contain is paramount.

Have been impressed with work ethic of candidates.

Again, this is a very important issue to consider before accepting a teacher candidate. I would like to say that this is the most important issue to consider since it directly impacts student learning, but rarely are sample lessons/unit plans submitted to me to preview before I accept a teacher candidate. After having a bad experience with a teacher candidate, who was lacking in her content knowledge, and consistently constructed poor lesson plans, I did not accept a teacher candidate the following school year. Therefore, poor lesson planning and instructional delivery can taint my perception of teacher candidates and impact my acceptance of another.

They are ready to go when they enter the school.

It is very important to have a candidate that can plan and follow his or her lesson plans. I only had one negative experience with a candidate on my team not keep up with his lesson plans.

Show that they can dot their I's and cross their t's. All educators must be able to do the paper work

A plan is very important as an outline as to where you are going and what and how you plan to achieve your goals. But more important is thinking on your feet and implementing your plan in a clear, fun, organized way. I want to help them to learn how to do that.

Student's teachers should have a basic grasp of how to set up a lesson and deliver it on their own without copying it from instructional materials such as pre-made plans on cods.

I do not want to be their teacher, only their mentor, so this should be taught before they enter the school to student teach. I realize it will need refinement and the best teacher is experience.

As long as the candidate is willing to learn, I'm happy. 
Basic prep work...keeps them on a path///some just find item son internet...more practice with last minute changes

Candidate teachers are over prepared to write lesson plans, and correcting errors in the delivery of lesson plans is one of the duties of the mentor teacher.

Good planning usually has good results

I feel that MU goes a bit overboard at times with lesson planning requirements but I understand that a teacher candidate must learn the process. Those extensive lesson plans I see teacher candidates writing, in my opinion, are unrealistic to the actual day-to-day classroom experience.

The ability to pan and deliver lesson plans is very important for the teacher candidate.

This is very important! However, I am willing to help them and point out any problems or improvements.

It is helpful if they are able to do this well but if not it is the supervising teachers responsibility to instruct them in this area.

I do not believe one can really understand these processes until they do them.

If they can plan and deliver with little help then there is less time spent going over those issues

This is very important and we can only take the word of your university that the teacher candidate can do that. We have no preconceived knowledge of this aspect.

This is probably the most important ...they must have a roadmap to know what they are doing... then they have to have the skills to implement the plan in ways that reach students!

By the third tier they should know what they are doing

MU should not tell teacher candidates that they only have to teach a five-day unit during the second half of their student teaching. They should be required to teach full time, so that they can get a real feel for what it means to teach for a living.

I don't mind this so much, if it's a weakness. I think that I can help teacher candidates with this if they're willing to work.

My only comment here is that the lesson plan requirements expected by the university can become cumbersome when we are trying to align my plan format with that of the university.

I am always going to be there as a resource for my candidates, even when they leave my classroom. However, they have to be able to hold their own and roll with the changes. Candidates need to understand that it is perfectly fine to ask for advice or guidance, but it needs to happen before the lessons are taught. And it is perfectly normal to run out of stuff to do or have a moment for the lesson plan crashes and burns. However, the candidate has to be able to roll with it and turn it into something that works. Sometimes you have to scrap is and do something different and this is the time to learn where you have backup. 
If they are unable and unwilling to submit plans as well as carry them out, they have no business in the classroom.

All are willing to change and adapt.

Some need more help than others need. I have to be willing to give more guidance when it is needed. I do not want my students to suffer.

Again, this allows the candidate to put into action all of the training received.

Plan, to (typo) makes the job so much easier, you can spend more time tweaking the lesson than just figuring out what to teach!

Just like anything else it takes practice, so in the beginning there is always room for improvement, but they try and become better and better.

While this is extremely important to teacher success, I believe if this is a weakness in a teacher candidate- that is my job to help mentor them to become better. I will say it is difficult to mentor BOTH areas, I've had some teacher candidates who can plan effectively, but has trouble delivering them. I can step in, model, give feedback on that area and it can be improved. I've had other teacher candidates who struggle with planning, but have more of a natural ability to deliver content. I can also help in that area. I don't expect a teacher candidate to be proficient in both of these areas right away, as long as they are willing to learn and grow through feedback and reflection. While it hasn't happened, I do feel comfortable sharing with MU if a teacher candidate does not express the ability to do either and should not continue.

Most come prepared and they bring new ideas into the classroom

Huge. While there are things we can teach them about how things work in the real world, they should come with a large toolbox and skill set.

Children respond to candidates that are excited and interested in them. The teacher candidate should deliver the lessons in many different ways.

Things in education are changing very rapidly right now with the new Common Core, it is now we should be working with the colleges so they can be sure they are changing with us. Starting this year we will be implementing new concepts and instruction and it is a very different delivery of instruction and we need teachers coming out of Mu that can teach this very as well.

Delivery of a lesson plan is something that evolves.

Absolute importance ... I can't go back and re-do what they've covered per time restraints and material required by WVDE

I expect a teacher candidate to be able to deliver lesson plans, but also understand they will require guidance and assistance at times.

Most have that ability and are committed to using it.

They need to be prepared to develop a unit plan and individual lesson plans - real-world lesson plans not necessarily the university 
version...they need to be able to show differentiation and flexibility - when this is missing, again, it takes too much of the mentor teacher's time and affects my decision.

Usually the teacher candidate moves quickly with the information and loses the attention of the slower moving students. Lesson plans are frequently made to follow a specific format but then the candidate has trouble adjusting the lesson to fit the needs of the students that he is working with.

I think that the teacher candidate should be able to plan and deliver the lesson plans that they make. I feel it is important for them to make clear concise plans without a lot of fluff so that it's easy to follow and gives me the information needed to show they are teaching appropriate skills and common core goals.

I think that I should help with the planning and delivering of the lessons. The candidates should observe, collaborate, and then work on their own.

Lesson plans and delivery are paramount in teacher success. A lesson plan should be a guideline for the teacher to use to keep on tract. The plan should be the canvas that creativity has designed. A teacher then uses the plan along with their engaging delivery to encourage participation by the students. The skill of encouraging hands on, vocal, and personal involvement by the students. These skill sets develop separately but must be delivered as one in the classroom.

* I presume you mean, "plan and deliver." When deciding to mentor, I do not have any knowledge of the candidate or his or her skill level so I don't really understand what this is asking.

In the past few years, candidates have been more ready to plan and deliver lesson plans than they used to be. I don't know if that is because they are taught better at Moutaskis or if it is the access to so many resources on the internet.

Helpful in giving ideas and getting new ones

I expect the teacher candidate to be able to effectively deliver a lesson that is meaningful to the students and one that deals with important topics. If they cannot differentiate well then schools won't be successful, so I need to help them figure out how to do so.

I expect them to plan well and to deliver with a bit of nerves, at first. I want to help the teachers become reflective about their teaching and their plans. In our field, we have to monitor and adjust constantly.

I think the lesson plans Moutaskis requires the TCs do not in any way reflect lesson plans actual teachers must write. However, I have had no trouble with TCs ability to write and deliver lessons.

It might be the number one factor that influences my decision. It doesn't matter how beautifully written their lesson plans are if they aren't able to deliver them and manage the class at the same time.

Some plan well. Some do not. I try to help them learn to plan.

The planning and lesson delivery will improve with time, trial, and error. 
Very important. It sets the foundation for how they perform for years as an educator.

They come with varying levels of abilities. Everyone has a certain style. I am an example for them.

In my opinion, MU teacher candidates have always been well prepared and able to deliver excellent lesson plans that engage the students.

Right now I don't know how much the candidates know about Common Core, Quad D, and Gold Seal Lessons etc.

Makes it easier to work with them.

Candidates have GOT to be able to do the basics.

Need to be practical in their approach

Very important.

I am not concerned if they can hit the ground running or not, we can hone that as needed.

I think planning lesson plans are important but ridiculous lesson plans hamper teaching

I expect that a clinical student will not have a large understanding of running a classroom, which is what makes my decision to take them. I want to help shape and mold them.

It is very important to be able to have control to deliver lessons to kids. It's important to show candidates different models of how to do so.

Have they practiced before? Have they put time into 'observing' to know some activities that work /don't work?

A teacher candidate who knows how to lesson plan and develop a lesson with the big picture in mind saves valuable time.

Lesson plans are important but new teachers need to be able to adapt. Things change quickly.

Because common core is so new we have to scrounge around for unit materials but the teacher candidates are not thrown by this at all and we can work together to create them.

They seem to do fine.

Since most of the teacher candidates do, a good job at both of these it does not add a lot of extra work to my day.

Not everyone or anybody can teach. They must be trained to manage their classroom and its time. 
They are learning I am very patient and willing to give constructive criticism.

Their planning is often sufficient. I believe many candidates could benefit greatly from more "practice" actually presenting lessons before standing in front of 25 kids. In a public school.

I'm excited to see my candidate in action and offer positive and negative feedback when needed.

Because I have Moutaskis Students in their first clinical experience, I understand that these skills will be in the early stages.

I have been in close contact with many Moutaskis University teacher candidates, candidates over the last 13 years. I have also worked with teacher candidates through WV Birth to Three. I think that the challenge that I have seen the most is the new candidate's ability to think on their feet. To use the lesson plan as the guide, but be able to capitalize on teachable moments or dive into students' interests. Sometimes I think they stick "too" much to the plan.

This is very important. If a teacher candidate has little to no ability to prepare and deliver lesson plans, then I am required to spend much of my time teaching the candidate how to do this. My wish for teacher candidates is to already have this ability. I want to be there to give suggestions and guidance. When I have to spend a lot of time showing them how to do things they should have learned in their classes then I feel that I should be compensated for the extra instruction I must give. When candidates come prepared, I can enjoy my role as mentor and facilitator.

The lesson plan format from the college is extremely detailed and unrealistic. While attention to content standards, objectives, a varied methods are important, the amount of writing required on the college level is excessive.

It is all a learning process - if they don't have the skills - hopefully through their experience they will have been guided.

I wish MU would teach the candidates to use the adopted texts and create plans that are not pages long. I stress source, page numbers, and directive word such as: read, explain, listen etc., and only list supplies not readily available in the classroom.

The teacher candidates who have worked with me have been able to plan and implement lessons with students after they work with them and understand their educational needs.

Finding your teaching style takes practice. Trying and putting in your best effort makes a difference in your delivery

This is the hardest part to watch. Most new teachers don't teach with the enthusiasm that I would like to see because they are nervous. I try to bring their "performance" level out and make them more comfortable in order to do so.

I enjoy planning lessons and I appreciate any opportunity to work with a teacher candidate on finding his or her personal planning and delivery style. I don't want to produce a replica of me but I want to support a candidate in discovering and honing a style based on the candidate's strengths.

My students did not do lesson plans.

The planning they are required to do base on Moutaskis Expectations is more than I've ever seen. They are well prepared. 
This is one thing they absolutely should be able to do. This can be taught and learned if one is paying attention.

If candidates are not prepared, I will not work with them. My job is to help them with their plans, not teach.

Every teacher plans and delivers differently and even more so depending on the content and the students' needs that are factored into the equation. As long as a teacher candidate is willing to look at what needs to be taught and considers how to best deliver such content to the students in the class, I'm open to them doing what needs to be done. I expect to see their plans before hand and then discuss their delivery afterward for the chance to praise and encourage them.

I feel this is what I can help them develop. The teacher candidate must have a desire to improve.

I believe I do a decent job in that area but like to observe methods of new teachers.

A teacher candidate needs to do the best they can. It does not matter if the lesson was successful the first time, but they need to be prepared to deliver their lesson.

A teacher candidate's ability varies with the candidate and how much they have worked with elementary school children. It will always be a work in progress. If they had it all together, they wouldn't need me.

Their training and willingness to learn and take initiative to be actively involved in the classroom make it easier for both parties.

They are not always realistic...classroom teachers do not have the time to write everything out as required if teacher candidates. There seems to be more emphasis on the written lesson than on the implementing and knowledge of the lesson

The same, important but not an influence right now.

Candidates must have a strong working knowledge of planning and delivering the standards. They MUST know the standards before they can begin to create rich instructional plans for student achievement.

The key here is delivering. The best plans are worthless if the candidate cannot teach them. Thinking on their feet combined with an understanding of what the goals of the lesson contain is paramount.

Have been impressed with work ethic of candidates. 


\section{Q 30: Please explain how the potential opportunities to sharpen your own skills influence your decision to mentor teacher candidates}

It is nice to see what is being taught to the newer generation of teachers.

Teacher candidates allow me to view my classroom from the outside in and give me the opportunity to make improvements.

The good ones bring fresh ideas

This would be an excellent opportunity to improve my own skills.

My instructional practices must accommodate the learning of all my students as well as model those practices for teacher candidates. I also enjoy learning strategies and practices from the candidates as well. The candidates usually bring something to the table that is notable.

Every day is an opportunity to learn. I feel that lessons can come at any time and from any one.

It keeps me up-to-date on current technology and professional development.

Instill the idea of a lifelong learner.

I enjoy the collaboration process and feel that I can always learn something new that will benefit my kids.

Not at all.

We can all learn from each other. Some of the lessons they do are great! The mentor is able to learn best practices from the students.

I like learning from the candidates as much as I like mentoring. I can always be better than I was the year before.

You're not too old to learn, we watch and see how younger teacher react and interact with the students

Not a large concern to me.

Working with another individual is usually a plus. Everyone has something to contribute and everyone has something to learn. It is a win/win situation.

This is one of the biggest influences. I get to learn for "free"!

Usually re-energized ability to try different things outside the box...we all get stale

Instructing, observing, and evaluating others can help you reflect on your own performances. 
Prepared candidates keeps me on my toes

Teaching is the best opportunity for learning.

Professional learning opportunities are always a plus, but should not be mandatory.

This is very important. I always learn from my teacher candidates or am reminded of something that I knew but has forgotten or got out of the habit of using.

Anything to educate me more is beneficial.

I learn from some of their ideas which I can continue to use

I'm always open to new ideas and learning, but this does not play a big factor in my overall decision to serve as a mentor teacher.

We can always learn something new.... I sometimes see the up and coming trends in action.

It keeps us old teachers on our toes

Little to none.

As I stated earlier, it keeps my teaching fresh and authentic.

You never truly learn something until you have to teach it. I learned so much just from having someone in my room looking to me for guidance on what to do. I had to make sure I had reviewed and brushed up on my strategies. And my candidate even taught me a couple new ones.

Very often, they are great with technology, and I use that as an opportunity to learn.

I am always open to new knowledge. Sometimes, the candidates can teach me a new technology skill, or even bring a new outlook to an old skill.

I am always looking for ways to improve.

It is an added bonus. Fresh ideas, seeing things in a different way. I think I do better job as a teacher when I know I am modeling for future teachers. If I don't show them my best skills every day, I will be teaching them to do less than their best.

It absolutely sharpens my skills!

I believe that anytime new concepts and ideas of teaching are shared the teacher becomes a better educator. 
Teaching others helps us learn too. Basic concept! New Ideas!

With teaching veering is always changing, so when a teacher candidate comes to my classroom they can show new ways to do things.

You really learn something when you have to teach it. I enjoy how much mentoring teacher candidates keeps me on my toes. I'm not sure there are explicit opportunities for all to take part in if they are mentoring a teacher candidate?

It keeps me up to date

Teacher candidates have the ability to reinvigorate a classroom, bringing new strategies and ideas.

I enjoy learning and trying new things with my students.

I do enjoy watching the young candidates because they do have the drive and ability to amaze me with their energy of delivery.

Forces me to reflect and recognize my own weaknesses vicariously through them

I am still learning every day. The TC has a lot to teach.

I think having a teacher candidate in the classroom makes me reflect even more on my practices.

I have learned a great deal about especially technology and how students react to others.

A nice perks sometimes, but not always a part of the package...so it really doesn't affect my decision.

My application of new technology has been greatly enhanced by working with teacher candidates. They have helped me to present old lessons with a new technology approach.

I love the idea that they bring newness to the classroom with new technology ideas, teaching methods/styles as well as resources and exciting new ideas

There should be a lot of reflection when working with a candidate, which would help with my own skills.

I feel that I can always benefit from watching/helping someone else teach.

A teacher candidate is no different in a classroom than the students when it comes to sharpening your own skills. A good teacher learns delivery techniques, compassionate understanding of a student's opinions or set ideas. Opening their and our minds to each of these possibilities is how we grow as lifelong learners.

Opportunities to sharpen my own practice are always available and I am open to such opportunities. 
The candidates bring new ideas to me and I love getting fresh, new activities to use.

Learning every day from new experiences

They don't play much of a factor, but if I see something that I like I will try to incorporate it.

Working with other teachers makes me more aware of my own strengths and weaknesses as a teacher. It inspires me to try new technology, or to work more collaboratively with other teachers in my building, too.

I think it is good for a veteran to be exposed to younger teachers and the new theories/strategies they bring to my classroom.

Honestly, none. I continue to engage in professional development opportunities that sharpen my own skills. Mentoring teacher candidates is something I would like to do to "give back," but I don't see it as an opportunity to sharpen my own skills.

I always learn something when I act as a mentor.

It will make me put forth the effort to model what they are expected to do as a teacher in a high school setting.

Teachers are always learning g new techniques and strategies.

I find this not to be an issue.

Every year, Reading block students amaze me with new activities. I use many of their activities in my classroom.

Reflection is always good and I find that when I am ex [; aiming my teaching techniques and philosophies it is a great way to reflect and also learn from the candidate

I need to stay up to date if I am going to mentor new teachers. They should see and learn best practices.

It does keep me on my toes.

I am always open to new ideas and students coming out of college seem to have many ideas.

Refresh my skills when I show others options

It keeps us on our toes to have someone observing and learning from us. It reminds us to do our best all the time.

I do not think it does sharpen your skills

A fresh pair of eyes can always bring something to my teaching process. I enjoy letting people in to share what they would do. 
I am always attending PD to understand any new teaching style or activity

Newer teachers can keep me up on the latest trends so I don't get set in my ways.

I like to stay up to date with current teaching strategies, technologies, and ideas in my classroom. Sometimes I learn new things from my teacher candidates and that is very exciting.

I try to take advantage of any professional development that I am offered.

It makes me aware of staying focused on time and behavior management. I enjoy learning from the candidates as well.

Being a mentor allows me to keep up with many new ideas in education.

It does not.

It helps me to stay focused and on schedule

Though personal growth is beneficial, the emphasis needs to be on the candidates. I honestly do not need lectured to about how mentoring new teachers is somehow an intrinsic motivator to my own development and growth.

I'm excited to see and hear new ideas and techniques that the teacher candidate has to offer.

When a Moutaskis student is in my classroom, I am more likely to try a wider varied of activities with my students. This probably due to the fact that I have an extra set of hands during that time. For this reason, I feel that these experiences benefit my students.

I am a perpetual student. MU student since 1997 LOL I use any opportunity to learn!

I would enjoy mentoring teachers more if I had opportunities to sharpen my own skills before doing so. I feel that I would be better prepared myself to give the candidates what they need.

While I do learn new methods from the teacher candidates, that is just an added bonus to the process, not my major motivation.

I like new ways of doing tasks - if there is something new to learn that is being taught, I am eager to see and hear.

I look forward to learning the technology skills that the young propel have. Every student teaches me something that I didn't know. However, I feel that the students are poorly prepared on the smart board, responders, and IPod.

I always learn something new from my teacher candidate.

I learn as much from the teacher candidates as they learn from me. 
I get to see different styles of teaching that I may want to incorporate in my classroom. We never stop learning

I like the challenge.

I am constantly taking and teaching classes, networking with colleagues, and attending conferences and workshops. I think it is important to "spread the wealth" to other educators. Working with teacher candidates is just one way I can extend any knowledge I gain.

New ideas, and enthusiasm and energy.

Mentors should always be great models. It is a great way to do some serious self-assessment.

I learn as we go new skills and management.

Looking at new developments in education keep me current.

Mentoring teacher candidates helps keep teachers up to date with new research and methodology.

I like bouncing ideas off others; it helps me think through some of the processes of how to deliver my content. Having a teacher candidate is helpful in this area of teaching. I also learn from their approach to teaching as well, seeing what works with my students that I may not have tried yet.

I love all opportunities to sharpen my skills.

Again, I can learn from new teachers.

Every experience is a learning experience.

Teacher candidates come into the classroom with fresh ideas and enthusiasm, which helps keep me on my toes!

This is a big factor for me. 


\section{\#31 Please explains how the lack of compensation influences your decision to mentor teacher candidates.}

It doesn't.

This is why I must be certain I have the time to take on the added responsibility since I receive no compensation; it's done for no other reason than to be helpful.

It would be nice to be compensated but that not the reason I do it

I feel that teachers who mentor should be compensated. That being said, some teachers would participate only for the money and may not be the best mentors. We need some very to be sure that the best teachers are mentors and that they are paid for it.

Compensation...observing the metamorphosis of a new teacher transpire. It is my duty to contribute and invest in the future of education.

None

Doesn't

Sometime of compensation would certainly be nice, even something simple like a $\$ 25$ gift card to Office Depot, etc. However, compensation does not affect my decision to mentor teacher candidates.

Not at all.

Doesn't affect our decision.

I am paid other ways. I haven't been in education long enough to say, "We used to get paid for taking teacher candidates!"

You get nothing but the satisfaction of watching the start of a new era of teachers

Not a large concern to me.

It is extra work and I would like compensation.

It doesn't.

We do most of the work...and receive nothing at all now. MU makes some big $\$ \$ \$$

It doesn't.

Doesn't bother me a bit 
It does not.

We can pay a football coach a six-digit income, but we can't give mentoring teachers a hundred bucks? What do you value at MU?

I don't feel that compensation plays into my decision.

It would be nice to be paid, but it really doesn't factor into my decision.

Does not influence

It makes more reluctant to take on the added responsibility, and it makes me feel less obligated to do all of the red tape associated with mentoring.

It would be nice if you would consider giving a stipend to the mentor teacher. I'm neutral on this aspect.

Sometimes it is very time consuming especially when you are the person that spends most of the time with the teacher candidate.... The university supervisors come in two maybe three times at the most and receive compensation. I know that the student's need the experience and will probably always be a mentor however maybe giving a gift certificate for a dinner or coffee shop might make us feel at least a little appreciated :)

It doesn't, but it would be nice if we did

I think it is terrible that the supervising public school teacher does all the work, but gets no compensation for it. The university supervisor visits maybe 2-3 times and gets a full time salary.

None

Not a strong factor.

It would be nice to get more than just a bag, because you work one on one with the candidate. I saw my host teacher and worked with them more than I did my Moutaskis supervisor. However, I'm not going to stop doing it just because I'm not compensated.

It would be nice to have some monetary compensation.

I don't care about being paid. It is part of what I do.

It doesn't matter if I am compensated or not.

It was nice when we were paid, even though it wasn't much. I liked when we were given a token gift. Now we get no compensation. However, my students benefit from having two teachers instead of one. 
As teachers there are many things, we do not for compensation and helping to develop future educators should be one of these.

It really doesn't but it does make you feel a little more appreciated in a profession that doesn't pay a lot compared to other professions.

This has not influence on me. If I am needed to help, I don't mind to help.

I've never been compensated, so I don't expect it. I do believe in professionals being compensated for their time, but if that were to happen, I would think there should be some accountability. If anyone is allowed to mentor a teacher candidate, it is possible for it to be manipulated in a way that the teacher doesn't have to take more time to mentor, but allows the teacher candidate to work for them.

I am a professional. I work very hard to help mentor and mold future teachers. Teachers are always asked to work extra without pay. There is not another professional field where employees are asked to work free.

This has not been an issue

It does not.

You can be compensated in other ways. Seeing the teacher candidate become a successful teacher is a wonderful feeling.

I think we as teachers offer something the colleges can't and that is real world experience. All teachers would tell you that while content are important of course, it's the dealing with children and delivery of that information that can't be learned from a textbook. We are an invaluable resource and we should be compensated accordingly

major deterrent ... we play an integral role in mentoring these candidates and while a thank you is appreciated it truly doesn't compensate for the risks we take professionally especially as testing becomes more and more critical . . also it is a HUGE time commitment outside of the school day for both candidate and mentor . . time away from my family that they are more ok with if I receive compensation outside of a thank you that really doesn't register or mean anything to them . . all my kids know is that Daddy's gone working with a teacher and not here with me

We spend a lot of time with our T C. A compensation would say lot.

The lack of compensation does not influence my decision.

I consider it a professional obligation and expect no compensation.

Honestly, it was not much of stipend as I recall, so not a factor for me - however I have heard other teachers complain about this...

When I have had teacher candidates, it requires more work for me because my planning time cannot be used for planning and evaluating student's work. I end up taking more things hem to do and then explaining my plans or going over the teacher candidate's plan during our preparation time.

I do not expect compensation for the experiences that teacher candidates bring. Of course it would be nice, but that has not bearing one 
way or another that I accept teacher candidate in my class

I am really not worried about the money at all.

I feel the "free labor" of having someone help out in my classes in compensation enough. Any time they are teaching a lesson is time I have to observe and less time I have to plan! Getting experience is what it's all about!

The field of teaching is wrought with the lack of compensation for the work we do. I am well paid when I know I have helped to create an understanding in a student how to be an effective teacher. Knowing they will become a good teacher in the classroom and take the place of one that has forgotten the novice zeal of a beginning teacher, therefore giving good experiences to future students is the good will payment that does more than compensate. I must also say helping a person decide the classroom is not a place for them has its rewards as well.

I do find it unfortunate that a mentoring program is expected without compensation.

Pay was always nice, but not the most important factor. We have gone from getting $\$ 35.00$ per candidate to getting a free t-shirt, to getting a Marshal flash drive and bag, to getting nothing.

Doesn't matter to me

It makes me agitated and less likely to take them. I don't like to take candidates because I have my workload increased after they leave in order to pick up the slack and I have to evaluate the candidate, but receive nothing in return. I know that in the past teachers were paid for this.

The payment is helping another teacher and learning from him or her, in turn.

I have no issue with not being compensated for taking a TC.

I truly believe we should be compensated. It's a lot of work, stress, anxiety, etc., and while I know it influences some people's decision whether or not to mentor a teacher candidate, it's not what influences my decision. I would like to be paid to do it, but I have such a hesitation about taking a teacher candidate that I'm not sure money would influence me to do it.

I believe that it is just part of the job.

I am not doing it for monetary gain, but to help someone become a good teacher for our children.

It doesn't.

It doesn't. I mentor new K teachers in my building very year with no compensation.

I feel a commitment to help teacher candidates on their journey to become excellent teachers. I teach because I love children and want the best teachers possible for our future students. 
It doesn't

Would like to have it but I understand why we don't get it anymore. May take less because of it.

I'm a teacher. That comes with the territory, unfortunately.

I am not concerned about being compensated. I believe we help each other.

It would be nice to receive compensation; but obviously not mandatory

Well, the time it takes is considerable sometimes. In addition, some teacher candidates are not good candidates and make it more difficult. The fact that we get nothing monetary when we are wing asked so often to give so much is disappointing. Especially after you have a difficult candidate and got nothing but grief from the experience. If there were any compensation, it would help motivate others to participate.

It's a given that our input and opportunity for experience is invaluable. We understand that the role of a mentor is rarely done for financial gain.

I think it shows what Moutaskis University thinks of teachers. They pay professors, tutors and supervising teachers but not the teacher whose classroom the teacher candidate is in. I do not need the money but it seems disrespectful.

I'm a gluten for punishment, so doing it for "free" is okay with me. I just enjoy the experience.

Really. I'm a teacher. Money is not the issue

No influence

This does not really bother me. Would it be nice to be paid a little extra? Sure. However, I feel that what I am doing makes an extreme difference and that is good enough for me.

I think it is important that teachers be compensated for their time. Mentoring is very difficult, but I would still help even without pay.

It does not. This is something I believe in.

It would be nice to receive compensation, but I know students need a place to practice. Therefore, my room is open.

Compensation would be nice but not really a factor.

When I first mentored a teacher candidate, I got paid 60.00 and attended a luncheon at MU where I was personally thanked. As the years went on the luncheon was cut. Then the money was stopped. Now I get a MU computer bag. Do you see anything wrong with this picture? I am sure tuition has not decreased. 
It doesn't matter but this is the only state I worked in that does not compensate

This is a MAJOR influence. No explanation needed.

As with any other professional position, teachers need to help other teachers. None of us go into this profession with a mindset of getting rich.

Because I supervise students who spend only 35 hours in my classroom, I don't feel that I should be compensated in any way. For those teachers who supervise teacher candidates, because they have such a great responsibility, I feel that they should be compensated.

Feel free to pay me! It's not a problem...but pay would be nice!

Lack of compensation does not influence my decision until I have to do more instruction (instruction I feel they should have from their classes), as opposed to only serving as mentor.

I think the advantage of a lower workload for me while the teacher candidate is actually teaching makes it worthwhile.

None of us are in this for the pay - it just isn't there.

No influence, however I think it is wrong to charge full tuition for only Fri seminars and two classroom visits. Moutaskis is making a lot on teacher candidates and should pay the supervising teachers.

Does not affect me

I view my working with new teachers as a professional need and I will always do all I can to make the profession better for students.

Compensation would be appreciated due to the quantity of paperwork and observations. I would be more willing to take a teacher candidate with some type of remuneration.

Doesn't bother me at all.

I would prefer to be paid simply because I put a lot of time into my candidates. I consider it an apprenticeship. However, I will take candidates regardless.

I think teachers should be compensated for having teacher candidates. It requires a lot of extra work and planning.

It doesn't, but it would be a nice perk.

There is no compensation and while that is typical, it may help with added expenses such as materials the teacher candidate might like to use but cannot afford on their own. 
Teacher candidates need to experience the real life situations that they cannot get in a classroom.

It does not.

I'm not at all concerned about this.

It requires a lot of time and effort to mentor students. The small compensation is not a reason to do it. Treat us like professionals with more pay.

I look at all that is being paid for now days and this is a very important part of a student's preparation for teaching. Why this is not as important as the college professors is my question?

Does not influence my decision.

N/A

I don't even think about it. I am a teacher. That is what I do! I teach! 


\section{Q33: Please discusses the reasons that you would or would not consider mentor a teacher candidate.}

Sometimes, the mentor teacher is given none or unclear objectives from the professors as to what are expected of the candidate. They also often do not seem to know about the current programs, curriculum, and standards that are currently used in the classroom.

I have mentored a candidate before.

I say yes with some resistance I would not take a teacher candidate in the fall when I'm trying to establish my classroom

I would not mentor right now because of time and commitments. I may consider mentoring in the future to improve my own teaching skills.

I believe that teacher candidates experience the reality of education in my classroom. I offer support for the candidates and allow them the advantage to invent, design and create innovative lessons to integrate curriculum to meet the needs of our students.

The only reason I need is that I now feel that I a skill set that will help candidate become the teachers they need to be for the future.

Want to do my part to encourage new teachers in order to keep talented educators for the benefit of our students.

I think being in the classroom is the best thing for a teacher candidate. This gives them the real life experience to see what they are going to be doing for the rest of their lives.

Please see previous responses as they detail why I would and why I would not accept a teacher candidate.

I would be happy to mentor a student. I do not understand why I am unable to mentor a former student. In the past 3 years, I have sent at least 3 students into math education. I have worked so hard with them to make them the best that they can be. If I am not allowed to mentor them, I really don't care about mentoring anyone else.

Just to make an impact in the lives of students.

I believe in what we do with PDS and STEPP and I will continue to offer my time, knowledge, and services to shaping tomorrow's future educators.

I would consider it because it is important for new teachers to have experience in the field with someone who is willing to help them in a constructive and positive way.

Right thing to do

I want to help develop and mentor teachers.

I will be mentoring elementary teacher candidates and I am retired and I do not have a classroom. 
I have had a bad experience with Moutaskis's candidates in the past, but would be willing to give the school another chance.

To help them attain their degree and certification.

I enjoy mentoring.

Maybe...hoping to see changes that never come

I went ahead and filled out this survey because I'm interested in being a mentor teacher in the future, but I have not had that opportunity yet.

Same as question one

I feel it is a duty to share experiences and help new educators in the field.

I support my university and am investing in the continuing program of student teaching.

As a principal, I see the importance of starting a teacher out on the right path and this gives us the opportunity to change the future of education.

I would mentor a teacher candidate for the chance to collaborate with a colleague, to help a new teacher, and to learn more myself.

A great networking tool.

I feel it is my duty.

I would not if I have to change my schedule within my day

I qualify my answer ruby saying that the university needs to review its paperwork and the criteria for the different levels of clinical experience. The paperwork and evaluation forms need an update. The forms are not clear as to the duties for each level etc.

Teacher candidates must have clinical experiences... I am a teacher... It is my duty professionally to make sure they have the same opportunities and support that I received as a Teacher candidate!

I would not only if the regular school year was going poorly

Lack of work ethic in the teacher candidate makes me want to quit taking teacher candidates, but I have had some who work hard. I keep taking candidates and hoping for the best. If teachers like me won't take them, they don't get to have a true learning experience that will make them better teachers.

I might but going in there would an understanding that persons refusing to make simple lesson plans with notes would not be allowed to 
be in front of my own students. If that meant a different placement or a low grade that will be OK with me.

It allows me to contribute to the continued development of education as a whole.

I want to have inurnment ken the future of teaching.

As stated above, I feel that I should give back to the university that helped to train me. In addition, I enjoy working closely with the Music Department.

Pass along my love for teaching. Pass along things I have learned.

I enjoy helping future teachers and giving them tools to make the transition to their own career easier.

As long as the good out ways the bad, I will keep working with teacher candidates. If it comes to a point when I feel my students are being negatively affected more than they are being helped, I will stop taking teacher candidates.

Yes because I learn from them new techniques \& ideas (there is always something new in education). No because sometimes I have time constraints like two years I renewed my National Boards, this year I am finishing my Masters in Administration and next year I am piloting a Zoology course at our school.

The teacher candidate I have seen or that have been in my classroom has always been helpful.

As long as MU holds teacher candidates responsible for professionalism and work ethic, I would continue to mentor teacher candidates. I would not mentor a candidate if there were not an open relationship between the university and school.

I would consider mentoring a teacher candidate because without mentors the future of teaching would not be very hopeful.

It gives them a chance to be in a real classroom not just on paper. It gives both parties the chance to reveal ideas that work and share ideas that don't work.

It is a professional obligation.

I love to share my joy for teaching with others.

I do enjoy their energy and willingness to go beyond the norm. I like the lessons that have these influences because my students truly benefit, however; with the time and effort we as mentors offer these candidates, I believe we should be compensated!

I want to help students.

Because I have had terrible experiences in the past and it's a burden to put up with kids who don't want to be there 
See previous positive responses

It is my duty to give back.

It has been an overall positive experience in the past, and I feel the professional obligation to help teacher candidates become teachers, and I learn from the experience.

It is a necessary service; I enjoy working with candidates and feel I can give them a positive and realistic experience in my classroom!

I enjoy working with people interested in the teaching field. I gain new insights into teaching methods. I like to Shao teacher candidates that the classroom is only one part of the teaching job description. You must work with parents, counselors, and other teachers to be successful with your job. The job is not over at 3:00pm.

I enjoy the experience in my classroom for an opportunity to learn new teaching methods and ideas. I love the idea that they bring with them countless ideas, activities and resources and love to share my knowledge with others to help them to become the best teacher they can become.

I feel that we should all be willing to give our time to help our future coworkers.

I will not this year because I feel I am too "Green" to be of much help (except in the "what not to do" department). In the future, I would love to mentor teacher candidates. It's always nice to have a fresh pair of eyes in any situation.

I believe in the future and I believe in collaboration and helping in any way possible.

I have retired, but if not, I would still love to mentor those candidates.

I enjoy working with others giving ides and getting new ideas

It is important to help improve the quality of education even though accepting candidates is frustrating, especially with no compensation.

I was so fortunate to have an excellent mentor teacher and to work with other inspiring teachers throughout my career so I will always consider doing the same for another teacher as long as I teach.

A summary of my previous responses should suffice as an answer for this.

Too much stress, anxiety, work, hassle in a job where I'm already stressed, anxious, and overworked.

I enjoy sharing my knowledge in the subject matter and classroom management.

I want to be a part of helping someone become a good teacher. 
I graduated from Moutaskis and am willing to help anyway I can.

Every teacher candidate deserves to have a good student teaching experience.

I enjoy the interaction with MU students. I enjoy watching their growth in the weeks that they are at our school.

I think I have already given reasons as to why I would mentor a teacher candidate in answering the previous questions.

Important for future teachers. Someone has to take them.

As I said earlier, I feel like it's an obligation.

This is my first year in a new grade and I will be feeling my way for a while.

If I had a major project of my own, I would not take one. However, do not have any currently.

Possibly, I would. I had a difficult time helping with the last one. It was a horrible experience. However, if my chairperson delegates to me to take one on then I would. I would like to help someone and to have an influence on people.

These teacher candidates will be in the classes and I want the students to have good teachers.

I believe I would enjoy being able to help someone as they prepare to be a teacher and work with them. I

I LOVE working with people, especially young college students that can bring a new perspective to things.

I can't think of any reason

I have not mentored yet but if it goes well and candidate is strong, I would be open to it in the future.

The only issue I have is with time constraints. It would be so great if a teacher candidate would have the ability to stay after school so I could help mentor them but I understand they have to work often times.

Everyone needs helps sometime. We all were at this place in our career once upon a time.

I enjoy working with the Moutaskis Staff and young adults.

If public school teachers do not help MU, who will?

Addressed earlier.

WV needs GREAT teachers, and anything I can do to help those teachers stay here, I'll do. 
I would mentor a teacher candidate, but I feel that I have not yet taught long enough to be a good mentor.

I hope to continue mentoring those students who are doing their level 1 clinical experience.

It's fun to work with new teachers. They have different ideas and that keeps things interesting. I enjoy providing guidance a new teacher.

I would mentor a teacher candidate that had met the requirements of the college and was well prepared. I don't like to be the one that says a teacher candidate is not prepared to be a teacher. I feel that the candidates should already be weeded out before they get to the student teaching level of experience. I feel more collaboration with the supervisory teacher from Moutaskis would also help in being a mentor. More support would benefit both the candidate and me as a mentor.

I have retired this year.

I have no reasons to not do it.

I enjoy working with them.

I love working with new teachers. I find them to be very helpful and I learn so much from their ideas.

Making a difference and a positive experience is important to me.

I would agreeably become a mentor teacher to assist teacher candidates with adjusting to the teaching profession as well as to build a stronger foundation of ideas and exposure to what is taught in teacher preparation programs.

I want qualified and knowledgeable teachers in the classroom.

As stated above I consider it a professional obligation to support any new teachers. Teacher attrition rates are high and I would like to guard against losing good quality educators.

I enjoy having a teacher candidate.

My current teaching schedule is heavy with AP and honors students. I do not want to give these students to a teacher candidate.

I would consider a teacher candidate in order to help another individual be the best teacher they could be.

I have good experiences so far, but the thought of having to give negative scores bothers me.

I have many responsibilities right now. I teach an AP course, which is very time consuming. The new math programs are also very time consuming. 
Again, I have no reason not to mentor a new teacher.

I believe I have answered this question above.

I enjoy it! 